\title{
A revised infrageneric classification and molecular phylogeny of New World Croton (Euphorbiaceae)
}

\author{
Benjamin W. van Ee, ${ }^{1}$ Ricarda Riina ${ }^{2,3}$ \& Paul E. Berry ${ }^{2}$ \\ 1 Black Hills State University Herbarium, 1200 University Street, Spearfish, South Dakota 57799, U.S.A. \\ 2 University of Michigan Herbarium, Department of Ecology and Evolutionary Biology, 3600 Varsity Drive, Ann Arbor, \\ Michigan 48108, U.S.A. \\ 3 Real Jardín Botánico, CSIC, Plaza de Murillo 2, 28014 Madrid, Spain \\ Author for correspondence: BenjaminvanEe, bvanee@uwalumni.com
}

\begin{abstract}
Croton (Euphorbiaceae) is a large and diverse group of plants that is most species-rich in the tropics. We update the infrageneric classification of the New World species of Croton with new evidence from phylogenetic analyses of DNA sequence data from all three genomes. The relationships of species that were previously placed in conflicting positions by nuclear and chloroplast data, such as C. cupreatus, C. poecilanthus, and C. setiger, are further resolved by adding the nuclear EMB2765 and mitochondrial rps3 genes to the molecular sampling. Analyses of $r p s 3$ reveal an accelerated rate of evolution within Croton subg. Geiseleria, the only one of the four subgenera that contains numerous herbaceous, annual species. We provide morphological descriptions, species lists, and a key to the 31 sections and 10 subsections recognized in the New World. New taxa that we describe include C. sects. Alabamenses, Argyranthemi, Cordiifolii, Corinthii, Cupreati, Luetzelburgiorum, Nubigeni, Olivacei, Pachypodi, Prisci, and C. subsects. Cubenses, Jamaicenses, and Sellowiorum. Additional transfers are made to the ranks of subgenus, section, and subsection. A total of 712 species of Croton are currently recognized for the New World, with 702 of them assigned here to section.
\end{abstract}

Keywords Croton; EMB2765 exon 9; Euphorbiaceae; infrageneric classification; molecular phylogenetics; New World; rps3; taxonomy

\section{- INTRODUCTION}

Croton L. (Euphorbiaceae) is a characteristic genus of dry to moist vegetation in the tropics and subtropics worldwide, and its species can usually be recognized in the field by their pungent odor, stellate or lepidote pubescence, clear to colored latex, and leaves that turn orange before dehiscing. It has long been considered one of the "giant genera" of the angiosperms (Brown, 1883; Frodin, 2004) and was last tabulated by Govaerts $\&$ al. (2000) to consist of over 1200 species. Its large size, great morphological diversity, and broad distribution have made it challenging to study, even with molecular data.

Webster (1993) reviewed earlier work on the infrageneric relationships of Croton worldwide and proposed a system in which he recognized 40 sections. Although he provided a concise description for each section as well as a key to the sections, he only listed representative species for most groups, with the result that a majority of Croton species remained unplaced to section. Unlike Müller (1865, 1866, 1873), Pax (1890), and Pax \& Hoffmann (1931), Webster (1993) did not attempt to organize these sections hierarchically. The first molecular phylogeny of Croton and tribe Crotoneae by Berry \& al. (2005) helped define the limits of the genus and made an initial evaluation of the monophyly and relationships of the sections recognized by Webster (1993). The only change in the circumscription of the genus that emerged was the removal of Croton sect. Astraea (Klotzsch) Baill. and its return to generic status. The recircumscribed tribe Crotoneae resulted in seven genera: the large
Croton sister to the monotypic Brasiliocroton P.E. Berry \& Cordeiro, these sister to a clade comprised of Astraea Klotzsch and the sister genera Acidocroton Griseb. and Ophellantha Standl., and all of these sister to a clade composed of Sagotia Baill. and Sandwithia Lanj. (Berry \& al., 2005; Wurdack \& al., 2005). Together, the other six genera of Crotoneae comprise fewer than 30 species, compared to over 1200 in Croton.

Subsequent molecular phylogenetic work on Croton has focused on specific groups within the genus, such as $C$. subg. Moacroton (Croizat) B.W. van Ee \& P.E. Berry (=C. subg. Quadrilobi (Müll. Arg.) Pax in Engl. \& Prantl; Van Ee \& al., 2008), the Jamaican species of Croton (Van Ee \& Berry, 2009a), C. sects. Cyclostigma Griseb. (Riina \& al., 2009), Cuneati (G.L. Webster) Riina \& P.E. Berry (Riina \& al., 2010b), Luntia (Neck. ex Raf.) G.L. Webster (Riina \& al., 2010b), Heptallon (Raf.) Müll. Arg. (Van Ee \& Berry, 2010a), Pedicellati B.W. van Ee \& P.E. Berry (Van Ee \& Berry, 2011), and Cleodora (Klotzsch) Baill. (Caruzo, 2010). There has also been recent monographic work on $C$. sects. Argyroglossum Baill. (= C. sect. Lasiogyne (Klotzsch) Baill.; Gomes, 2006), Cleodora (Caruzo, 2010), Crotonopsis (Michx.) G.L. Webster (Van Ee \& Berry, 2009b), Cyclostigma (Smith, 2002; Riina, 2006), Eluteria Griseb. (León Enríquez, 2007), Heptallon (Van Ee \& Berry, 2010a), and Lamprocroton (Müll. Arg.) Pax in Engl. \& Prantl (Lima, 2006; Lima \& Pirani, 2008).

We estimate that approximately two-thirds of the species of Croton occur in the New World, with the other third scattered across the Old World. Webster (1993) admitted to providing a 
more cursory treatment of the Old World groups and species of Croton compared to those in the New World. We have the same bias, although we are making major strides in understanding the phylogenetic relationships of the nearly 150 species of Croton from Madagascar and neighboring islands in the Indian Ocean (Berry \& al., 2009; Haber \& al., 2010). Consequently, we focus this study on the New World species of Croton. Our goals are to expand the molecular and taxonomic sampling of Berry \& al. (2005), recognize and name new infrageneric taxa, recircumscribe others, provide an update to Webster's (1993) sectional key (excluding the Old World sections), and place to section as many of the New World species as possible.

\section{- MATERIALS AND METHODS}

Taxonomic and molecular sampling. - Berry \& al. (2005) were unable to sample 11 of the 40 sections of Croton recognized by Webster (1993), and these were specifically targeted for the molecular analyses presented here. We also targeted New World species potentially representing a distinct section, whether suggested by morphology or by prior molecular evidence (i.e., Van Ee, 2006; Riina, 2006). Nine Old World samples were included as placeholders for the estimated 400 Old World Croton species, which form a monophyletic clade in the molecular analyses completed to date (Berry \& al., 2005, 2009; Van Ee \& al., 2008; Riina \& al., 2009; Haber \& al., 2010). Each molecular sample is represented by an herbarium voucher specimen (Appendix). Overall, we analyze 112 accessions representing 108 ingroup Croton species, of which 99 are New World species. This represents $100 \%$ of the New World sections that we recognize, and $14 \%$ of the 712 New World species of Croton that we currently recognize. It is important to note, however, that molecular sequence data are available for many more species of Croton than are presented in this paper, both published and unpublished. These are being used to develop species-level phylogenies of the larger clades or sections, and to verify the sectional delimitations proposed here. To date, we have completed studies on Croton sect. Cleodora (Caruzo, 2010, 15 of 18 species sampled); C. sect. Cyclostigma (Riina \& al., 2009, 23 of 41 species sampled); C. sect. Cuneati (Riina \& al., 2010b, 5 of 11 species sampled); C. sect. Heptallon (Van Ee $\&$ Berry, 2010a, 9 of 9 species sampled); C. sect. Luntia (Riina $\&$ al., 2010b, 6 of 19 species sampled); C. sect. Moacroton (Van Ee \& al., 2008, 7 of 8 species sampled); and $C$. sect. Pedicellati (Van Ee \& Berry, 2011, 8 of 20 species sampled). The molecular phylogeny of Croton by Berry \& al. (2005) includes 26 species beyond those used in the analyses in this paper, and Van Ee (2006) provides 63 additional species, which add substantially to groups such as $C$. sects. Adenophylli Griseb., Corylocroton G.L. Webster, and others. Regional-based studies with molecular data such as Van Ee \& Berry (2009a), or ones focusing on new taxa and their phylogenetic placement (Cordeiro \& al., 2008; Riina \& Berry, 2010; Riina \& al., 2010b) further increase our sampling across the New World species.

The nuclear ribosomal internal transcribed spacer (ITS: ITS1, 5.8S, and ITS2) and the plastid $\operatorname{trn} L-F$ (trnL exon, intron, and 3 ' intergenic spacer) markers employed by Berry \& al. (2005) were supplemented by sequences of exon 9 of the coding low-copy nuclear gene EMB2765 (EMBRYO DEFECTIVE 2765, At2g38770), and by the mitochondrial protein-coding rps3 gene, thereby providing evidence from all three genomes. Samples for which one of the four markers is lacking were included in the combined analysis with the missing sequences coded as missing. The phylogenetic signal within Croton found in other chloroplast markers, such as $n d h F, r b c L$ (Van Ee \& al., 2008), $\operatorname{matK}$ (Riina, 2006), and trnH-psbA (Berry \& al., 2009; Haber \& al., 2010; Caruzo, 2010), has been shown to be highly congruent with that of $\operatorname{trn} L-F$.

DNA extraction, amplification, and sequencing. - Total genomic DNA from silica-dried samples, or from leaf fragments picked from herbarium specimens, was extracted and purified using the Qiagen DNeasy Plant Mini Kit (Qiagen, Valencia, California, U.S.A.). ITS was amplified with PCR and sequenced using the primers ITS-I and ITS4 (White \& al., 1990; Urbatsch $\&$ al., 2000), following the methods described in Berry \& al. (2005), with the exception that the PCR reactions were scaled down from $50 \mu \mathrm{L}$ to $25 \mu \mathrm{L}$. For material obtained from herbarium collections, and for silica-dried collections that failed to amplify in one piece, the region was amplified with two primer pairs: ITS-I with ITS2 and ITS3 with ITS4 (White \& al., 1990). The $\operatorname{trn} L-F$ region was similarly amplified and sequenced as one fragment with primers " $C$ " and " $F$," or in two pieces, with "C" paired with "D" and "E" paired with "F" (Taberlet \& al., 1991). Exon 9 of $E M B 2765$ was amplified and sequenced using primers "9F" and "9R" following the methods described in Wurdack \& Davis (2009). Similar to the results of Wurdack \& Davis (2009), EMB2765 exon 9 usually amplified well, and when successful it always yielded single bands. Upon sequencing, some accessions had multiple peaks, which were coded as ambiguities. The mitochondrial rps3 gene was amplified and sequenced in two fragments, using the same PCR conditions as for EMB2765 exon 9, and the primer combinations "F1" with "R1.5," and "F2" with "R1" (Wurdack \& Davis, 2009). Primer sequences and their respective references are given in Table 1.

DNA sequence alignment and phylogenetic analyses. - Forward and reverse chromatograms were edited and assembled into DNA fragments using Sequencher v.3.1.1 (Gene Codes Corp., Ann Arbor, Michigan). Aligned datasets were generated manually in MacClade v.4.08 (Maddison \& Maddison, 2005). All sequences are deposited in GenBank, and species names, vouchers, and GenBank accession numbers are given in the Appendix.

The data were concatenated and arranged into four partitions corresponding to the four loci: nuclear ITS, nuclear $E M B 2765$ exon 9, chloroplast $\operatorname{rn} L-F$, and mitochondrial rps3. The best-fitting maximum likelihood model for each of the four partitions, as well as for all the data combined, were selected using Modeltest v.3.07 (Posada \& Crandall, 1998) using the results obtained from the Akaike information criterion (AIC). Maximum likelihood bootstrap support values were obtained from one hundred pseudoreplicates run in GARLI v.1.0 (Zwick1, 2006). Two independent search replicates were executed for each bootstrap replicate. The substitution models 
Table 1. Amplification and sequencing primers used.

\begin{tabular}{|c|c|c|}
\hline Primer name & Primer sequence & Reference \\
\hline ITS-I & 5' GTCCACTGAACCTTATCATTTAG 3' & Urbatsch \& al., 2000 \\
\hline ITS2 & 5' GCTGCGTTCTTCATCGATGC 3' & White \& al., 1990 \\
\hline ITS3 & 5' GCATCGATGAAGAACGCAGC 3' & White \& al., 1990 \\
\hline ITS4 & 5' TCCTCCGCTTATTGATATGC 3' & White \& al., 1990 \\
\hline $\operatorname{trnL}-\mathrm{F}$ “C” & 5' CGAAATCGGTAGACGCTACG 3' & Taberlet \& al., 1991 \\
\hline $\operatorname{trnL-F}$ “D” & 5' GGGGATAGAGGGACTTGAAC 3' & Taberlet \& al., 1991 \\
\hline $\operatorname{trnL-F}$ “E” & 5' GGTTCAAGTCCCTCTATCCC 3' & Taberlet \& al., 1991 \\
\hline $\operatorname{trnL}-\mathrm{F}$ "F" & 5' ATTTGAACTGGTGACACGAG 3' & Taberlet \& al., 1991 \\
\hline EMB2765 exon 9 “9F” & 5' TGATACCTGAGATTCCGTAACGAG 3' & Wurdack \& Davis, 2009 \\
\hline EMB2765 exon 9 “9R” & 5' TTGGTCCAYTGTGCWGCAGAAGGRT 3' & Wurdack \& Davis, 2009 \\
\hline rps3 "F1" & 5' GTTCGATACGTCCACCTAC 3' & Wurdack \& Davis, 2009 \\
\hline rps3 “F2" & 5' CCCGTCGTAGTTCTCAATCATTTYG 3' & Wurdack \& Davis, 2009 \\
\hline rps3 “R1” & 5' GTACGTTTCGGATATRGCAC 3' & Wurdack \& Davis, 2009 \\
\hline rps3 “R1.5” & 5' CТАТТСССТTТАТСААТТСТССТАТ 3' & Wurdack \& Davis, 2009 \\
\hline
\end{tabular}

selected in Modeltest, and the default automated stop criterion settings were used. Bootstrap analyses were performed on each of the four partitions separately and in combination. In the combined likelihood bootstrap analyses, the data were treated as a single partition.

Bayesian posterior probabilities (PP) were calculated for each of the four partitions and for the combined data using MrBayes v.3.1.2 (Huelsenbeck \& Ronquist, 2001; Ronquist $\&$ Huelsenbeck, 2003). Posterior probabilities were obtained from two Markov chain Monte Carlo (MCMC) analyses, each consisting of four linked chains (heat $=0.02), 10,000,000$ generations, starting from random trees, default priors, and sampling every 10,000 generations. In the combined analysis, the data were divided into four partitions, allowing the program to estimate the model parameters separately for each of the four loci (Brown \& Lemmon, 2007). The best-fitting models for each of the data partitions, and the combined data, were the same as those used in the ML analyses. The burn-in period was estimated by viewing the parameter distributions in Tracer v.1.5 (Rambaut \& Drummond, 2007). After removing the trees from the burn-in period, PP values were obtained by computing a majority rule consensus of the post-burn-in trees from both MCMC chains using the sumt command.

Evaluation of accepted New World species of Croton and their sectional affiliation. - In order to evaluate the number of species of Croton occurring in the New World and to assign them to section, we examined a large body of literature and type specimens. We used the list of more than 800 New World Croton species accepted in the World Checklist of Selected Plant Families (2010) as a starting point in developing a checklist of New World species that we accept, and their subsequent sectional placement. Protologues and type specimens on loan, photographed at major herbaria that we visited, and scanned types on the JSTOR Plant Science website (www.plants.jstor.org) were consulted. In some cases, names that were treated as synonyms in the World Checklist are treated here as accepted species when examination of their types and other specimens showed them to be distinct taxa. We also determined that numerous names accepted in the World Checklist are either synonyms, erroneous citations, or are not possible to verify. For the species that have not been sampled molecularly, we focused on the combinations of morphological characters that distinguish the different sections, and in most cases we were able to assign them to section. Based on this, we developed an avowedly artificial but practical key to the sections.

\section{口RESULTS}

Summary statistics for the data matrices and information about the analyses, such as the substitution models, are presented in Table 2. To assess the relative utility of each marker in addition to the number of variable and informative sites, the well- and weakly supported internal branches recovered in the consensus Bayesian trees from each analysis were counted. These are also expressed as a percentage of the total number of internal branches possible (number of termnials minus 3 ), and the well- and weakly supported branches as a percentage of the total internal branches recovered (Table 2). Well-supported branches are defined as those with $\geq 90 \%$ Bayesian PP and $\geq 75 \%$ ML BS. Seventy-five percent ML bootstrap support was chosen as the cut-off after reviewing the results of the ML BS analyses in which most clades have either $75 \%$ or greater support, or less than $60 \%$ support. In all analyses there are several clades recovered with $\geq 90 \%$ Bayesian PP but low $(<60 \%) \mathrm{ML}$ BS support. Given the potential for having selected the incorrect model, which could create overly high Bayesian PP values, these are treated as weakly supported, although individual clades are discussed (Ronquist, 2004). 
Table 2. Summary statistics for the aligned molecular data matrices and analyses. The number of internal branches recovered is also expressed as a percentage of the total number of branches possible (number of terminals minus 3), and the well- and weakly supported branches as a percentage of the total branches recovered.

\begin{tabular}{|c|c|c|c|c|c|}
\hline & rps3 & $\begin{array}{l}E M B 2765 \\
\text { exon } 9\end{array}$ & ITS & $\operatorname{trn} L-F$ & Combined \\
\hline Number of accessions & 107 & 103 & 112 & 108 & 112 \\
\hline Aligned length & 1861 & 819 & 708 & 1371 & 4759 \\
\hline Variable characters & $361(19 \%)$ & $278(34 \%)$ & $408(58 \%)$ & $474(35 \%)$ & $1519(32 \%)$ \\
\hline Informative characters & $206(11 \%)$ & $175(21 \%)$ & $330(47 \%)$ & $235(17 \%)$ & $945(20 \%)$ \\
\hline Number of internal branches recovered & $58(53 \%)$ & $67(67 \%)$ & $94(86 \%)$ & $60(57 \%)$ & $102(94 \%)$ \\
\hline Number of well-supported internal branches & $23(40 \%)$ & $27(40 \%)$ & $56(60 \%)$ & $23(38 \%)$ & $66(65 \%)$ \\
\hline Number of weakly supported internal branches & $35(60 \%)$ & $40(60 \%)$ & $38(40 \%)$ & $37(62 \%)$ & $36(35 \%)$ \\
\hline Model of nucleotide substitution & $\mathrm{K} 81 \mathrm{uf}+\mathrm{I}+\mathrm{G}$ & $\mathrm{TIM}+\mathrm{I}+\mathrm{G}$ & $\begin{array}{l}\text { SYM+I+G } \\
(\text { hLRT: GTR +I+G) }\end{array}$ & $\mathrm{TIM}+\mathrm{I}+\mathrm{G}$ & $\mathrm{GTR}+\mathrm{I}+\mathrm{G}$ \\
\hline Number of missing accessions & 5 & 9 & 0 & 4 & $\begin{array}{l}\mathrm{N} / \mathrm{A}(\sim 4.5 \% \text { of } \\
\text { total data missing) }\end{array}$ \\
\hline
\end{tabular}

Phylogenetic analyses. - Analysis of the four regions in combination produced the most resolved and strongly supported phylogeny (Fig. 1). Of the 31 New World sections of Croton recognized here, 14 are recovered as strongly supported clades in the combined analysis (Fig. 1). Croton sect. Cleodora is also resolved as monophyletic in the combined analysis, but with less statistical support (100\% Bayesian PP and $73 \%$ ML BS). Of the remaining 16 sections, 12 are represented by a single accession and therefore their monophyly is not being tested. Croton sect. Eluteria, as it is more broadly circumscribed here, is not recovered as a clade, but our results do not reject the hypothesis that it is a monophyletic group. The three remaining sections, $C$. sects. Geiseleria, Lasiogyne, and Moacroton, have one or more members that fall outside of a core clade, and these sections are each discussed individually.

Phylogenetic informativeness among the four sequenced loci. - The two nuclear markers, ITS (Fig. 2) and EMB2765 exon 9 (Fig. 3), contain the highest proportion of informative characters. They provide resolution in roughly the same portions of the phylogeny, and both leave the backbone of $C$. subg. Geiseleria relatively unresolved. The chloroplast trnL-F (Fig. 4) and the mitochondrial rps3 (Fig. 5) markers contain proportionally fewer informative characters and provide roughly equal resolution. However, they differ markedly in where they provide resolution. The $t r n L-F$ region provides resolution in approximately the same portions of the phylogeny as ITS and $E M B 2765$ exon 9, whereas rps3 provides resolution within $C$. subg. Geiseleria and little elsewhere.

Number of New World Croton species and their distribution by sections. - Of more than 800 New World Croton species treated as accepted by the World Checklist, we now recognize 712 species, some of which had been treated there as synonyms. Of these, we assign 702 to sections, albeit with doubts in a few cases. Ten species defy placement to section by reference to their morphological features. Most of these are known from only one or a few collections, and some of them may be resolved to section if further material is obtained. A selection of characters used in the key, such as glands, styles, and sepals, are illustrated in Figures 6 and 7.

\section{DISCUSSION}

Although there is widespread agreement between the four markers in the overall topology and in the support values for most clades, there are a few topological conflicts between the gene trees, mostly between rps 3 and the others. Heterogeneity among datasets can yield misleading results (De Queiroz \& al., 1995), but it has also been argued that simultaneous analyses provide the best explanatory power in phylogenetic inference (Nixon \& Carpenter, 1996). Our combined analysis (Fig. 1) provides the most resolution and support, and our separate analyses (Figs. 2-5) allow for comparison among the different datasets. Our phylogenetic hypotheses, as illustrated by the subgenera and sections labeled on the phylogenetic figures, are informed by all of these, even though none of the phylogenetic trees (Figs. 1-5) perfectly reflect our hypotheses.

An updated classification of Croton based on molecular data. - The classification system presented here attempts to establish monophyletic sections to account for all New World species of Croton. We divide the genus into four subgenera. We describe ten new sections, bringing the number of New World sections to 31,11 of which are monotypic. We also recognize ten subsections, three of which are newly described. This is in addition to two sections and two subsections that were described or recognized recently (Riina \& al., 2010b; Van Ee $\&$ Berry, 2011). The circumscriptions of $C$. sects. Geiseleria and Lasiogyne presented here are broad, and monographic and molecular phylogenetic work is currently underway that may allow them to be further subdivided. Likewise, $C$. sects. Adenophylli, Cyclostigma, and Julocroton are large and diverse groups within which subsections may be recognized in the future. 
Fig. 1. Bayesian phylogram of combined ITS, EMB2765 exon 9, $\operatorname{trnL}-F$, and rps3 data of Croton species and four outgroups. Strongly supported clades ( $\geq 90 \%$ Bayesian PP and $\geq 90 \%$ ML BS) are indicated with thick branches, moderately supported clades ( $\geq 90 \%$ Bayesian PP and $\geq 75 \%$ ML BS) with thick dashed branches, and thin branches represent clades with less support. The number of strong, moderate, and less supported branches is given. Labeled groups represent Croton and the subgenera and sections recognized in this work. Names on the right are sections. Labeled sections that are not recovered as monophyletic groups in this analysis are indicated with an asterisk.
'II!'!"'I = 8 branches

$=58$ branches

$=36$ branches

\author{
(1)
} $\left[\begin{array}{l}\text { lindheimeri- } \\ \text { lindheimerianus }\end{array}\right.$ Heptallon alamosanus. alamosanus
watsonii
yucatanensis
micans
astroites
argyrophyllus - argyrophyllus floribundus . (1) (n)

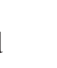

(n)


Fig. 2. Bayesian phylogram of nuclear ITS data of Croton species and four outgroups. For explanation see Fig. 1.

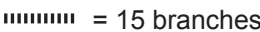
$=38$ branches
C. subg. Geiseleria

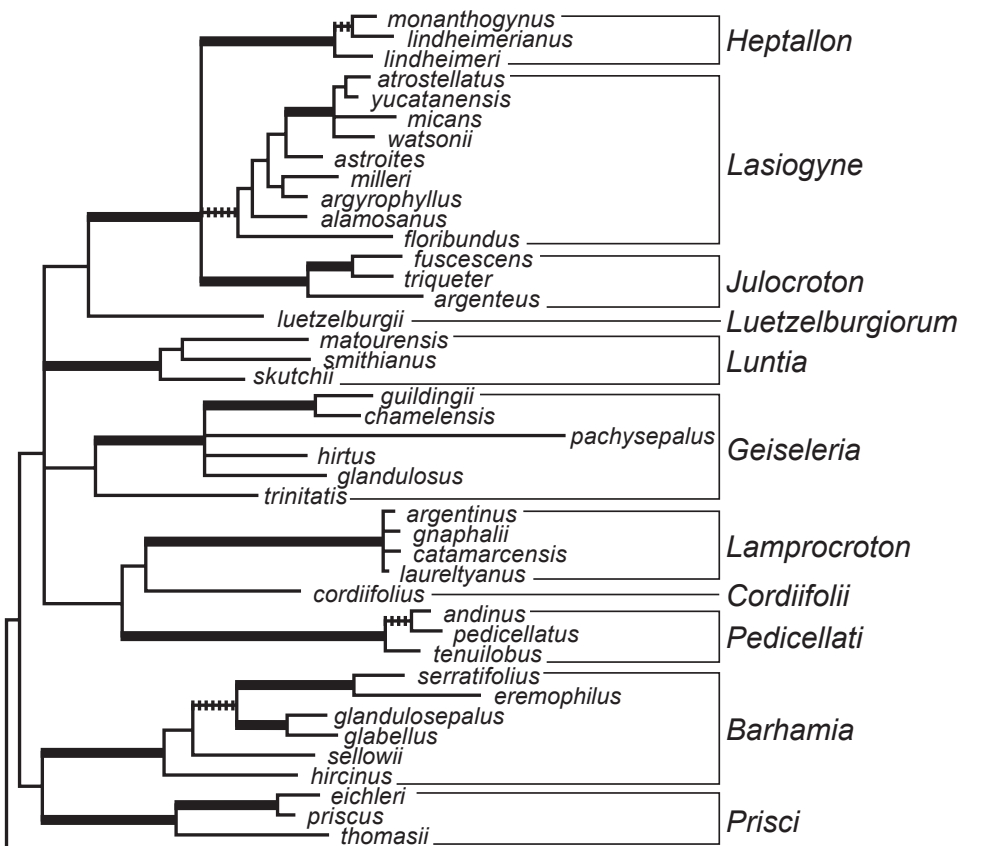


Fig. 3. Bayesian phylogram of nuclear EMB2765 exon 9 data of Croton species and four outgroups. For explanation see Fig. 1.

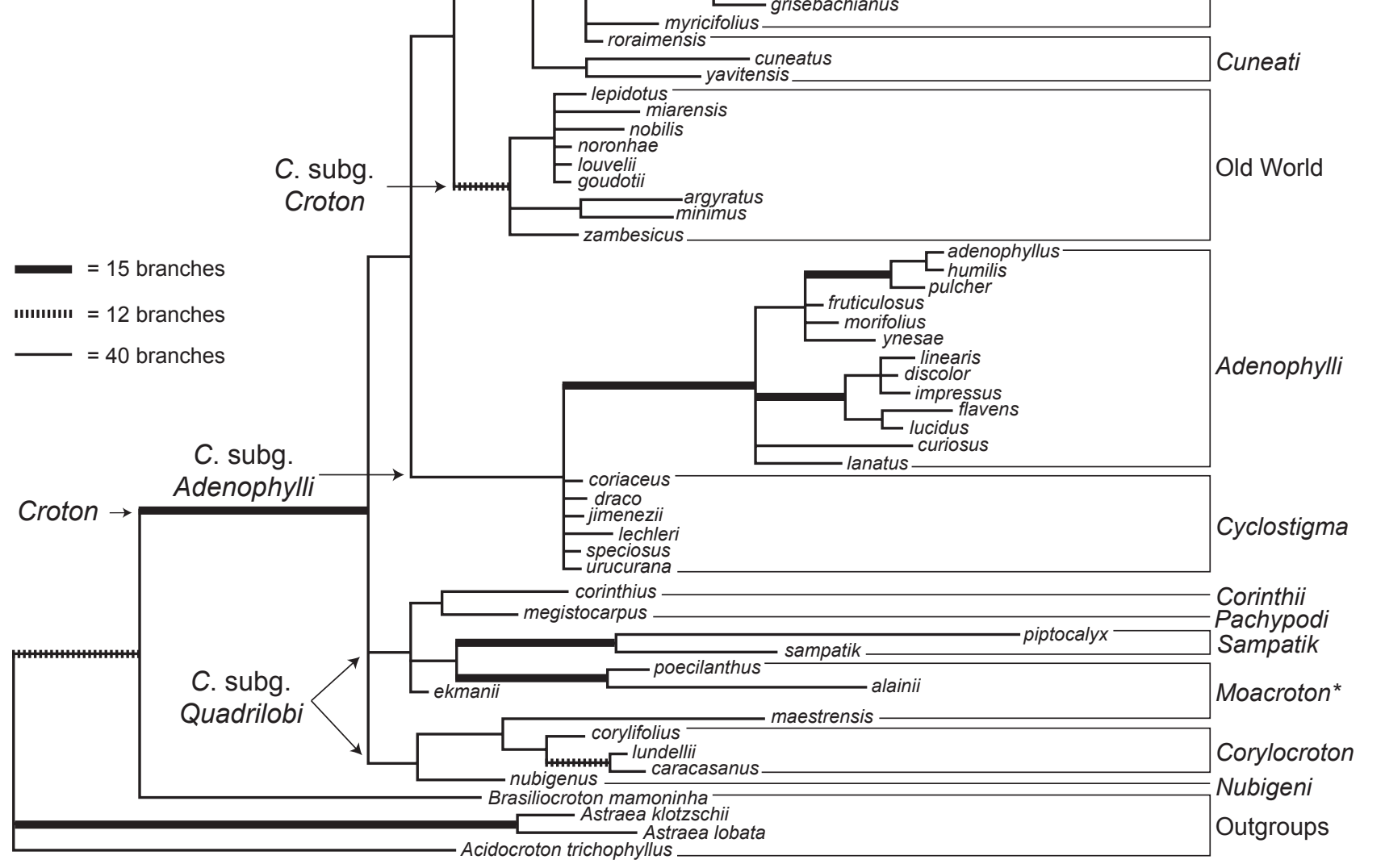

C. subg. Geiseleria

$=0.05$ substitutions per site 
Fig. 4. Bayesian phylogram of chloroplast trnL-F data of Croton species and four outgroups. For explanation see Fig. 1.



C. subg. Geiseleria (excluding $C$. sect. Cyclostigma)

[ lindheimerianus monanthogynus

- yucatanensis

E-watsonii

- micans

- astroites

- argyrophyllus

- atrostellatus

- milleri

triqueter

cordiifolius

tenuilobus

andinus

laureltyanus

- catamarcensis

gnaphalii

trinitatis

trinitatis - guildingii

- hirtus

pachysepalus

serratifolius pachysep
eremophilus

- gland sellowii

— glandulosepalus

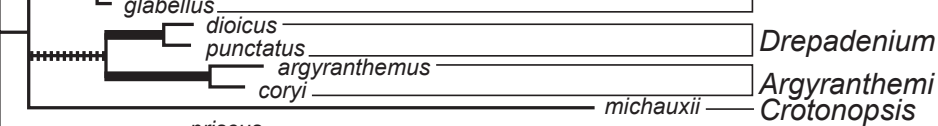

cory

[ jamaicensis

$-\left[\begin{array}{c}\text { grisebachianus } \\ \text { myricifolius }\end{array}\right.$

- nitens

- niveus

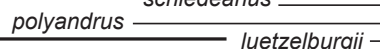

Luntia*

Cordiifolii

Pedicellati

Lamprocroton

Geiseleria*

Barhamia

Barhamia

Prisci

Eluteria*

Eutropia

Luetzelburgiorum

Cuneati

Cleodora*

Cyclostigma

Cupreati

Eremocarpus

Old World

L noronhae miarensis

- nobgyratus

zambesicus

- flavens

- linearis

- impressus

C. subg.

Adenophylli



humilis

humils

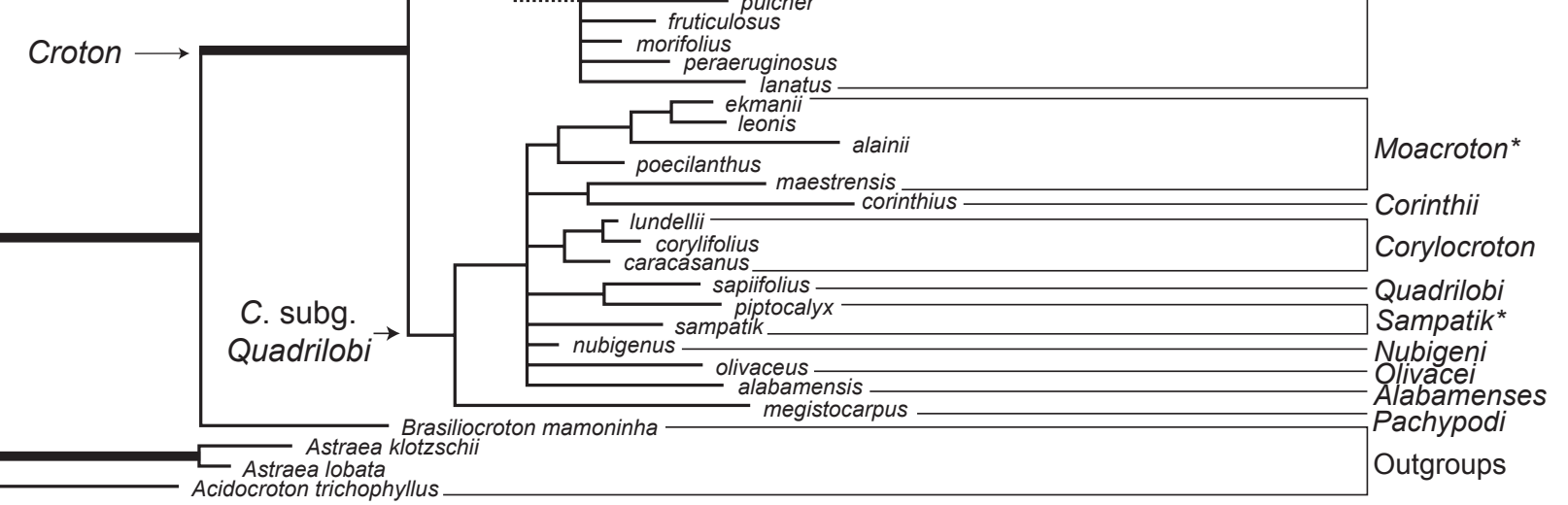

$=0.05$ substitutions per site 
Fig. 5. Bayesian phylogram of mitochondrial rps 3 data of Croton species and four outgroups. For explanation see Fig. 1 .



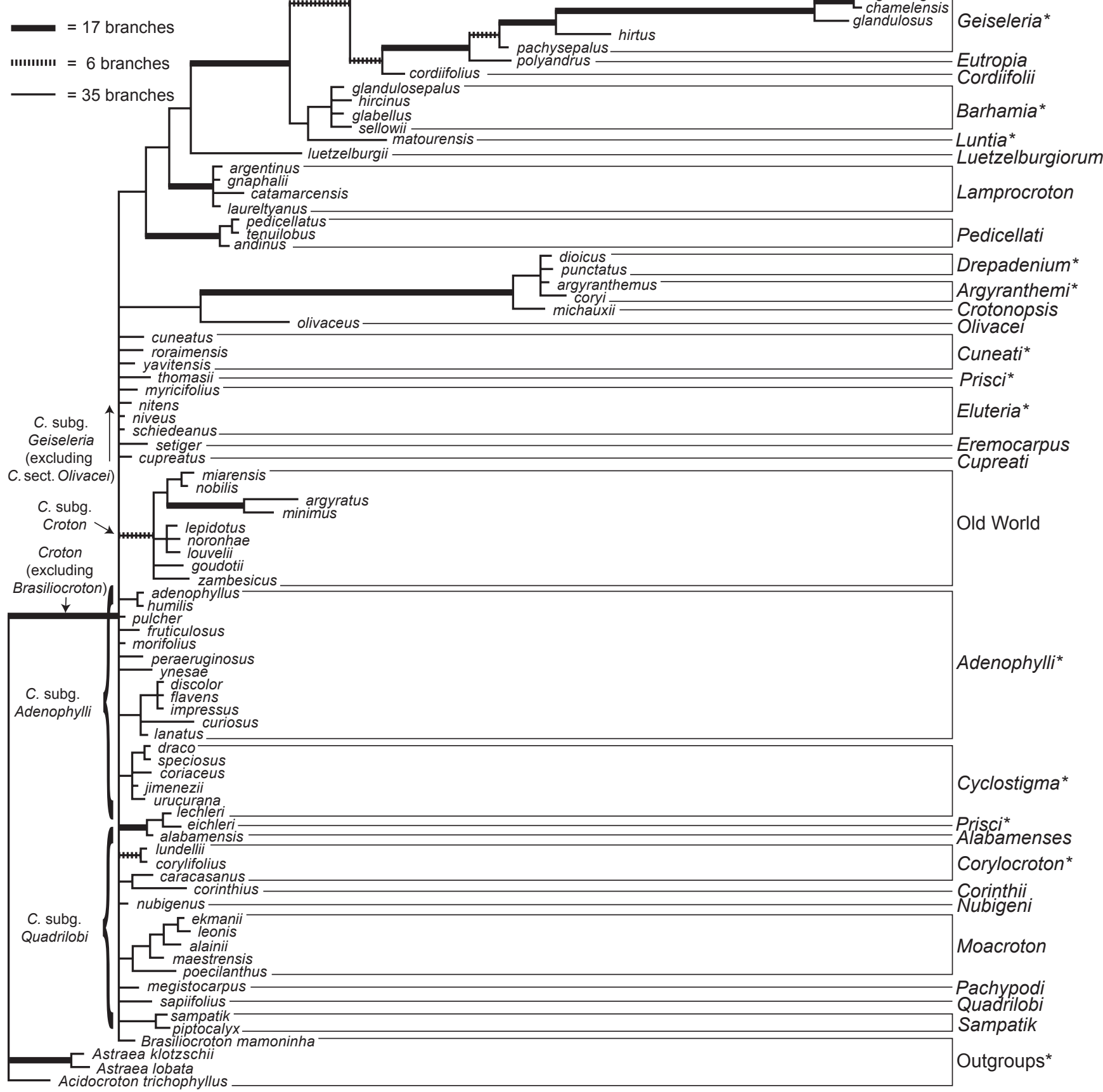

$-=0.05$ substitutions per site 


\section{Geographical and morphological patterns within New} World Croton. - Although Croton is most species-rich in South America, all three of its New World subgenera are widely distributed in the Americas. Narrowly endemic species are found in all groups, but nearly all species of $C$. subg. Quadrilobi are rare and restricted, whereas many species of $C$. subgenera Adenophylli and Geiseleria are common and widespread. Croton subg. Adenophylli consists of two of the largest sections, one of which, $C$. sect. Cyclostigma, consists primarily of trees, and the other, $C$. sect. Adenophylli, of shrubs. The inflated columella tip unique to $C$. sect. Adenophylli (Riina \& al., 2009) allows for easy identification of this section, which accounts for over a fifth of the species in the genus. Shrubs and trees characterize most sections and subgenera of Croton, but annual herbs are found only in Croton subg. Geiseleria.

Nearly all of the morphological characters that have been used to infer relationships within Croton, such as those used in the key, are homoplasious across the genus. Most of the larger sections are characterized by a suite of characters, which often overlap with other sections. Geography is often a good indicator of phylogenetic relatedness within the genus, with several morphologically convergent sections found in distinct areas, such as $C$. sect. Heptallon which is entirely North American, and the superficially similar $C$. sect. Pedicellati, which is mainly South American. Croton sect. Pedicellati is recovered sister to the sympatric $C$. sect. Lamprocroton (Fig. 1), and although there are morphological similarities between the two, it was not until molecular evidence was obtained that their close relationship was revealed.

Monophyletic formal groups. - Our hypotheses are that each of the formally named taxa that we recognize is monophyletic. However, due to a lack of resolution, or to "wild card" species such as C. trinitatis Millsp., or to species potentially of hybrid origin such as $C$. poecilanthus Urb., four of the sections that we recognize are recovered as non-monophyletic groups in the combined analysis (Fig. 1, indicated there with an asterisk).

Additional work is underway to address the relationships within Croton sect. Lasiogyne and its relationship to $C$. sects. Heptallon and Julocroton, and preliminary results (not shown) support the topology recovered in the ITS analysis (Fig. 2), which is the same as that found by Berry \& al. (2005) and Van Ee \& Berry (2010a), in which the three sections are each monophyletic groups within an unresolved trichotomy.

Croton sect. Geiseleria is rendered paraphyletic by C. trinitatis, which is recovered without support sister to $C$. sect. Barhamia in the combined analysis (Fig. 1). All of the remaining accessions of $C$. sect. Geiseleria otherwise make a highly supported clade. In the ITS phylogeny (Fig. 2) C. trinitatis is recovered within a monophyletic $C$. sect. Geiseleria, while in the EMB2765 exon 9 phylogeny (Fig. 3), it is sister to $C$. sect. Barhamia. Berry \& al. (2005) also recovered $C$. trinitatis within a well-supported $C$. sect. Geiseleria. Given that $C$. sect. Geiseleria is a morphologically cohesive group, and $C$. trinitatis is a very characteristic species within it, this may be a problem caused by an elevated rate of molecular substitution within C. trinitatis, and further investigation of its genome is warranted. Croton sect. Geiseleria is an otherwise well-supported natural group.
Croton sect. Eluteria, as circumscribed here in a broad sense, is not recovered as a monophyletic group; the combined (Fig. 1) and ITS (Fig. 2) analyses place C. myricifolius Griseb. (C. subsect. Cubenses) sister to $C$. subsect. Eluteria, while the trnL-F analysis (Fig. 4) places it sister to $C$. subsect. Jamaicenses. The EMB2765 exon 9 and rps 3 analyses (Figs. 3 and 5) recover the three subsections of $C$. sect. Eluteria unresolved with respect to each other. There is no support for $C$. sect. Eluteria not being monophyletic, and given the morphological and geographic evidence (Van Ee \& Berry, 2009a), we group these three groups as subsections of $C$. sect. Eluteria.

Croton sect. Moacroton is rendered paraphyletic by C. poecilanthus in the combined (Fig. 1) and ITS (Fig. 2) analyses. In the EMB2765 exon 9 (Fig. 3), trnL-F (Fig. 4), and rps3 (Fig. 5) phylogenies, $C$. poecilanthus is recovered in $C$. sect. Moacroton rather than with species of the "South American Grade" (sensu Van Ee \& al., 2008). The striking morphological resemblance between $C$. poecilanthus and species of $C$. sect. Moacroton, and the close relationship recovered in their $r b c L, n d h F$, and trnL-F analyses, led Van Ee \& al. (2008) to place it there, and to hypothesize that it may be of hybrid origin. The additional nuclear and mitochondrial gene trees presented here corroborate the placement of $C$. poecilanthus within $C$. sect. Moacroton.

Evolution of life history. - The mitochondrial rps 3 phylogeny (Fig. 5) shows a remarkable increase in the substitution rate in the branch leading to $C$. sects. Argyranthemi, Crotonopsis, and Drepadenium, and in the branches leading to $C$. sect. Pedicellati and others in the upper part of the figure. In contrast, the branch lengths in the analyses of the other loci are more even. A similar pattern of variable and elevated substitution rates in the mitochondrial genome has been reported for Silene L. (Caryophyllaceae; Städler \& Delph, 2002) and Plantago L. (Plantaginaceae; Cho \& al., 2004). Given their reputation for overall slower rates of evolution, mitochondrial genes have been identified as being suitable for resolving deep phylogenetic relationships (Knoop, 2004; Qiu \& al., 2006). In our analyses, the mitochondrial rps 3 gene provides resolution between Croton and two of the three outgroup genera, namely Astraea and Acidocroton, whereas the third outgroup, Brasiliocroton, is recovered within Croton (Fig. 5). It also provides supported resolution at higher levels within Croton, such as recovering $C$. sects. Argyranthemi, Crotonopsis, and Drepadenium as a highly supported clade, and $C$. sects. Heptallon, Julocroton, and Lasiogyne as another highly supported clade (Fig. 5). The sections with longer branches leading to them in the rps 3 phylogeny have in common that many of their members are annual herbs, compared to the tree and shrub habits of the sections with short branch lengths distributed along the polytomy towards the bottom of the phylogram (Fig. 5). Smith \& Donoghue (2008) evaluated rates of molecular evolution in angiosperms and demonstrated that a shift from the tree/ shrub habit to an herbaceous habit correlated with an increased rate of evolution. One possibility is that the groups in Croton that display elevated rates of rps3 evolution represent a shift from the perennial tree and shrub habit to an herbaceous habit, along with several reversals to the perennial habit. Such a reversal was demonstrated by Van Ee \& Berry (2010a) in $C$. sect. 
Heptallon, in which the perennial C. pottsii (Klotzsch) Müll. Arg. is embedded within a group of annual species.

Conclusions. - The work presented here, and the earlier papers that it builds on, bring us closer to a global understanding of the phylogenetic relationships and a comprehensive taxonomic classification of the complex and megadiverse genus Croton. Besides the need to assess the Old World species and their sectional delimitations, more phylogenetic and specieslevel taxonomic work needs to be done in the New World, such as the circumscription of $C$. sect. Lasiogyne and relationships and species circumscriptions within the large $C$. sects. Adenophylli and Geiseleria. Molecular data have been invaluable for resolving phylogenetic relationships within Croton and as an aid in identifying and circumscribing taxa. The insights they have provided and the careful examination of hundreds of type specimens and species protologues, together with the sectional key we developed, have enabled us to confidently assign to section 702 of the 712 species we recognize in the New World. In the Taxonomic Treatment below, we group the sections into four named subgenera, which facilitates discussion of larger assemblages of sections and avoids awkward references to informal clade names, such as "New World clade I", "New World clade II", and "Old World clade" that have been used in previous works. Although the subgenera are difficult to distinguish morphologically because they are each so diverse, and thus no key to them is provided, this is similar to the difficulties in trying to use nonmolecular characters to characterize many of the orders recognized by the Angiosperm Phylogeny Group (2009). We use the taxonomic categories of subgenus, section, and subsection to provide properly named and ranked groups, but we do not consider that all taxa of the same rank are necessarily equivalent.

\section{TAXONOMIC TREATMENT}

Croton subg. Croton, which is restricted to the Old World, is listed here to complete the four subgenera that we recognize within the genus. The number of species belonging to each section or subsection is given below and in parentheses at the start of the lists of included species. Species for which molecular sequence data are available in GenBank, published here or previously, appear in bold face in the individual section lists.

\section{Synopsis of the subgenera and the New World sections and subsections of Croton}

I. Croton subg. Croton (exclusively Old World)

II. Croton subg. Quadrilobi (Müll. Arg.) Pax in Engl. \& Prantl

1. C. sect. Olivacei Berry $-1 \mathrm{sp}$.

2. C. sect. Sampatik (G.L. Webster) Riina - 4 spp.

3. C. sect. Quadrilobi Müll. Arg. - $1 \mathrm{sp.}$

4. C. sect. Pachypodi B.W. van Ee - 5 spp.

5. C. sect. Moacroton (Croizat) B.W. van Ee $\&$ P.E. Berry $-8 \mathrm{spp}$.

6. C. sect. Nubigeni B.W. van Ee - 1 sp.

7. C. sect. Alabamenses B.W. van Ee - $1 \mathrm{sp}$.
8. C. sect. Corinthii B.W. van Ee - 1 sp.

9. C. sect. Corylocroton G.L. Webster - 11 spp.

III. Croton subg. Adenophylli (Griseb.) Riina,

B.W. van Ee \& P.E. Berry

10. C. sect. Cyclostigma Griseb. - 41 spp.

11. C. sect. Adenophylli Griseb. - 223 spp.

IV. Croton subg. Geiseleria A. Gray

12. C. sect. Cupreati Riina - 1 sp.

13. C. sect. Eremocarpus (Benth.) G.L. Webster $-1 \mathrm{sp}$.

14. C. sect. Cuneati (G.L. Webster) Riina \& P.E. Berry -11 spp.

15. C. sect. Eluteria Griseb. - 22 spp.

15a. C. subsect. Eluteria (Griseb.) B.W. van Ee $\&$ P.E. Berry - [15 spp.]

15b. C. subsect. Cubenses B.W. van Ee \& P.E. Berry - [4 spp.]

15c. C. subsect. Jamaicenses B.W. van Ee \& P.E. Berry - $[3$ spp. $]$

16. C. sect. Crotonopsis (Michx.) G.L. Webster $-1 \mathrm{sp}$.

17. C. sect. Argyranthemi B.W. van Ee - 2 spp.

18. C. sect. Drepadenium (Raf.) Müll. Arg. -6 spp.

19. C. sect. Prisci Riina - 3 spp.

20. C. sect. Pedicellati B.W. van Ee \& P.E. Berry - 20 spp.

21. C. sect. Lamprocroton (Müll. Arg.) Pax in Engl. \& Prantl $-37 \mathrm{spp}$.

21a. C. subsect. Lamprocroton (Müll. Arg.) B.W. van Ee \& P.E. Berry - [17 spp.]

21b. C. subsect. Argentini B.W. van Ee $\&$ P.E. Berry - [20 spp.]

22. C. sect. Luetzelburgiorum Riina - $1 \mathrm{sp}$.

23. C. sect. Cleodora (Klotzsch) Baill. - 18 spp.

24. C. sect. Cordiifolii Riina - $1 \mathrm{sp}$.

25. C. sect. Eutropia (Klotzsch) Baill. - $1 \mathrm{sp.}$

26. C. sect. Geiseleria (A. Gray) Baill. -82 spp.

27. C. sect. Barhamia (Klotzsch) Baill. - 84 spp.

27a. C. subsect. Barhamia (Klotzsch) B.W. van Ee - [19 spp.]

27b. C. subsect. Astraeopsis (Baill.) B.W. van Ee - $[4 \mathrm{spp}$. $]$

27c. C. subsect. Medea (Klotzsch) Pax in Engl. \& Prantl - [45 spp.]

27d. C. subsect. Micranthi (Baill.) B.W. van Ee - [13 spp. $]$

27e. C. subsect. Sellowiorum B.W. van Ee - [3 spp.]

28. C. sect. Luntia (Neck. ex Raf.) G.L. Webster - 19 spp.

29. C. sect. Julocroton (Mart.) G.L. Webster - 41 spp.

30. C. sect. Lasiogyne (Klotzsch) Baill. - 45 spp.

31. C. sect. Heptallon (Raf.) Müll. Arg. - 9 spp.

\section{Artificial key to the New World sections of Croton}

1. Herbs, subshrubs, or shrubs . . . . . . . . . . 2

1. Small to large trees (rarely lianas) . . . . . . . . 27

2. Leaves without glands at the base of the leaf blade or apex of the petiole ............... 3 
2. Leaves with glands at the base of the leaf blade or apex of the petiole ................... 19

3. Annual herbs; ovary 1-locular . . . . . . . . . . . . . 4

3. Annual to perennial herbs, subshrubs, or shrubs; ovary (2-) 3-locular . . . . . . . . . . . . . . . . 5

4. Low, mat-forming plants; leaves bristly stellate; inflorescences congested, hidden in the leaf axils or in dichotomies of stems; style 1, simple; fruit dehiscent; staminate flowers apetalous; western U.S.A. . . . 13. C. sect. Eremocarpus

4. Erect, loosely branching plants; leaves stellate-lepidote; inflorescences racemose; styles 3, simple to twice bifid; fruit indehiscent; staminate flowers with petals; eastern and central U.S.A.. . . . . . . . 16. C. sect. Crotonopsis

5. Sepals of pistillate flowers serrate, deeply divided, laciniate, or glandular-toothed. . . . . . . . . . . . . . 6

5. Sepals of pistillate flowers entire and eglandular . . . 9

6. Sepals of pistillate flowers deeply divided (laciniate), eglandular, strongly unequal in size . . 29. C. sect. Julocroton

6. Sepals of pistillate flowers divided $<1 / 2$ their length, usually glandular-toothed, and nearly equal in size . . . . 7

7. Stamens 10-45; columella persistent, with three prominent, smooth lobes angling outwards . . . . . . . . . . . . . . . . . . . . . . 11. C. sect. Adenophylli

7. Stamens 3-20; columella lacking prominent, smooth lobes. . . . . . . . . . . . . . . . 8

8. Stamens (3-)8-15(-20); numerous species, herbs to shrubs, widespread . . . . . . . . . . . 27. C. sect. Barhamia

8. Stamens 15; single low shrubby species from campos rupestres of Bahia, Brazil . . 22. C. sect. Luetzelburgiorum

9. Sepals of pistillate flowers reduplicate-valvate (the sepals are creased in the middle and flare outwards where they adjoin) . . . . . . . . . . . 30. C. sect. Lasiogyne

9. Sepals of pistillate flowers valvate (rarely imbricate), but not reduplicate . . . . . . . . . . . . . 10

10. Shrubs, usually $>1 \mathrm{~m}$ tall . . . . . . . . . . . . 11

10. Annual to perennial herbs or subshrubs, mostly $<1 \mathrm{~m}$ tall but occasionally robust individuals larger . . . . . . 15

11. Pistillate flowers sessile or subsessile, without petals; the columella persistent, with three prominent, smooth lobes angling outwards . . . . . . . 11. C. sect. Adenophylli

11. Pistillate flowers pedicellate, with or without petals; the columella lacking prominent, smooth lobes . . . . . . 12

12. Inflorescences terminal and/or axillary. . . . . . 13

12. Inflorescences terminal . . . . . . . . . . . . 14

13. Indumentum stellate to stellate-lepidote . . . . . . . . . . . . . . . . . . . . . 30. C. sect. Lasiogyne

13. Indumentum lepidote, or stellate on species only from Cuba and Jamaica . . . . . . . . . 15. C. sect. Eluteria

14. Styles multifid $(\geq 12$ terminal tips) . . . . . . . . . . . . . . . . . . . . . . . . 30. C. sect. Lasiogyne

14. Styles simple (3 terminal tips), or slightly flabellate at the tips. . . . . . . . . . . . 7. C. sect. Alabamenses

15. Dioecious or occasionally monoecious; staminate flowers without petals. . . . . . . . 18. C. sect. Drepadenium

15. Monoecious; staminate flowers with petals . . . . . 16

16. Staminate flowers with lepidote petals . . . . . . . . . 17. C. sect. Argyranthemi
16. Staminate flowers with glabrous or villous petals . . 17

17. Sepals of staminate and pistillate flowers with open aestivation; pistillate flowers pedicellate, pedicels often recurved . . . . . . . . . . . 20. C. sect. Pedicellati

17. Sepals of staminate and pistillate flowers valvate; pistillate flowers subsessile to pedicellate, pedicels straight to recurved . . . . . . . . . . . . . . . 18

18. Annual herbs or perennial subshrubs from a ligneous base, indumentum stellate; pistillate flowers pedicellate; North America . . . . . . . . . . . . 31. C. sect. Heptallon

18. Perennial shrubs, indumentum lepidote or stellate; pistillate flowers sessile to shortly pedicellate; South America . . . . . . . . . . . . . 21. C. sect. Lamprocroton

19. Stamens (2-)4-6, anthers subsessile, anthers not inflexed in bud (or else filamentous anthers 2 or 3 and inflexed in bud); Cuba. . . . . . . . . . . . . 5. C. sect. Moacroton

19. Stamens 5 to many, anthers filamentous, inflexed in bud; widespread .................... 20

20. Sepals of pistillate flowers markedly connate at base and then free, lobes imbricate or quincuncial; styles multifid and forming one or more fused stylar columns . . . . . .

23. $C$. sect. Cleodora

20. Sepals of pistillate flowers free or slightly connate at base, lobes valvate, reduplicate, open, or imbricate; styles bifid to multifid but not united into stylar columns . . . . . 21

21. Dioecious shrubs; stigmas bifid with 6 stigmatic tips; eastern Brazil (Bahia) . . . . . . . . . . . . . . . . . . 22

21. Monoecious or occasionally dioecious herbs or shrubs; stigmas bifid to multifid; widespread . . . . . . . 23

22. Flowers 5-merous; capsules muricate, 3-locular . . . . . . . . . . . . . . . . . . . 24. C. sect. Cordiifolii

22. Flowers 4-merous; capsules smooth, mostly 2-locular . . . . . . . . . . . . . . . 3. C. sect. Quadrilobi

23. Basalmost cymules of the inflorescence with both staminate and pistillate flowers. . . . . . . . . . . 24

23. Basalmost cymules of the inflorescence unisexual . 25

24. Indumentum stellate; sepals valvate or reduplicate-valvate; widespread in the Neotropics. . 10. C. sect. Cyclostigma

24. Indumentum lepidote to stellate-lepidote; sepals of pistillate flowers small and imbricate; a single species endemic to coastal restinga vegetation in Brazil (Bahia). . . . . . .

25. $C$. sect. Eutropia

25. Leaves usually dentate, generally with a pair of stipitate glands at the base and sometimes with glands in the leaf sinuses; sepals of pistillate flowers often free and unequal

26. $C$. sect. Geiseleria

25. Leaves usually entire or serrulate, with sessile or sometimes stipitate glands at the base, lacking glands in the leaf sinuses; sepals of pistillate flowers valvate and equal in size . . 26

26. Pistillate flowers sessile to subsessile, stigmas bifid to multifid, with 6 to numerous terminal tips; staminate flowers with short pedicels of similar length; widespread, with numerous species . . . . . . . 11. C. sect. Adenophylli

26. Pistillate flowers subsessile to shortly pedicellate, stigmas bifid, with 6 terminal tips; staminate flowers with pedicels of varying lengths; single species from montane Ecuador and Peru . . . . . . . . . . . 1. C. sect. Olivacei 
27. Leaves without glands at the base of the blade or apex of the petiole .................... 28

27. Leaves with glands at the base of the blade or apex of the petiole. . . . . . . . . . . . . . 30

28. Inflorescences terminal and axillary; pistillate flowers usually with well-developed petals . . 15. C. sect. Eluteria

28. Inflorescences terminal; pistillate flowers without petals . . . . . . . . . . . . . . . . . . . 29

29. Pistillate flowers sessile or subsessile, the sepals valvate but not reduplicate, the columella with three prominent, smooth lobes angling outwards . . . . . . 11. C. sect. Adenophylli

29. Pistillate flowers subsessile or pedicellate, the sepals reduplicate-valvate (the sepals are creased in the middle and flare outwards where they adjoin), the columella lacking prominent, smooth lobes . . . . . 30. C. sect. Lasiogyne

30. Stamens (2-)4-6 (if $>3$, then lacking filaments); styles simple or bifid, with 3 or 6 stigmatic tips; Cuba . . . . . . . . . . . . . . . . . . . . 5. C. sect. Moacroton

30. Stamens $>5$, filaments always present; styles bifid or multifid; widespread. . . . . . . . . . . . . . 31

31. Sepals of pistillate flowers noticeably reduplicate-valvate; styles multifid . . . . . . . . . . . . 32

31. Sepals of pistillate flowers valvate, imbricate, or basally connate, but not reduplicate; styles bifid or multifid . 34

32. Styles divided into 18-36 stigmatic tips; stamens 10-15; fruits smooth . . . . . . . . . . . . 28. C. sect. Luntia

32. Styles divided into 12-24 stigmatic tips; stamens 15-100 (-350); fruits smooth or muricate . . . . . . . . . 33

33. Leaves palmately veined (or lobed), the margins entire to dentate, eglandular; stamens $16-100(-350)$. . . . . . . .

. . . . . . . . . . . . 10. C. sect. Cyclostigma

33. Leaves pinnately veined, the margins crenate-dentate with sessile glands at the apices of the teeth; stamens 15-18

19. C. sect. Prisci

34. Sepals of pistillate flowers distinctly imbricate. . . . 35

34. Sepals of pistillate flowers valvate . . . . . . . 37

35. Inflorescences axillary and terminal; pistillate flowers subsessile, small, $<5 \mathrm{~mm}$ diam., sepals inconspicuous, stigmas bifid with 6 stigmatic tips; stamens 10-15; a single species endemic to coastal restinga vegetation in Brazil (Bahia) . . . . . . . . . . . . . 25. C. sect. Eutropia

35. Inflorescences terminal (rarely axillary); pistillate flowers subsessile to clearly pedicellate, $>5 \mathrm{~mm}$ diam., sepals generally persistent and conspicuous, stigmas multifid, with 12-30 stigmatic tips; stamens 15-25; multiple species from Mexico to South America . . . . . . . . . . . . 36

36. Adult leaves stellate or lepidote; leaf margins entire or dentate, without glands in the sinuses; sepals of pistillate flowers noticeably connate at the base, styles multifid with 12-30 terminal tips and basally connate, usually forming 1 or 3 stylar columns; stamens 15-25 . . 23. C. sect. Cleodora

36. Adult leaves nearly glabrous; leaf margins crenate-dentate, with glands in the sinuses; sepals of pistillate flowers barely connate at the base, styles quadrifid, with 12 terminal tips, not forming a stylar column; stamens 15-16 . . . . . . . . . . . 19. C. sect. Prisci (C. thomasii)

37. Pistillate flowers sessile or subsessile, the columella with three prominent, smooth lobes angling outwards; small trees (mostly shrubs) . . . . . . . 11. C. sect. Adenophylli

37. Pistillate flowers sessile to pedicellate, the columella lacking prominent smooth lobes; small to large trees. . . . 38

38. Leaf blades pinnately veined, margins dentate with stipitate glands along the margins, or on the lamina near the margins; styles distinct, bifid; capsules 3-lobed; seeds laterally compressed . . . . . . . . . 2. C. sect. Sampatik

38. Leaf blades pinnately or palmately veined or lobed, margins entire or dentate, but usually without marginal stipitate glands; styles distinct to partly connate, bifid or multifid; capsules terete to slightly lobed, seeds not laterally compressed . . . . . . . . . . . . . . . . 39

39. Indumentum on leaves lepidote or lepidote-stellate . . 40

39. Indumentum on leaves stellate or subglabrous . . . . 44

40. Leaf venation palmate-pinnate (3- or 5-nerved at base and pinnate above) ......................... 41

40. Leaf venation pinnate . . . . . . . . . . . . 42

41. Indumentum lepidote-stellate, never densely coppery-lepidote; stipules narrow and entire; various species, widespread. . . . . . . . . . . . 9. C. sect. Corylocroton

41. Indumentum densely coppery-lepidote; stipules foliose and dentate; one species, C. cupreatus, from montane Ecuador and Colombia . . . . . . . . . . . 12. C. sect. Cupreati

42. Leaf margins dentate, crenate, or loosely crenate to sinuous, usually with sessile or shortly stipitate discoid glands in the sinuses; seeds with the caruncle reduced, absent, or modified into an arillate structure . . . . 14. C. sect. Cuneati

42. Leaf margins entire, without glands; seeds carunculate $\mathbf{4 3}$

43. Inflorescences axillary and terminal, sometimes branched, terete; styles bifid, with 6 terminal tips; seeds large, $1-3 \mathrm{~cm}$ long; Costa Rica, Panama, and South America . . . . . . .

4. C. sect. Pachypodi

43. Inflorescences terminal, unbranched, and angular in crosssection; styles simple or flabellate, with 3 terminal tips; seeds $<1 \mathrm{~cm}$ long; cloud forests of Puerto Rico. . . . . . . . . . . . . . 5. C. sect. Moacroton (C. poecilanthus)

44. Leaf venation palmate or triplinerved, leaves sometimes 3lobed; styles bifid to multifid, with 6-30 terminal tips 45

44. Leaf venation pinnate or palmate-pinnate (3-nerved at base and parallel above); styles bifid, with 6 terminal tips (except $C$. sect. Corinthii, which is twice bifid with $12+$ terminal tips) . . . . . . . . . . . . . 46

45. Leaf blades entire to variously toothed or lobed, but without glands in the sinuses, also lacking domatia in the vein axils; stamens 16-100 (-350); seeds carunculate; numerous species, widespread. . . . . . 10. C. sect. Cyclostigma

45. Leaf blades crenate-dentate, with small glands in the sinuses, with dense, long tufts of trichomes (forming domatia) in the major leaf axils on the lower leaf surface and on both sides of the base; stamens 10-12; seeds without a caruncle; two species (C. aripoensis and $C$. domatifer) from cloud forests of Trinidad and northern Venezuela . . . . . . . . . . . . . . 14. C. sect. Cuneati

46. Leaf margins serrate to coarsely dentate, sometimes with glands in the sinuses; various species, widespread . . . . .9. C. sect. Corylocroton 
46. Leaf margins entire or subentire, if sinuous with glandular teeth and glands in the sinuses (C. sect. Quadrilobi) then the flowers 4-merous; all monotypic sections of narrow distributions. . . . . . . . . . . . . . . . 47

47. Dioecious; leaf margin sinuous with glands in the sinuses; stipules gland-tipped; flowers 4-merous; staminate inflorescences axillary, pistillate inflorescences terminal; one species in eastern Bahia, Brazil . . 3. C. sect. Quadrilobi

47. Monoecious; leaf margins entire or subentire, without glands; stipules eglandular; flowers 5-merous; inflorescences terminal . . . . . . . . . . . 48

48. Mature leaves sparsely to densely pubescent, lower surface with scattered glands in the axils of the secondary veins; styles twice bifid, with 12 or more terminal tips; one species in Atlantic coastal Costa Rica . . . . . .8. C. sect. Corinthii

48. Mature leaves sparsely pubescent to nearly glabrous, without glands on the lower surface; styles bifid, with 6 terminal tips; one species in Nicaragua and Honduras, another in South America . . . . . . . . . . . . . . . . . . . . . . 49

49. Petioles with pulvini at both ends (difficult to see when dried); stamens 13-15; one species in montane Nicaragua and Honduras. . . . . . . . . . . . . 6. C. sect. Nubigeni

49. Petioles without evident pulvini; stamens 30-40; one species in montane Ecuador and Peru . . 1. C. sect. Olivacei

Croton L., Sp. Pl.: 1004. 1753 E Oxydectes L. ex Kuntze, Revis. Gen. Pl. 2: 609. 1891, nom. illeg. \& superfl. Type: C. tiglium L., lectotype designated by Britton (1918: 207).

Although Webster (1993) superseded Small's (1913) choice of C. tiglium L. as the lectotype of Croton and designated C. aromaticus L., the valid lectotype of the genus is $C$. tiglium (Britton, 1918; Van Ee \& Berry, 2010b).

Trees, shrubs, or herbs, annual or perennial, monoecious or rarely dioecious; indumentum stellate to lepidote; latex usually present, clear to reddish. Leaves alternate or sometimes clustered or whorled below the inflorescences, simple, often with a lemony, pungent, or acrid odor when crushed, older leaves often turning orange before dehiscing; stipules present or absent; petiole present or absent; blade margins entire to toothed or lobed, glands present or absent at the base or along the margins and occasionally on the lamina; venation pinnate, or palmate at base and pinnate above. Inflorescences unisexual or bisexual with proximal pistillate flowers and distal staminate ones, terminal or axillary, spikes, heads, racemes, or thyrses. Staminate flowers: sepals (3-)5(-6), distinct or connate basally, valvate to imbricate; petals $(3-) 5(-6)$ or 0 , distinct, imbricate; disc extrastaminal, usually of 5 glands opposite the sepals; stamens (2-)4-100(-350), filaments inflexed in bud (nearly obsolete in $C$. sect. Moacroton), distinct, anthers basifixed, dehiscent longitudinally; pistillode absent. Pistillate flowers: sepals $(3-) 5(-10)$, distinct, imbricate, valvate, or reduplicatevalvate, distinct or connate basally; petals 5 or 0 (rudimentary), imbricate; disc annular or of 5 lobes opposite the sepals, or absent; pistils (1-, 2-) 3-carpellate, styles 1-3, simple, bifid, or multifid. Fruits capsules, rarely indehiscent. Seeds 1 per locule, seed coat dry, caruncle present, rarely absent or arillate.

\section{Croton subg. Croton - Type: C. tiglium L.}

Croton sect. Croton $\equiv$ Tiglium Klotzsch in Nov. Actorum Acad. Caes. Leop.-Carol. Nat. Cur. 19(Suppl. 1): 418. $1843 \equiv$ Croton sect. Tiglium (Klotzsch) Baill., Étude Euphorb.: 361. 1858 Eroton sect. Eucroton Baill., Étude Euphorb.: 354. 1858, nom. inval. - Type: C. tiglium L.

II. Croton subg. Quadrilobi (Müll. Arg.) Pax in Engler \& Prantl, Nat. Pflanzenfam. 3(5): 40. $1890 \equiv$ Croton sect. Quadrilobi Müll. Arg. in Linnaea 34: 78. 1865 - Type: C. sapiifolius Müll. Arg.

Croton subg. Moacroton was circumscribed by Van Ee \& al. (2008) to include species of $C$. sects. Alabamenses, Corinthii, Corylocroton, Moacroton, and Nubigeni, and they recovered species of $C$. sects. Olivacei, Pachypodi, and Sampatik as a grade at the base of this clade. The subgeneric classification of Croton adopted here places all of these into a single subgenus. However, the inclusion of $C$. sapiifolius, the type of the earlier name $C$. subg. Quadrilobi, which was not sampled by Van Ee $\&$ al. (2008), requires that this clade now be called $C$. subg. Quadrilobi instead of $C$. subg. Moacroton. This is somewhat of a misnomer for the group, since the only 4-merous species in the entire group is the type species, $C$. sapiifolius. This subgenus is characterized by its tree or large shrubby habit, and with the exception of $C$. corinthius, all species have simple or bifid styles with three or six stigmatic tips.

1. Croton sect. Olivacei P.E. Berry, sect. nov. - Arbores fruticesve parce stellata, foliis basi biglandulosis, stipulis integris; racemis terminalibus, pedicellis staminatis disparibus, staminibus 30 ad 40; sepalis pistillatis integris, valvatis; stylis bifidis. - Type: C. olivaceus Müll. Arg.

Description. - Monoecious shrubs or trees 2-7 m tall; indumentum sparsely stellate; latex present; leaves with 2 glands at the base; margins subentire; venation pinnate; stipules entire; inflorescences terminal, bisexual, lower cymules unisexual; stamens 30-40; sepals of pistillate flowers with open aestivation; petals of pistillate flowers absent; styles bifid for a total of 6 stigmatic tips.

Distribution and habitat. - This monotypic section is known from tropical premontane forests in Ecuador and Peru from 900 to $1600 \mathrm{~m}$.

Included species (1). - C. olivaceus Müll. Arg.

2. Croton sect. Sampatik (G.L. Webster) Riina, stat. nov. $\equiv$ Croton (sect. Cyclostigma Griseb.) subsect. Sampatik G.L. Webster in Taxon 42: 802. 1993 - Type: C. sampatik Müll. Arg.

Description. - Monoecious trees to $25 \mathrm{~m}$ tall; indumentum stellate or stellate-lepidote; leaves with 2 glands at base, glands sessile, on adaxial side of petiole; margins slightly sinuous to dentate, with an ovoid gland on each tooth and stipitate patelliform glands positioned at each sinus or near the margin on the abaxial side of the lamina; venation pinnate or palmate; stipules entire, linear; inflorescences terminal, bisexual, lower cymules unisexual; stamens 15-20; sepals of pistillate flowers 
with open to valvate aestivation; petals of pistillate flowers reduced; styles bifid for a total of 6 stigmatic tips; capsules 3-lobed; seeds compressed laterally.

Distribution and habitat. - Widespread in South America in the Amazon-Orinoco basins to the foothills of the Andes and in the Mata Atlântica forests of southeastern Brazil, from 100 to $900 \mathrm{~m}$.

Notes. - Croton sampatik, C. piptocalyx, and C. trombetensis were previously placed in C. sect. Cyclostigma (Webster, 1993; Secco \& al., 2001). An examination of their morphology and the molecular data supports this group as a separate lineage well removed from $C$. sect. Cyclostigma (Riina \& al., 2009). Webster (1993) listed six species in the description of $C$. subsect. Sampatik, and these have been shown to belong to five different sections, none of which are closely related.

Included species (4). - C. ater Croizat, C. piptocalyx Müll. Arg., C. sampatik Müll. Arg., C. trombetensis Secco, P.E. Berry \& N.A. Rosa.

3. Croton sect. Quadrilobi Müll. Arg. in Linnaea 34: 78. 1865

- Type: C. sapiifolius Müll. Arg.

Description. - Dioecious shrubs or trees 2-14 m tall; indumentum stellate to stellate-lepidote; leaves with 2 (4) glands at base, glands sessile, on adaxial side of petiole; margins entire to sinuous or dentate with glands in the sinuses and glandulartipped teeth; venation pinnate; stipules glandular-tipped; staminate inflorescences axillary; pistillate inflorescences terminal; flowers 4-merous; stamens 10-15; sepals of pistillate flowers valvate; petals of pistillate flowers absent; styles bifid for a total of 6 stigmatic tips; capsules obovate, 2-(3-)locular.

Distribution and habitat. - Endemic to low-elevation moist forests in southern Bahia, Brazil.

Notes. - At the time of the description of C. sect. Quadrilobi (Müller, 1865), C. sapiifolius was known only from the type collection. It was recently recollected, and Riina $\&$ al. (2010a) published additional details about the species' morphology, including evidence that it is probably dioecious, and that despite having three styles, nearly all the capsules are 2-locular. This section is unique in Croton in being 4-merous.

Included species (1). - C. sapiifolius Müll. Arg.

4. Croton sect. Pachypodi B.W. van Ee, sect. nov. - Arbores lepidota foliis basi inaequaliter biglandulosis, stipulis integris; racemis terminalibus axillaribusve; staminibus 14 ad 16; sepalis pistillatis integris, valvatis; stylis bifidis; capsulis 2-5 cm longis. - Type: C. pachypodus G.L. Webster. Description. - Monoecious trees to $30 \mathrm{~m}$ tall; indumentum lepidote; leaves with 2 glands at the base, the glands generally facing towards the abaxial side of the leaf; margins entire; venation pinnate; stipules entire; inflorescences terminal or terminal and axillary, bisexual or staminate, lower cymules unisexual, some cymules bisexual; stamens 14-16; sepals of pistillate flowers valvate; petals of pistillate flowers absent; styles bifid for a total of 6 stigmatic tips; mature capsules and seeds generally large, up to $5 \times 4 \mathrm{~cm}$ and $3 \times 2 \mathrm{~cm}$ respectively.

Distribution and habitat. - Croton sect. Pachypodi is a mainly South American group that reaches its northern limit in Costa Rica. It is found in humid montane and lower montane forests in Costa Rica, Panama, Colombia, Venezuela, Ecuador, Peru, Brazil, and Bolivia, from 50 to $1200 \mathrm{~m}$.

Notes. - This small section of at least five species possesses some of the largest fruits and seeds of all New World groups. Webster \& Huft (1988) incorrectly described C. pachypodus as having multifid styles; in this group, all species have bifid styles.

Included species (5). - C. diasii Pires ex Secco \& P.E. Berry, C. jorgei J. Murillo, C. maasii Riina \& P.E. Berry, C. megistocarpus J.A. González \& Poveda, C. pachypodus G.L. Webster.

5. Croton sect. Moacroton (Croizat) B.W. van Ee \& P.E. Berry in Bot. Rev. (Lancaster) 74: 158. $2008 \equiv$ Moacroton Croizat in J. Arnold Arbor. 26: 189. $1945 \equiv$ Croton subg. Moacroton (Croizat) B.W. van Ee \& P.E. Berry in Bot. Rev. (Lancaster) 74: 158. 2008 - Type: Moacroton leonis Croizat $\equiv$ C. leonis (Croizat) B.W. van Ee \& P.E. Berry.

$=$ Cubacroton Alain in Candollea 17: 116. $1960-$ Type: Cubacroton maestrensis Alain $\equiv$ Moacroton maestrensis (Alain) Radcl.-Sm. $\equiv$ Croton maestrensis (Alain) B.W. van Ee \& P.E. Berry.

$=$ Moacroton sect. Glaucifoliae Borhidi in Acta Bot. Acad. Sci. Hung. 36: 8. 1990 [1991] - Type: Moacroton trigonocarpus (Wright ex. Griseb.) Croizat $\equiv$ Croton trigonocarpus Wright ex. Griseb.

Description. - Monoecious shrubs or trees to $15 \mathrm{~m}$ tall; indumentum lepidote; leaves with 2 glands at base; margins entire or toothed; venation pinnate; coriaceous; stipules entire; inflorescences terminal, bisexual, lower cymules unisexual or bisexual; stamens (2-)4-6(-30); sepals of pistillate flowers with open aestivation; petals of pistillate flowers absent; styles simple, bifid, or flabellate for a total of 3 or 6 stigmatic tips.

Distribution and habitat. - Serpentine barrens in Cuba, and cloud forests in Cuba and Puerto Rico, from sea level to $1500 \mathrm{~m}$.

Notes. - Six species in this section are restricted to serpentine outcrops in Cuba, and sister to this serpentine radiation is C. maestrensis (Fig. 1), which is found in cloud forests on igneous substrates in the Sierra Maestra mountains of southeastern Cuba (Van Ee \& al., 2008). Croton maestrensis has staminate flowers with only two or three stamens and pistillate flowers with simple styles. Croton poecilanthus, endemic to the rainforests of the Luquillo mountains of eastern Puerto Rico, is placed in this section given its remarkable morphological similarity to the Cuban species, with the exception of it having up to 30 stamens compared to a maximum of six in any of the other members. This relationship is supported by the phylogenetic signal of the chloroplast genome (Fig. 4; Van Ee \& al., 2008), and at least in part by the nuclear EMB2765 exon 9 and the mitochondrial rps3 gene trees (Figs. 3 and 5).

Included species (8). - C. alainii B.W. van Ee \& P.E. Berry, C. cristalensis Urb., C. ekmanii Urb., C. leonis (Croizat) B.W. van Ee \& P.E. Berry, C. maestrensis (Alain) B.W. van Ee \& P.E. Berry, C. poecilanthus Urb., C. revolutus (Alain) B.W. van Ee \& P.E. Berry, C. trigonocarpus Wright ex. Griseb. 
6. Croton sect. Nubigeni B.W. van Ee, sect. nov. - Arbores parce stellata foliis basi biglandulosis, stipulis integris; pulvinibus ad basin et apicem petiolo; racemis terminalibus; staminibus 13 ad 15; sepalis pistillatis integris; stylis bifidis. - Type: C. nubigenus G.L. Webster.

Description. - Monoecious trees to $7 \mathrm{~m}$ tall; indumentum stellate but mostly nearly glabrous; leaves with 2 glands at the base; margins subentire; venation pinnate; petioles with pulvini at both ends; stipules entire; inflorescences terminal, bisexual or unisexual, lower cymules unisexual; stamens 13-15; sepals of pistillate flowers with open aestivation; petals of pistillate flowers absent; styles bifid for a total of 6 stigmatic tips.

Distribution and habitat. - This monotypic section is endemic to humid forests from 200 to $1200 \mathrm{~m}$ in Honduras and Nicaragua.

Notes. - Webster (1988) suggested that Croton nubigenus was closely related to the Jamaican C. lucidus L. (as C. wilsonii Griseb.) and the Mexican C. ynesae Croizat, and ultimately referred them to the mainly Old World $C$. sect. Croton (as $C$. sect. Tiglium (Klotzsch) Baill.). Croton lucidus and C. ynesae are members of $C$. sect. Adenophylli (Fig. 1), and their main similarity with $C$. nubigenus is that they are nearly totally glabrous. Webster (1988) also suggested that C. nubigenus might be closely related to the Brazilian C. sapiifolius (C. sect. Quadrilobi) or the Old World C. verreauxii Baill., but ultimately its relationship lies with geographically closer species, rather than with those that appear similar morphologically. Webster (1988) described $C$. nubigenus as dioecious, but additional field work has revealed that it is monoecious, although most inflorescences and collections are unisexual.

Included species (1). - C. nubigenus G.L. Webster.

7. Croton sect. Alabamenses B.W. van Ee, sect. nov. - Frutices lepidoti foliis eglandulosis, estipulatis; racemis terminalibus; staminibus 10 ad 15; sepalis pistillatis integris, valvatis, petalis viridis evolutis; stylis simplicibus. - Type: C. alabamensis E.A. Sm. ex Chapm.

Description. - Monoecious shrubs to $3 \mathrm{~m}$ tall; indumentum lepidote; leaves without visible glands when fully developed, but vestigial glands distinguishable at the base of developing leaf blades on the adaxial side; stipules absent; inflorescences terminal, bisexual or staminate, lower cymules unisexual; stamens 10-15; sepals of pistillate flowers valvate; petals of pistillate flowers well developed; styles simple to flabellate at the tips for a total of 3 stigmatic tips, although these may sometimes appear slightly divided at the tips.
Distribution and habitat. - This monotypic section is endemic to the southern United States, with $C$. alabamensis var. alabamensis found in Bibb and Tuscaloosa counties in Alabama, and C. alabamensis var. texensis Ginzbarg in Coryell, Bell, and Travis counties in Texas (Ginzbarg, 1992; Van Ee \& al., 2006; Wurdack, 2006). It occurs above the coastal plain on limestone, dolomite, and shale outcroppings and adjacent outwashes, from 50 to $300 \mathrm{~m}$.

Notes. - This is one of the few groups that have simple styles (Fig. 6B).

Included species (1). - C. alabamensis E.A. Sm. ex Chapm., with two varieties: $C$. alabamensis var. alabamensis and $C$. alabamensis var. texensis Ginzbarg.

8. Croton sect. Corinthii B.W. van Ee, sect. nov. - Arbores stellata foliis basi biglandulosis, glandulis in axillis venarum secundariis abaxialis; stipulis integris; pulvinibus ad basin et apicem petioloracemis terminalibus; racemis terminalibus; staminibus 15 ad 17; sepalis pistillatis integris, valvatis; stylis bisbifidis vel plus. - Type: $C$. corinthius Poveda \& J.A. González.

Description. - Monoecious trees to $10 \mathrm{~m}$ tall; indumentum stellate; leaves with 2 glands at the base and scattered glands in the axils of the secondary veins on the abaxial side; margins subentire; venation pinnate; petioles with pulvini at both ends; stipules entire; inflorescences terminal, bisexual, lower cymules unisexual; stamens 15-17; sepals of pistillate flowers valvate; petals of pistillate flowers absent; styles twice bifid or more for a total of 12 or more stigmatic tips per flower.

Distribution and habitat. - This monotypic section is endemic to humid forests between 50 and $250 \mathrm{~m}$ of Limón, Costa Rica, near the Atlantic coast. It has been located at one more locality in addition to the two published in González Ramírez \& Poveda Álvarez (2003; J. González Ramírez, pers. comm.).

Notes. - The scattered glands in the axils of the secondary veins on the abaxial leaf surface of $C$. corinthius is a distinctive characteristic that also appears in Leandri's "Groupe Adenophorum" (Leandri, 1939) from Madagascar, and similar glands are found in C. sect. Luntia (Riina \& al., 2010b). The presence of pulvini at both ends of the petioles appears to be a synapomorphy shared with the closely related $C$. sect. Nubigeni. These pulvini shrink when dry and are not readily visible on herbarium specimens.

Included species (1). - C. corinthius Poveda \& J.A. González.

Fig. 6. Diagnostic floral and vegetative features of Croton used in the sectional key. A, Unilocular ovary and simple style of Croton setiger (C. sect. Eremocarpus). Trichomes are stellate with a long, porrect central ray (ex cult., MICH). B, Pistillate flowers of Croton alabamensis (C. sect. Alabamenses), showing simple styles from a trilocular ovary, petals, and discrete disk glands (ex cult., MICH). C, Pistillate flowers of Croton arboreus (C. sect. Eluteria subsect. Eluteria), showing multifid styles, petals, and muricate ovaries (Van Ee 472, WIS). D, stalked acropetiolar glands of Croton sipaliwinensis (C. sect. Geiseleria) (Prance 4293, NY). E, recurved, stipitate petiolar glands of Croton cupreatus (C. sect. Cupreati) (Riina 1408, WIS). F, multiple acropetiolar and epipetiolar sessile to stipitate glands of Croton lechleri (C. sect. Cyclostigma) from central Ecuador (Riina \& López 1393, WIS). G, bisexual cymules along the inflorescence axis of Croton lechleri (C. sect. Cyclostigma) from eastern Peru, showing open pistillate flowers with bifid styles and no petals, and staminate flowers still in bud (Riina \& Ruiz 1490, WIS). $\mathbf{H}$, pistillate flowers of Croton sphaerogynus (C. sect. Cleodora), showing quincuncial sepal aestivation and basal stylar column (Sant'Ana \& al. 1122, CEPEC). I, bisexual inflorescence cymules of Croton eichleri (C. sect. Prisci), showing smaller staminate flowers in bud and larger pistillate flowers opening, with reduplicate-valvate sepals (Riina \& Caruzo 1525, SP). All photos by the authors. 


9. Croton sect. Corylocroton G.L. Webster in Taxon 42: 806 . 1993 - Type: C. corylifolius Lam.

Description. - Monoecious shrubs or trees to $15 \mathrm{~m}$ tall; indumentum stellate to stellate-lepidote; leaves with 2 glands at base, glands usually stipitate, on adaxial side of petiole; margins serrate to coarsely dentate, with or without glands in the sinuses; venation pinnate, 3 -veined at the base; stipules entire; inflorescences terminal; bisexual or staminate, lower cymules bisexual or pistillate; stamens 10-18; sepals of pistillate flowers valvate; petals of pistillate flowers reduced or absent; styles bifid for a total of 6 stigmatic tips.

Distribution and habitat. - Deciduous forests of the Antilles, southern Mexico, and South America, and evergreen cloud forests of Central America, from sea level to $1600 \mathrm{~m}$.

Notes. - In the description of this section Webster (1993) included only four species. Several members were previously placed in C. sects. Adenophylli and Cyclostigma (Webster, 1993; Martínez Gordillo, 1996), but the phylogenetic results of Van Ee \& al. (2008) and Riina \& al. (2009) confirm their placement here. Webster (2001) assigned the closely related C. mcvaughii G.L. Webster and C. repens Schltdl. to C. sect. Corylocroton, based in part on their coarsely dentate leaves, but they have since been shown to belong in $C$. sect. Geiseleria (Van Ee, 2006). The species of this section require a taxonomic revision, given that some names, such as $C$. lundellii Standl. and C. beetlei Croizat, may represent more than one taxon.

Included species (11). - C. beetlei Croizat, $\boldsymbol{C}$. caracasanus Pittier, C. corylifolius Lam., C. grewiifolius Müll. Arg., C. lundellii Standl., C. mexicanus Müll. Arg., C. oerstedianus Müll. Arg., C. pagiveteris Croizat, $\boldsymbol{C}$. quercetorum Croizat, C. tonduzii Pax, C. verapazensis Donn. Sm.

III. Croton subg. Adenophylli (Griseb.) Riina, B.W. van Ee \& P.E. Berry, stat. nov. $\equiv$ Croton sect. Adenophylli Griseb., Fl. Brit. W.I.: 40. 1859 ('Adenophyllus') - Type: C. adenophyllus Bertero ex Spreng.

This subgenus contains two of the largest sections of the genus. Croton sect. Cyclostigma consists of large shrubs to large trees, nearly all of which have copious latex. Species of $C$. sect. Adenophylli rarely get larger than shrub-size. Both of these sections are otherwise very diverse, and numerous species belonging to them have been erroneously placed elsewhere, and vice versa. We rely here on the more extensive molecular sampling in the revisions of Van Ee (2006) and Riina \& al. (2009) to help place species in these two sections.

10. Croton sect. Cyclostigma Griseb., Fl. Brit. W.I.: 42.1859 $\equiv$ Croton subsect. Cyclostigma (Griseb.) Müll. Arg. in Linnaea 34: 81. $1865 \equiv$ Croton ser. Cyclostigma (Griseb.) Müll. Arg. in Martius, Fl. Bras. 11(2): 91.1873 - Type: C. gossypiifolius Vahl.

$=$ Cyclostigma Klotzsch in Seemann, Bot. Voy. Herald: 104. 1853, nom. illeg. non Cyclostigma Hochst. ex Endl. (1842) - Type: Cyclostigma panamense Klotzsch, lectotype designated by Wheeler in Taxon 24: 535. 1975 三 Croton panamensis (Klotzsch) Müll. Arg. = C. draco Schltdl. \& Cham.
Description. - Monoecious trees or large shrubs; indumentum stellate; yellow, orange, or more usually red latex present; leaves with 2 or more glands at base, glands sessile or stipitate, on abaxial or adaxial side of petiole; lamina entire or lobed, margins entire, serrate, or dentate; venation palmate or triplinerved; stipules conspicuous, entire or dissected, filiform, foliose, auriculate, or subulate; inflorescences terminal, bisexual, lower cymules bisexual or rarely just staminate; stamens 16-100(-350); sepals of pistillate flowers valvate, reduplicatevalvate, rarely imbricate; petals of pistillate flowers reduced to a glandular filament or absent; styles bifid to multifid for a total of 6-24+ stigmatic tips per flower.

Distribution and habitat. - Secondary vegetation, roadsides, river banks, and landslide areas of dry to wet forests from central Mexico and Central America to tropical and subtropical South America, from sea level to $3000 \mathrm{~m}$.

Notes. - We concur with Webster (1993) that Grisebach's (1859: 37-42) C. sect. Cyclostigma is not based on Klotzsch's (1853) illegitimate genus Cyclostigma, and therefore is not typified by it. Therefore, C. gossypiifolius Vahl, which was the only species mentioned by Grisebach (1859: $37-42)$, is the obligate type of the section. There is great morphological diversity within $C$. sect. Cyclostigma in the stipules, petiolar glands (Fig. 6F), stamen number, and style branching (Figs. $6 \mathrm{G}$ and $7 \mathrm{~A}-\mathrm{B})$. In a recent survey of the wood anatomy of C. sect. Cyclostigma and other sections, Wiedenhoeft \& al. (2009) found secondary xylem rays containing laticifers only in species of $C$. sect. Cyclostigma. These laticifer-containing rays can be regarded as the only known morphological synapomorphy for the section. Laticifers in the pith and bark are common in several sections of Croton.

Riina \& al. (2009) identified C. sect. Cyclostigma as a source of incongruence, with ITS placing it sister to $C$. sect. Adenophylli, and trnL-F placing it embedded within $C$. subg. Geiseleria sister to C. cupreatus Croizat (C. sect. Cupreati), which is also where our analysis of trnL-F places it (Fig. 4). The analysis of EMB2765 exon 9 recovers $C$. sects. Adenophylli and Cyclostigma as a strongly supported clade (Fig. 3), while the analysis of rps 3 does not resolve the position of C. sect. Cyclostigma, but neither does it place it with C. cupreatus (Fig. 5). It is not surprising to find cases of incongruence between gene trees such as this in a large group such as Croton, in which there have probably been multiple events of reticulation and incomplete lineage sorting. Possible cases of hybridization events deep in the phylogeny have been identified and discussed in previous studies (Van Ee \& al., 2008; Riina \& al., 2009).

Included species (41). - C. alchorneicarpus Croizat, C. anisodontus Müll. Arg., C. aristophlebius Croizat, C. boavitanus Croizat, C. caldensis Müll. Arg., C. celtidifolius Baill., C. charaguensis Standl., C. churutensis Riina \& X. Cornejo, C. coriaceus Kunth, C. draco Schltdl. \& Cham., C. echinocarpus Baill., C. erythrochilus Müll. Arg., C. erythrochyloides Croizat, C. fastuosus Müll. Arg., C. floccosus B.A. Sm., C. gossypiifolius Vahl, C. hibiscifolius Kunth ex Spreng., C. huberi Steyerm., C. jimenezii Standl. \& Valerio, C. lagoensis Müll. Arg., C. lechleri Müll. Arg., C. macrobothrys Baill., 
C. medusae Müll. Arg., C. mutisianus Kunth, C. perspeciosus Croizat, C. pilulifer Rusby, C. plagiograptus Müll. Arg., C. pseudopopulus Baill., C. purdiei Müll. Arg., C. quadrisetosus Lam., C. redolens Pittier, C. rimbachii Croizat, $\boldsymbol{C}$. rusbyi Britton ex Rusby, C. sibundoyensis Croizat, C. speciosus Müll. Arg., C. turumiquirensis Steyerm., C. tyndaridum Croizat, C. urucurana Baill., C. vulnerarius Baill. Placed here with some uncertainty: C. buchii Urb., C. lindmanii Urb.

11. Croton sect. Adenophylli Griseb., Fl. Brit. W.I.: 40. 1859 ('Adenophyllus') - Type: C. adenophyllus Bertero ex Spreng.

= Semilta Raf., Sylva Tellur.: 63. 1838 - Type: S. althaeifolia (Mill.) Raf. $=$ C. flavens $\mathrm{L}$.

$=$ Croton sect. Velamea Baill. in Adansonia 4: 316. 1864 - Type: C. campestris A. St.-Hil., lectotype designated by Webster in Taxon 42: 808. 1993.

$=$ Croton subsect. Xalapenses G.L. Webster in Contr. Univ. Michigan Herb. 23: 356. 2001 - Type: C. xalapensis Kunth.

Description. - Monoecious (rarely dioecious) shrubs or subshrubs, rarely small trees; indumentum stellate, rarely lepidote; leaves with or without glands at the base; margins entire, serrate, or dentate, occasionally glandular; venation palmate, triplinerved, or pinnate; stipules lobed, dissected, glandular, or entire; inflorescences terminal, bisexual, lower cymules unisexual; stamens 10-45; sepals of pistillate flowers valvate, sometimes glandular; petals of pistillate flowers reduced or absent; columella tipped with three smooth, ascending, inflated apical lobes; styles bifid or twice bifid for a total of 6 or 12 stigmatic tips.

Distribution and habitat. - In a wide variety of habitats, many of them semiarid and often in secondary vegetation, in the southern United States, Mexico, Central America, the West Indies, and all countries of South America, from sea level to $3000 \mathrm{~m}$.

Notes. - As defined here, Croton sect. Adenophylli is the largest and most ubiquitous New World section of Croton. It includes $C$. sect. Velamea Baill., C. (sect. Cyclostigma) subsect. Xalapenses G.L. Webster, and Webster's (1993) concept of $C$. sect. Cascarilla Griseb. The recognition of Croton cascarilla (L.) L. as a synonym of C. eluteria (L.) W. Wright (Van Ee \& Berry, 2010b), requires a change of name relative to that used by Webster (1993). The species of $C$. sect. Adenophylli, as circumscribed more narrowly by Webster (1993), have twice bifid styles and glandular leaves, stipules, and sepals, and are embedded as a monophyletic subclade of $C$. sect. Adenophylli. The inflated distal columella lobes identified as a synapomorphy for the section by Riina \& al. (2009), combined with their typically sessile to subsessile pistillate flowers and unisexual cymules, serve to identify members of this section.

Croton sect. Adenophylli is by far the largest of the New World sections and will require considerable work to resolve synonymies among the many published names. The list below is our current best estimate of accepted species, although we expect to find some of them to be conspecific, and also some additional new species to be found and described.
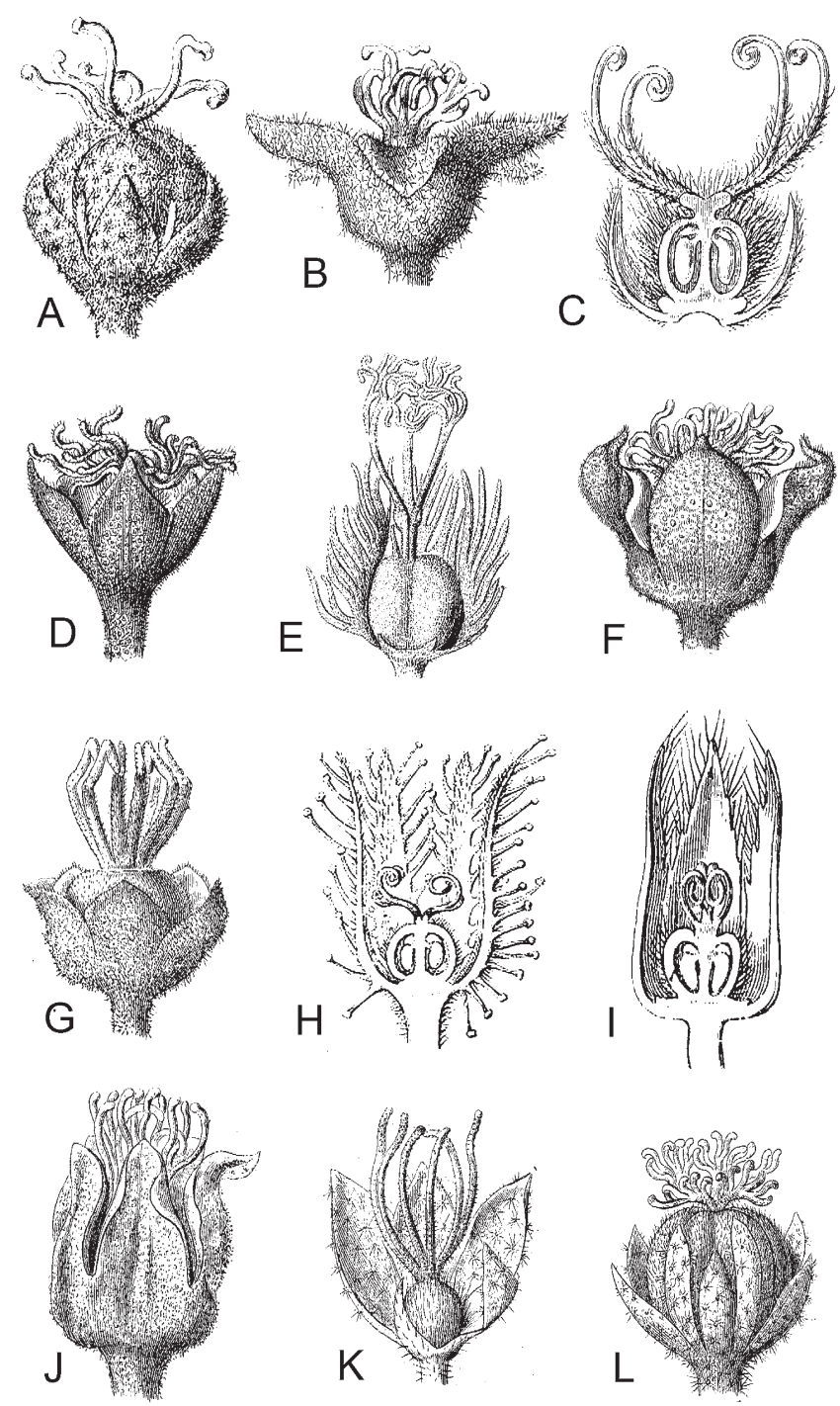

Fig. 7. Pistillate flower diversity of Croton in the New World. A, Croton urucurana ( $C$. sect. Cyclostigma) with valvate sepals, reduced filamentous petals, bifid styles, and stellate trichomes; B, Croton caldensis $(C$. sect. Cyclostigma) with valvate sepals that are joined at the base, multifid styles, and stellate trichomes; C, Croton grandivelus (treated as C. pohlianus Müll. Arg. in Müller, 1873) (C. sect. Adenophylli) with valvate sepals and bifid styles; D, Croton palanostigma (C. sect. Luntia) with valvate sepals, multifid styles, and lepidote trichomes; E, Croton stipularis (C. sect. Julocroton) with laciniate and unequal sepals, the two inner sepals (facing towards the axis of the inflorescence) are much reduced compared to the three outer sepals, and multifid styles; F, Croton floribundus (C. sect. Lasiogyne) with reduplicate-valvate sepals, multifid styles, and lepidote trichomes; G, Croton sphaerogynus (C. sect. Cleodora) with quincuncial sepals that are joined less than half their length; $\mathbf{H}$, Croton chaetocalyx (C. sect. Barhamia subsect. Barhamia) with valvate, glandular sepals; I, Croton timandroides (C. sect. Barhamia subsect. Medea) with laciniate sepals and multifid styles; J, Croton sellowii (C. sect. Barhamia subsect. Sellowiorum) with reduplicate-valvate sepals and multifid styles; K, Croton bidentatus (C. sect. Geiseleria) with unequal sepals, bifid styles, and stellate trichomes; L, Croton sincorensis (C. sect. Geiseleria) with unequal sepals, multifid styles, and stellate trichomes. Illustrations reproduced from Flora Brasiliensis (Müller, 1873), not to scale. 
Included species (223). - C. abeggii Urb. \& Ekman, C. abutilifolius Croizat, $\boldsymbol{C}$. abutiloides Kunth, C. acunae Borhidi, C. adenophyllus Bertero ex Spreng., C. adipatus Kunth, C. adspersus Benth., C. aequatoris Croizat, C. agrarius Baill., C. agrophilus Müll. Arg., C. albellus Müll. Arg., C. alloeophyllus Urb., C. alnifolius Lam., C. alnoideus Baill., C. amphileucus Briq., C. angustifolius Ham., C. apicifolius Croizat, C. araripensis Croizat, C. artibonitensis Urb., C. azuensis Urb., C. balsameus Müll. Arg., C. balsensis V.W. Steinmann \& M.J. Martínez Gordillo, C. bangii Rusby, C. barahonensis Urb., C. barbatus Kunth, C. betaceus Baill., C. boliviensis Müll. Arg., C. bonplandianus Baill., C. borhidii O.Muñiz, C. brachytrichus Urb., C. bryophorus Croizat, C. caboensis Croizat, C. campestris A. St.-Hil., C. cardenasii Standl., C. catharinensis L.B. Sm. \& Downs, C. chamanus Steyerm., C. chilensis Müll. Arg., C. chimboracensis P.E. Berry \& Riina, C. chrysocladus Müll. Arg., C. churumayensis Croizat, $C$. ciliatoglandulifer Ortega, C. cinerascens Radcl.Sm. \& Govaerts, C. clavuliger Müll. Arg., C. comayaguanus Standl. \& L.O. Williams, C. conduplicatus Kunth, C. corallicola Borhidi, C. cordobensis Ahumada, C. cortesianus Kunth, C. corumbensis S. Moore, C. craspedotrichus Griseb., C. curiosus Croizat, C. curuguatyensis Ahumada, C. curvipes Urb., C. cycloideus Borhidi \& O. Muñiz, C. discolor Willd., C. disjunctus V.W. Steinmann, C. doctoris S. Moore, C. echioideus Baill., C. eggersii Pax, C. ehrenbergii Schltdl., C. emporiorum Croizat, C. excisus Urb., C. ferruginellus Müll. Arg., C. ferrugineus Kunth, $\boldsymbol{C}$. flavens L., C. flavescens Greenm., C. flaviglandulosus Lundell, C. fragilis Kunth, C. francoanus Müll. Arg., C. fraseri Müll. Arg., C. frieseanus Müll. Arg., C. fruticulosus Torr., C. fulvus Mart., C. glyptospermus Müll. Arg., C. gracilipes Baill., C. grandivelum Baill., C. guilleminianum Baill., C. heliotropiifolius Kunth, C. heterochrous Müll. Arg., C. heteroneurus Müll. Arg., C. hieronymi Griseb., C. hilarii Baill., C. holguinensis Borhidi, C. holtonii Müll. Arg., C. horridulus (Baill.) Müll. Arg., C. huajuapanensis M.J. Martínez Gordillo \& Cruz Durán, C. humilis L., C. hypoleucus Schltdl., C. impressus Urb., C. incanus Kunth, C. incertus Müll. Arg., C. intercedens Müll. Arg., C. jacmelianus Urb., C. jamesonii Müll. Arg., C. japirensis Müll. Arg., C. jucundus Brandegee, C. kalkmannii Müll. Arg., C. kleinii L.B. Sm. \& Downs, C. laceratoglandulosus Caruzo \& Cordeiro, C. lachnocladus Mart. ex Müll. Arg., C. lachnostachyus Baill., C. laeticapsulus Croizat, C. lanatus Lam., C. lapanus Müll. Arg., C. lasiopetaloides Croizat, C. lehmannii Pax, C. leptostachyus Kunth, C. leucophlebius C. Wright ex Griseb., C. limnocharis Croizat, C. linearis Jacq., C. longifolius Müll. Arg., C. lucidus L., C. magdalenae Millsp., C. mazapensis Lundell, C. medians Müll. Arg., C. megaladenus Urb., C. menthodorus Benth., C. meridensis Croizat, C. michaelii V.W. Steinmann, C. micradenus Urb., C. miradorensis Müll. Arg., C. miraflorensis Borhidi, C. missionum Croizat, C. mollis Benth., C. monogynus Urb., C. morifolius Willd., C. munizii Borhidi, C. nephrophyllus Urb. \& Ekman, C. nitidulifolius Croizat, C. nudulus Croizat, C. olanchanus Standl. \& L.O. Williams, C. ophiticola Borhidi, C. orbignyanus Müll. Arg., C. orientesensis Borhidi,
C. origanifolius Lam., C. pachyrachis Alain, C. pallidus Müll. Arg., C. panduriformis Müll. Arg., C. paraensis Müll. Arg., C. patrum L.B. Sm. \& Downs, C. pavonis Müll. Arg., C. payaquensis Standl., C. pedersenii Ahumada, C. pellitus Kunth, C. peltophorus Müll. Arg., C. peraeruginosus Croizat, C. peraffinis Müll. Arg., C. perlongiflorus Croizat, C. persicaria Baill., C. peruvianus Briq., C. pervestitus C. Wright ex Griseb., C. petraeus Müll. Arg., C. piauhiensis Müll. Arg., C. poitaei Urb., C. polygonoides L.B. Sm. \& Downs, C. polytomus Urb., C. priorianus Urb., C. prostratus Urb., C. pulcher Müll. Arg., C. pungens Jacq., C. pycnanthus Benth., C. rehderianus Croizat, C. reitzii L.B. Sm. \& Downs, C. rhamnifolioides Pax \& K. Hoffm., C. rivinifolius Kunth, C. rosarianus M.J. Martínez Gordillo \& Cruz Durán, $C$. roxanae Croizat, C. ruizianus Müll. Arg., C. sagraeanus Müll. Arg., C. saltensis Griseb., C. sanctae-crucis S. Moore, C. sancti-lazari Croizat, C. sapiiflorus Croizat, C. scouleri Hook.f., C. seminudus Müll. Arg., C. semivestitus Müll. Arg., C. shreveanus Croizat, C. soliman Cham. \& Schltdl., C. sonorae Torr., C. soratensis Müll. Arg., C. sphaerocarpus Kunth, C. spurcus Croizat, C. stenopetalus G.L. Webster, C. stenophyllus Griseb., C. stenosepalus Müll. Arg., C. stenotrichus Müll. Arg., C. stipulaceus Kunth, $C$. suaveolens Torr., C. suavis Kunth, C. subacutus (Baill.) Müll. Arg., C. subcomosus Müll. Arg., C. subdecumbens Borhidi \& O. Muñiz, C. suberosus Kunth, C. subferrugineus Müll. Arg., C. subfragilis Müll. Arg., C. subjucundus Croizat, C. subsuavis Croizat, C. subvillosus Müll. Arg., C. suyapensis Ant. Molina, C. tarapotensis Müll. Arg., C. tejucensis Müll. Arg., C. tenuifolius Pax \& K. Hoffm., C. thurifer Kunth, C. timotensis Pittier, C. tremulifolius Croizat, C. turnerifolius S. Moore, C. vaccinioides A. Rich., C. vaillantii Geiseler, C. vauthierianus Baill., C. velame Müll. Arg., C. vepretorum Müll. Arg., C. versicolor Müll. Arg., C. viminalis Griseb., C. virletianus Müll. Arg., C. vitifolius Lundell, C. wagneri Müll. Arg., C. websteri M.J. Martínez Gordillo \& J. Jiménez Ram., C. xalapensis Kunth, C. xanthochylus Croizat, C. yecorensis V.W. Steinmann \& Felger, C. ynesae Croizat, C. ypanemensis Müll. Arg., C. yungensis Croizat.

IV. Croton subg. Geiseleria A. Gray, Manual, ed. 2: 391. 1856 - Type: C. glandulosus L.

Croton subg. Geiseleria is the only subgenus in which annual species are found. Although the annual habit is clearly derived within Croton, Van Ee \& Berry (2010a) documented a reversal from annual to perennial in $C$. sect. Heptallon.

12. Croton sect. Cupreati Riina, sect. nov. - Arbores lepidota foliis basi biglandulosis, glandulis stipitatis, recurvatis; stipulis foliaceis dentatis; racemis terminalibus; staminibus 10 ad 12; sepalis pistillatis integris, valvatis; stylis bifidis. - Type: C. cupreatus Croizat.

Description. - Monoecious trees to $20 \mathrm{~m}$ tall; indumentum minutely lepidote; leaves with 2 elongate, recurved glands at the base; margins entire to serrate, sometimes with sessile ovoid glands in the sinuses towards the base of the leaf; venation palmate or pinnate; stipules foliaceous, dentate; inflorescences 
terminal, bisexual; lower cymules bisexual; stamens 10-12; sepals of pistillate flowers valvate; petals of pistillate flowers absent; styles bifid for a total of 6 stigmatic tips.

Distribution and habitat. - Andean cloud forests of northern Ecuador and southeastern Colombia, from 1800 to $2200 \mathrm{~m}$.

Notes. - This monotypic section has unusual stipitate petiolar glands that arise from an expanded rounded base on the adaxial side of the petiole, and then curve down towards the abaxial side ending in a clavate head (Fig. 6E).

Included species (1). - C. cupreatus Croizat.

13. Croton sect. Eremocarpus (Benth.) G.L. Webster in Novon 2: 270.1992 E Eremocarpus Benth., Bot. Voy. Sulphur: 53. $1844 \equiv$ Piscaria Piper in Contr. U.S. Natl. Herb. 11: 382. 1906, nom. illeg. \& superfl. $\equiv$ Croton subg. Eremocarpus (Benth.) Radcl.-Sm. \& Govaerts in Kew Bull. 52: 184. 1997 - Type: Eremocarpus setigerus (Hook.) Benth. $\equiv C$. setiger Hook.

Description. - Monoecious annual prostrate herbs; indumentum bristly-stellate; leaves without glands at the base; margins entire; venation palmate; stipules absent; inflorescences pseudoterminal at dichotomies of the stems, bisexual, lower cymules unisexual (but inflorescences very congested); staminate flowers apetalous, stamens 5-10; sepals of pistillate flowers absent; petals of pistillate flowers absent; ovary 1-locular, style simple with 1 stigmatic tip.

Distribution and habitat. - Roadsides, fencerows, vineyards, and disturbed areas in western Mexico and U.S.A, naturalized elsewhere, as in Chile, South Africa, and Australia, from 50 to $1800 \mathrm{~m}$.

Notes. - This monotypic section stands apart both morphologically and molecularly, with no close relatives identified by either method. The reduction of the pistillate flower to a single carpel (Fig. 6A) has occurred independently in $C$. sect. Crotonopsis and in at least one Old World species (C. miarensis Leandri). Berry \& al. (2005) identified Croton setiger and $C$. insularis Baill., an Old World species, as sources of incongruence between ITS and $\operatorname{trnL}-F$, although this was primarily restricted to their maximum parsimony analyses. In the combined analyses (Fig. 1), we recover $C$. setiger in the same position as Berry \& al. (2005) did in their combined Bayesian analysis, and none of the separate analyses place it anywhere else with any support.

Included species (1). - C. setiger Hook.

14. Croton sect. Cuneati (G.L. Webster) Riina \& P.E. Berry in Taxon 59: 1153. 2010 E Croton (sect. Luntia (Neck. ex Raf.) G.L. Webster) subsect. Cuneati G.L. Webster in Taxon 42: 804. 1993 - Type: C. cuneatus Klotzsch.

Description. - Monoecious trees to $20 \mathrm{~m}$ tall; indumentum lepidote, stellate-lepidote, and stellate; leaves with 2 glands at the base; margins loosely crenate or sinuous, crenate or dentate, usually with sessile or shortly stipitate discoid glands in the sinuses, and sometimes less obvious ovoid glands on the teeth; venation pinnate; stipules entire; inflorescences terminal, often clustered, unisexual or bisexual; lower cymules unisexual or bisexual; stamens 10-20; sepals of pistillate flowers valvate; petals of pistillate flowers absent; styles bifid or twice bifid for a total of 6-12 stigmatic tips; seeds with a reduced or absent caruncle, or with the caruncle modified into an arillate structure.

Distribution and habitat. - This entirely South American section, including the adjacent Caribbean island of Trinidad, consists of rainforest trees found from seasonally flooded riparian Amazonian lowland forests on the slopes of tepuis in the Guayana Shield and the Venezuelan Coastal Range, from 100 to $2500 \mathrm{~m}$.

Notes. - Croton sect. Cuneati is most diverse in northern South America, with one species, C. cuneatus, being widespread throughout the Amazon and Orinoco river basins of South America. The section includes C. aripoensis Philcox and $C$. domatifer Riina \& P.E. Berry, the only known species of Croton with domatia on the leaves. Croton sect. Cuneati is distinctive in having some lowland riverine species that have seeds with caruncles modified into arils, which was hypothesized by Riina \& al. (2010b) as an adaptation for dispersal by fish. Riina $\&$ al. (2010b) provide a phylogeny and detailed synonymy for the section.

Included species (11). - C. aripoensis Philcox, C. cuneatus Klotzsch, C. domatifer Riina \& P.E. Berry, C. icabarui Jabl., C. malambo H. Karst., C. neblinae Jabl., C. roraimensis Croizat, C. tessmannii Mansf., C. yavitensis Croizat. Placed here with some uncertainty: $C$. polypleurus Croizat, $C$. subasperrimus Secco, P.E. Berry \& Rosário.

15. Croton sect. Eluteria Griseb., Fl. Brit. W.I.: 39. $1859 \equiv$ Croton subg. Eluteria (Griseb.) Pax in Engler \& Prantl, Nat. Pflanzenfam. 3(5): 38. 1890 - Type: Croton eluteria (L.) W. Wright $\equiv$ Clutia eluteria $\mathrm{L}$.

= Cascarilla Adans., Fam. Pl. 2: 355. $1763 \equiv$ Croton sect. Cascarilla (Adans.) Griseb., F1. Brit. W.I.: 38: 1859 - Type: Croton cascarilla (L.) L. $\equiv$ Clutia cascarilla L. = Croton eluteria (L.) W. Wright.

Description. - Monoecious trees and shrubs; indumentum lepidote to stellate; leaves without glands at the base; margins entire to serrate; venation pinnate or palmate; stipules rudimentary or absent; inflorescences axillary and terminal, bisexual, lower cymules unisexual; stamens 10-16; sepals of pistillate flowers valvate; petals of pistillate flowers well-developed to reduced; styles multifid for a total of more than 12 stigmatic tips.

Notes. - Several species of Croton sect. Eluteria have been described recently (Martínez Gordillo \& Cruz Durán, 2002; Webster, 2005; León Enríquez \& Vester, 2006; León Enríquez \& Martínez Gordillo, 2008; Van Ee \& Berry, 2009a), but the biggest change since Webster (1993) is the return to Grisebach's (1859: 37-42) concept of the group suggested by the molecular results of Van Ee \& Berry (2009a). Here we describe the three clades of $C$. sect. Eluteria as subsections, and although they appear superficially to be quite distinct, they share axillary inflorescences, lepidote trichomes, a lack of glands on the leaves, and multifid styles (Fig. 6C). All species of $C$. subsect. Eluteria are lepidote, and one of the three species in each of the other two subsections is lepidote while the others are stellate. Both $C$. subsects. Cubenses and Jamaicenses have members that are multiple-stemmed shrubs. 


\section{Key to the subsections of Croton sect. Eluteria}

1. Petals of pistillate flowers well developed; stipular spines absent; indumentum lepidote; widespread . . . . . . . . . . . . . . . . . . . . . . . 15a. C. subsect. Eluteria

1. Petals of pistillate flowers reduced or absent; stipular spines present or absent; indumentum lepidote or stellate; Cuba and Jamaica . . . . . . . . . . . . . . . . . 2

2. Spines present or absent, if spines absent then leaves $<1 \mathrm{~cm}$ long; Cuba . . . . . . . . . 15b. C. subsect. Cubenses

2. Spines absent, leaves $>5 \mathrm{~cm}$ long; Jamaica . . . . . . . . . . . . . . . . . 15c. C. subsect. Jamaicenses

15a. Croton subsect. Eluteria (Griseb.) B.W. van Ee \& P.E. Berry, stat. nov. $\equiv$ Croton sect. Eluteria Griseb., Fl. Brit. W.I.: 39. 1859 - Type: C. eluteria (L.) W. Wright.

Description. - Single-stemmed trees and shrubs; petals of pistillate flowers present, well developed; spines absent; leaf margins entire; indumentum lepidote. (Fig. 6C).

Distribution and habitat. - Widely distributed in the West Indies, and from Mexico to tropical South America. Dry, open vegetation to rainforests, from sea level to $1700 \mathrm{~m}$.

Included species (15). - C. arboreus Millsp., C. carpostellatus B.L. León \& M.J. Martínez Gordillo, C. eluteria (L.) W. Wright, C. fantzianus F. Seym., C. gomezii G.L. Webster, $C$. guatemalensis Lotsy, $C$. icche Lundell, $C$. mayanus B.L. León \& H.F.M. Vester, C. nitens Sw., C. niveus Jacq., C. pseudoniveus Lundell, C. reflexifolius Kunth, C. schiedeanus Schltdl., C. sousae M.J. Martínez Gordillo \& Cruz Durán, C. tenuicaudatus Lundell.

15b. Croton subsect. Cubenses B.W. van Ee \& P.E. Berry, subsect. nov. - Frutices spinosi vel non spinosi, lepidoti vel stellati, foliis marginibus integris vel serratis; petalis pistillatis nullis vel deminutis. - Type: C. bispinosus C. Wright. Description. - Single or multiple-stemmed shrubs; petals of pistillate flowers reduced or absent; spines present or absent; leaf margins entire or serrate; indumentum lepidote to stellate.

Distribution and habitat. - Endemic to Cuba. Dry, scrubby vegetation from sea level to $500 \mathrm{~m}$.

Notes. - Given its small, lepidote leaves, C. myricifolius was placed by Webster (1993) in C. sect. Lamprocroton, but using molecular data Van Ee \& Berry (2009a) placed it in a highly supported clade with two spinose Cuban species with which it shares axillary inflorescences.

Included species (4). - C. bispinosus C. Wright, C. brittonianus Carabia, C. jaucoensis Borhidi, C. myricifolius Griseb.

15c. Croton subsect. Jamaicenses B.W. van Ee \& P.E. Berry, subsect. nov. - Frutices lepidoti vel stellatis, non spinosi, foliis marginibus integris vel serratis; petalis pistillatis nullis vel deminutis. - Type: C. jamaicensis B.W. van Ee \& P.E. Berry.

Description. - Multiple-stemmed shrubs and small singlestemmed trees; petals of pistillate flowers reduced or absent; spines absent; leaf margins entire or serrate; indumentum lepidote to stellate.
Distribution and habitat. - Endemic to Jamaica. Dry, scrubby vegetation on limestone and moister upland areas, from sea level to $700 \mathrm{~m}$.

Notes. - Croton laurinus is a small tree, while C. grisebachianus and C. jamaicensis are multiple-stemmed shrubs from drier and lower elevations of the southern part of Jamaica. Croton laurinus was placed by Grisebach (1859: 37-42) in C. sect. Eluteria, and its exclusion from the section by Müller (1865) had been followed until molecular data confirmed its relationship with the more traditional, lepidote-leaved species of $C$. subsect. Eluteria (Van Ee \& Berry, 2009a).

Included species (3). - C. grisebachianus Müll. Arg., C. jamaicensis B.W. van Ee \& P.E. Berry, C. laurinus Sw.

16. Croton sect. Crotonopsis (Michx.) G.L. Webster in Novon 2: 270. $1992 \equiv$ Crotonopsis Michx., Fl. Bor.-Amer. 2: 185. $1803 \equiv$ Leptemon Raf. in Med. Repos. 5: 353. 1808, nom. superfl. \& illeg. $\equiv$ Friesia Spreng., Anleit. Kenntn. Gew. 2(2): 885. 1818, nom. superfl. \& illeg. $\equiv$ Croton subg. Crotonopsis (Michx.) Radcl.-Sm. \& Govaerts in Kew Bull. 52: 183. 1997 - Type: Crotonopsis linearis Michx. $\equiv$ Croton michauxii G.L. Webster.

Description. - Monoecious annual erect herbs; indumentum appressed-stellate to stellate-lepidote; leaves without glands at the base; margins entire; venation pinnate; stipules lacking; inflorescences terminal and axillary, bisexual, lower cymules unisexual; stamens 5-6; sepals of pistillate flowers with open aestivation; petals of pistillate flowers reduced; ovary 1-locular; styles 3; styles simple to twice bifid for a total of 3-12 stigmatic tips; fruit indehiscent.

Distribution and habitat. - Endemic to the United States along the east and Gulf coasts, and inland along the Mississippi River. Sandy soils, forest openings, and rocky outcrops, from sea level to $300 \mathrm{~m}$.

Notes. - Many workers have recognized two species in Croton sect. Crotonopsis, but Pursh (1814) and Van Ee \& Berry (2009b) joined them as varieties of a single species. The unilocular ovaries of Croton sect. Crotonopsis have what appear to be three multifid styles, and its fruits are indehiscent.

Included species (1). - C. michauxii G.L. Webster, with two varieties: $C$. michauxii var. michauxii and $C$. michauxii var. elliptica (Willd.) B.W. van Ee \& P.E. Berry.

17. Croton sect. Argyranthemi B.W. van Ee, sect. nov. - Herbae annuae vel perennes interdum robusta, stellata vel lepidota, foliis eglandulosis, integris; racemis terminalibus; staminibus 10 ad 16, petalis staminatis valde lepidotis; stylis bis- vel terbifidis. - Type: C. argyranthemus Michx.

Description. - Monoecious erect herbs or subshrubs, annual or perennial; indumentum lepidote or stellate and lepidote; leaves without glands at the base; margins entire; stipules entire or lacking; inflorescences terminal, bisexual, lower cymules unisexual; stamens 10-16; petals of staminate flowers densely covered with lepidote scales on the abaxial side; sepals of pistillate flowers equal or unequal, valvate; petals of pistillate flowers absent; styles twice or three times bifid for a total of 12-24 stigmatic tips. 
Distribution and habitat. - Sandy soils of the coastal plains of the southern United States and northeastern Mexico, from sea level to $100 \mathrm{~m}$.

Notes. - This section of two known species is endemic to North America. Croton argyranthemus was previously placed in the Old World C. sect. Argyrocroton (Müll. Arg.) G.L. Webster by Webster $(1967,1993)$, and Croizat (1942) hypothesized that $C$. coryi was related to members of $C$. sect. Heptallon. These two species, although appearing overall very different (C. argyranthemus has lepidote foliage, and $C$. coryi has stellate foliage), share the synapomorphy of having a dense covering of lepidote scales on the abaxial side of the petals of their staminate flowers. Croizat

Included species (2). - C. argyranthemus Michx., C. coryi

18. Croton sect. Drepadenium (Raf.) Müll. Arg. in Linnaea 34: 79. 1865 三 Drepadenium Raf., Neogenyton: $2.1825 \equiv$ Croton subg. Drepadenium (Raf.) Pax in Engler \& Prantl, Nat. Pflanzenfam. 3(5): 40. 1890 - Type: Drepadenium maritimum (Walter) Raf. $\equiv$ C. maritimus Walter $=C$. punctatus Jacq.

$=$ Hendecandra Eschsch. in Mém. Acad. Imp. Sci. St. Pétersbourg, Hist. Acad. 10: 287. 1826 - Type: Hendecandra procumbens Eschsch. $\equiv$ C. californicus Müll. Arg.

= Penteca Raf., Sylva Tellur.: 62. 1838 - Type: Penteca tomentosa Raf. $=C$. dioicus Cav.

= Astrogyne Benth., Pl. Hartw.: 14. 1839 - Type: Astrogyne crotonoides Benth. $=C$. dioicus Cav.

= Banalia Raf., Autik. Bot.: 50. 1840 - Type: B. muricata Raf.

$=$ C. texensis (Klotzsch) Müll. Arg.

Description. - Monoecious or dioecious shrubs, subshrubs, and herbs; indumentum appressed-stellate to stellate-lepidote; leaves without glands at the base; margins entire; venation pinnate to slightly 3 -veined at the base; stipules reduced or lacking; inflorescences terminal, unisexual or rarely bisexual, lower cymules unisexual; stamens 8-12; petals of staminate flowers absent; sepals of pistillate flowers valvate; petals of pistillate flowers absent; styles multifid for a total of 24 or more stigmatic tips; columella stout, winged, readily breaking off from the receptacle.

Distribution and habitat. - Croton sect. Drepadenium is a primarily North American group which would be endemic to Mexico and the United States except for the widespread, sand dune species $C$. punctatus, which extends along the Atlantic coast to northern South America. Deserts, prairies, sand dunes, limestone and igneous mountains, open, disturbed vegetation, from sea level to $2000 \mathrm{~m}$.

Notes. - The lack of petals in the staminate flowers is a synapomorphy for $C$. sect. Drepadenium. Species of $C$. sect. Drepadenium are dioecious, with the exception of $C$. punctatus, although most collections of this species are unisexual.

Included species (6). - C. californicus Müll. Arg., C. dioicus Cav., C. parksii Croizat, C. punctatus Jacq., C. texensis (Klotzsch) Müll. Arg., C. wigginsii L.C. Wheeler.
19. Croton sect. Prisci Riina, sect. nov. - Arbores fruticesve stellati, foliis basi biglandulosis, marginibus glandulosodentatis; racemis terminalibus, cymulis inferioribus bisexualibus; staminibus 15 ad 18; sepalis pistillatis reduplicatis vel imbricatis; stylis bisbifidis. - Type: C. priscus Croizat. Description. - Monoecious trees 2-7 $\mathrm{m}$ tall; indumentum stellate-appressed or stellate-rosulate; leaves with 2-4 glands at the base; margins crenate-dentate, with sessile glands at the apex of the teeth; venation pinnate; stipules linear, entire or divided; inflorescences terminal, bisexual, lower cymules bisexual; stamens 15-18; sepals of pistillate flowers reduplicate, reduplicate-valvate, or slightly imbricate; petals of pistillate flowers absent; styles quadrifid for a total of 12 stigmatic tips.

Distribution and habitat. - Occurring in moist forests of the Brazilian states of São Paulo, Rio de Janeiro, and Bahia, from 100 to $800 \mathrm{~m}$.

Notes. - Croton priscus was placed by Webster (1993) in C. sect. Cyclostigma, however molecular and morphological evidence indicate that this species forms a separate monophyletic group with C. eichleri and C. thomasii (Riina \& al., 2009; 2010a).

Included species (3). - C. eichleri Müll. Arg., C. priscus Croizat, $\boldsymbol{C}$. thomasii Riina \& P.E. Berry.

20. Croton sect. Pedicellati B.W. van Ee \& P.E. Berry in Syst. Bot. 36: 93. 2011 - Type: C. pedicellatus Kunth.

Description. - Monoecious subshrubs 0.5-1.0 m tall; indumentum stellate to stellate-lepidote; leaves without glands at the base; margins entire; venation pinnate to slightly 3-veined at the base; stipules entire, inconspicuous; inflorescences terminal, bisexual or staminate, lower cymules unisexual; stamens 6-12; pedicels of pistillate flowers often recurved; sepals of pistillate flowers with open aestivation; petals of pistillate flowers absent; styles bifid for a total of 6 stigmatic tips, columella with a prominent tip.

Distribution and habitat. - Croton sect. Pedicellati is distributed disjunctly between Mexico and South America, with its greatest diversity in eastern Brazil. It is found in scrubby tropical deciduous forests in Mexico and Brazil, as well as in dry inter-Andean valleys in Colombia, Peru, and Bolivia, from 200 to $2500 \mathrm{~m}$.

Notes. - A preliminary list of species included in $C$. sect. Pedicellati was prepared by Van Ee \& Berry (2011), although many of these are very similar and several may prove to be synonymous. The molecular phylogeny of Van Ee \& Berry (2011) indicates that molecular data may be able to resolve species boundaries.

Included species (20). - C. acradenius Pax \& K. Hoffm., C. andinus Müll. Arg., C. angustifrons Müll. Arg., C. breedlovei B.W. van Ee \& P.E. Berry, C. burchellii Müll. Arg., C. catinganus Müll. Arg., C. cerinodentatus Müll. Arg., C. corchoropsis Baill., C. cuyabensis Pilg., C. dracunculoides Baill., C. eriocladoides Müll. Arg., C. eriocladus Müll. Arg., C. horminum Baill., C. linearifolius Müll. Arg., C. longicolumellus B.W. van Ee \& P.E. Berry, C. pachecensis S. Moore, C. pedicellatus Kunth, C. tenuicaulis B.W. van Ee \& P.E. Berry, C. tenuilobus S. Watson, C. tridentatus Mart. ex Müll. Arg. 
21. Croton sect. Lamprocroton (Müll. Arg.) Pax in Engler \& Prantl, Nat. Pflanzenfam. 3(5): 40. $1890 \equiv$ Croton ser. Lamprocroton Müll. Arg. in Martius, Fl. Bras. 11(2): 244. 1873 - Type: C. ceanothifolius Baill., lectotype designated by Webster in Taxon 42: 815. 1993.

Description. - Monoecious or dioecious shrubs or subshrubs $0.2-3.0 \mathrm{~m}$ tall; indumentum stellate, stellate-lepidote, or lepidote; leaves without glands at the base; margins entire; venation pinnate; stipules entire, inconspicuous or absent; inflorescences terminal, bisexual or unisexual, lower cymules unisexual; stamens 9-16; sepals of pistillate flowers equal or unequal, imbricate, valvate, or reduplicate-valvate; petals of pistillate flowers reduced or absent; styles bifid or twice bifid for a total of 6-12 stigmatic tips.

Notes. - Müller (1873) included species with both bifid and twice bifid styles in this group, while Webster (1993) recircumscribed the section to include only those with bifid styles. Lima \& Pirani (2008) returned to Müller's (1873) circumscription of the group by including species with both bifid and multifid styles. This broader concept of the section was supported by the molecular phylogenetic analysis of Van Ee \& Berry (2011), in which the bifid-styled species were recovered as a clade sister to the multifid-styled species. This led them to recognize each clade as a subsection of $C$. sect. Lamprocroton.

\section{Key to the subsections of Croton sect. Lamprocroton}

1. Styles bifid, stigmatic tips $6 \ldots \ldots \ldots \ldots \ldots$ . . . . . . . . . . . . 21a. C. subsect. Lamprocroton

1. Styles twice or more bifid, stigmatic tips 12 or more . . . . . . . . . . . . . . . 21b. C. subsect. Argentini

21a. Croton subsect. Lamprocroton (Müll. Arg.) B.W. van Ee \& P.E. Berry in Syst. Bot. 36: 93. $2011 \equiv$ Croton ser. Lamprocroton Müll. Arg. in Martius, Fl. Bras. 11(2): 244. 1873 - Type: C. ceanothifolius Baill.

Description. - Indumentum primarily lepidote; styles bifid, stigmatic tips 6 .

Distribution and habitat. - This South American group is most diverse in Brazil, but extends into adjacent Paraguay, Argentina, Uruguay, and Bolivia. It is found most commonly in open vegetation on sandy or rocky ground, including rock outcrops, from 100 to $2800 \mathrm{~m}$, but some members are also known from riparian and swampy habitats (Lima \& Pirani, 2008).

Included species (17). - C. ceanothifolius Baill., C. chloroleucus Müll. Arg., C. dichrous Müll. Arg., C. dusenii Croizat, C. ericoides Baill., C. erythroxyloides Baill., C. imbricatus L.R. Lima \& Pirani, C. muellerianus L.R. Lima, C. myrianthus Müll. Arg., C. pallidulus Baill., C. perintricatus Croizat, C. pseudoadipatus Croizat, C. pygmaeus L.R. Lima, C. splendidus Mart. ex Colla, C. subcinerellus Croizat, C. tenellus Müll. Arg., C. uruguayensis Baill.

21b. Croton subsect. Argentini B.W. van Ee \& P.E. Berry in Syst. Bot. 36: 93. 2011 - Type: C. argentinus Müll. Arg.

Description. - Indumentum primarily stellate; styles twice or more bifid, stigmatic tips 12 or more.
Distribution and habitat. - Croton subsect. Argentini is also entirely South American, but its center of diversity appears to be south of Brazil in Uruguay and Argentina.

Included species (20). - C. argentinus Müll. Arg., C. bresolinii L.B. Sm. \& Downs, C. catamarcensis Ahumada, C. chamaepitys Baill., C. cinerellus Müll. Arg., C. echinulatus (Griseb.) Croizat, C. eskuchei Ahumada, C. gnaphalii Baill., C. isabellei Baill., C. julopsidium Baill., C. lachnostephanus Baill., C. laureltyanus Ahumada, C. leptophyllus Müll. Arg., C. paraguayensis Chodat, C.pycnocephalus Baill., C. ramellae Ahumada, C. serpyllifolius Baill., C. tartonraira Müll. Arg. Placed here with some uncertainty: $C$. santolinus Baill., C. tartonrairoides Pax \& K. Hoffm.

22. Croton sect. Luetzelburgiorum Riina, sect. nov. - Frutices stellati foliis marginibus glanduloso-dentatis, racemis terminalibus; staminibus 15; sepalis pistillatis valvatis, glandulosis; stylis multifidis. - Type: C. luetzelburgii Pax \& K. Hoffm.

Description. - Monoecious shrubs 0.5-2.5 m tall; indumentum stellate; leaves without glands at the base; margins entire to slightly dentate, with shortly stipitate glands on the apex of the teeth; venation pinnate; stipules fimbriate, glandular; inflorescences terminal, bisexual, lower cymules unisexual; stamens 15; sepals of pistillate flowers valvate, glandular; petals of pistillate flowers absent; styles multifid for a total of 12-15 stigmatic tips.

Distribution and habitat. - This monotypic section is restricted to the Chapada Diamantina of Bahia, Brazil, occurring in "campos rupestres" and high-elevation "cerrado", from 800 to $1800 \mathrm{~m}$.

Included species (1). - C. luetzelburgii Pax \& K. Hoffm.

23. Croton sect. Cleodora (Klotzsch) Baill., Étude Euphorb.: 369. 1858 Eleodora Klotzsch in Arch. Naturgesch. 7: 196. 1841 - Type: Cleodora sellowiana Klotzsch $\equiv$ Croton pachycalyx Müll. Arg. = C. sphaerogynus Baill.

= Croton sect. Stolidanthi Baill. in Adansonia 4: 323. $1864-$

Type: C. heterocalyx Baill., lectotype designated by Webster in Taxon 42: 800. 1993.

Description. - Monoecious trees and shrubs; indumentum stellate to stellate-lepidote; leaves with 2 glands at the base; margins entire; venation pinnate or palmate; stipules entire; inflorescences terminal, rarely axillary, bisexual; lower cymules bisexual, rarely unisexual, sometimes falsely unisexual; stamens 15-25; sepals of pistillate flowers partly to mostly connate at the base, aestivation imbricate or quincuncial; petals of pistillate flowers absent, rarely reduced; styles twice bifid or multifid for a total of 12 or more stigmatic tips; styles with varying degrees of connation, usually forming 1 or 3 columns at the top of the ovary.

Distribution and habitat. - Species of Croton sect. Cleodora inhabit moist or seasonally dry forests in tropical South America, Central America, and into central Mexico.

Notes. - Members of Croton sect. Cleodora share the synapomorphy of having styles that are fused into a column extending beyond the top of the ovary (Figs. $6 \mathrm{H}$ and $7 \mathrm{G}$ ). The section may be able to be divided into two equally sized 
groups by distinguishing those whose pistillate flowers have sepals that are mostly free, usually fleshy at the base, and with quincuncial aestivation, from those whose sepals of the pistillate flowers are not fleshy, usually united at least half of their length, and have imbricate aestivation (Caruzo, 2010; Caruzo $\&$ al., 2010). Croton cajucara is a widespread species in the Amazon basin that has an extensive history of ethnobotanical uses to treat diarrhea and other ailments (Le Cointe, 1934; Salatino \& al., 2007).

Included species (18). - C. billbergianus Müll. Arg., C. cajucara Benth., C. campanulatus Caruzo \& Cordeiro, C. fragrans Kunth, C. fragrantulus Croizat, $C$. hemiargyreus Müll. Arg., C. heterocalyx Baill., C. hoffmannii Müll. Arg., C. organensis Baill., C. orinocensis Müll. Arg., C.pseudofragrans Croizat, C. rottlerifolius Baill., C. rufolepidotus Caruzo \& Riina, C. salutaris Casar., C. sexmetralis Croizat, C. sphaerogynus Baill., C. spruceanus Benth., C. stellatoferrugineus Caruzo \& Cordeiro.

24. Croton sect. Cordiifolii Riina, sect. nov. - Frutices dioici stellati, foliis basi biglandulosis, stipulis linearibus; racemis axillaribus; staminibus 10 ad 12; sepalis pistillatis valvatis; stylis bifidis; fructibus muricatis. - Type: C. cordiifolius Baill.

Description. - Dioecious shrubs 0.5-2.0 m tall; indumentum stellate; leaves with 2 glands at the base; margins entire to serrulate; venation pinnate; stipules entire, linear; inflorescences axillary, unisexual; stamens 10-12; sepals of pistillate flowers valvate; petals of pistillate flowers absent; styles bifid, for a total of 6 stigmatic tips; fruits muricate.

Distribution and habitat. - This monotypic section is restricted to semiarid caatinga vegetation of Bahia, Brazil; it occurrs in seasonally semideciduous forests from 300 to $1000 \mathrm{~m}$. Included species (1). - C. cordiifolius Baill.

25. Croton sect. Eutropia (Klotzsch) Baill., Étude Euphorb.: 357. 1858 E Eutropia Klotzsch in Arch. Naturgesch. 7: 196. $1841 \equiv$ Croton subsect. Eutropia (Klotzsch) Müll. Arg. in Linnaea 34: 101. 1865 E Croton ser. Eutropia (Klotzsch) Müll. Arg. in Martius, Fl. Bras. 11(2): 87. 1873 - Type: C. polyandrus Spreng. E Eutropia brasiliensis Klotzsch, nom. illeg. \& superfl.

Description. - Monoecious shrubs or trees; indumentum lepidote to stellate-lepidote, plants nearly glabrous; leaves with 2 glands at the base; margins crenate, revolute; venation pinnate; stipules entire; inflorescences terminal and axillary, bisexual, lower cymules bisexual; stamens 10-15; sepals of pistillate flowers imbricate; petals of pistillate flowers absent or reduced; styles bifid for a total of 6 stigmatic tips.

Distribution and habitat. - Endemic to scrubby vegetation on sandy 'restinga' soils of eastern Brazil from sea level to $150 \mathrm{~m}$.

Notes. - The terminal and axillary inflorescences of C. polyandrus differ from other species of Croton with axillary inflorescences by being elongated, rather than contracted and congested as in $C$. sect. Eluteria and $C$. sect. Lasiogyne (C. alamosanus N.E. Rose and C. axillaris Müll. Arg.).

Included species (1). - C. polyandrus Spreng.
26. Croton sect. Geiseleria (A. Gray) Baill., Étude Euphorb.: 359. $1858 \equiv$ Croton subg. Geiseleria A. Gray, Manual, ed. 2: $391.1856 \equiv$ Geiseleria Klotzsch in Arch. Naturgesch. 7: 254. 1841, nom. illeg. - Type: Geiseleria glandulosa (L.) Klotzsch $\equiv C$. glandulosus L.

= Decarinium Raf., Neogenyton: $1.1825 \equiv$ Croton sect. Decarinium (Raf.) Müll. Arg. in Linnaea 34: 78. $1865 \equiv$ Croton subg. Decarinium (Raf.) Pax in Engler \& Prantl, Nat. Pflanzenfam. 3(5): 40. 1890 - Type: Decarinium glandulosum (L.) Raf. $\equiv$ C. glandulosus L.

= Aldinia Raf., Autik. Bot.: 50. 1840 - Type: A. glechomoides Raf. $=$ C. betulinus Vahl

= Pleopadium Raf., Autik. Bot.: 50. 1840 - Type: P. ciliatum Raf.

$=$ Ocalia Klotzsch in Arch. Naturgesch. 7: 195. $1841 \equiv$ Croton sect. Ocalia (Klotzsch) Baill., Étude Euphorb.: 366. 1858 - Type: C. perdicipes A. St.-Hil., lectotype designated by Baillon in Étude Euphorb.: 366. $1858=$ C. antisyphiliticus Mart.

= Podostachys Klotzsch in Arch. Naturgesch. 7: 193. $1841 \equiv$ Croton sect. Podostachys (Klotzsch) Baill., Étude Euphorb.: $365.1858 \equiv$ Croton subsect. Podostachys (Klotzsch) Müll. Arg. in Linnaea 34: 134. 1865 - Type: Podostachys subfloccosa Didr., lectotype designated by Wheeler in Taxon 24: 537. $1975=$ C. lundianus (Didr.) Müll. Arg.

=Brachystachys Klotzsch in London J. Bot. 2: 47. 1843 - Type: Brachystachys hirta (L'Hér.) Klotzsch $\equiv C$. hirtus L'Hér.

= Heterocroton S. Moore in Trans. Linn. Soc. London, Bot., ser. 2, 4: 461. $1895 \equiv$ Croton subg. Heterocroton (S. Moore) Pax in Engler \& Prantl, Nat. Pflanzenfam. Nachtr. 1: 211. 1897 - Type: Heterocroton mentiens S. Moore $\equiv$ C. mentiens (S. Moore) Pax.

$=$ Croton sect. Octolobium Chodat \& Hassl. in Bull. Herb. Boissier ser. 2, 5: 496. 1905 - Type: C. guaraniticus Chodat \& Hassl. = C. aberrans Müll. Arg.

Description. - Monoecious or dioecious herbs and shrubs, annual or perennial; indumentum stellate; leaves with 2 stalked (occasionally sessile or subsessile) glands at the base, alternate or opposite; margins dentate to serrate, often with stipitate glands in the sinuses; venation palmate to pinnate; stipules entire; inflorescences terminal, lower cymules unisexual; stamens 5-15; sepals of pistillate flowers usually unequal, aestivation open, valvate, or rarely reduplicate-valvate, sepals 5, 6 $(-10)$; petals of pistillate flowers absent (occasionally present); styles bifid or multifid for a total of 6, 12, or more stigmatic tips.

Distribution and habitat. - Fields, roadsides, waste places, open and mostly dry vegetation, deciduous to occasionally moist forests, widespread in the New World from the United States to Argentina, from sea level to $1800 \mathrm{~m}$. Croton glandulosus and $C$. hirtus have been introduced as weeds in Africa and Australia.

Notes. - Croton sect. Geiseleria has a high proportion of annual or short-lived species. With the additional groups included in synonymy here, it contains species with both bifid and multifid styles, although nearly all of them have pistillate flowers with unequal sepals (Fig. 7K-L), as well as a pair of stalked glands at the base of the leaves (Fig. 7D). 
Included species (82). - C. abaitensis Baill., C. aberrans Muell. Arg., C. adamantinus Müll. Arg., C. adenodontus (Müll. Arg.) Müll. Arg., C. agoensis Baill., C. antisyphiliticus Mart., C. araracuarae J. Murillo, P.E. Berry \& M.V. Arbeláez, C. arenosus Carn.-Torres \& Cordeiro, C. asperrimus Benth., C. betulinus Vahl, C. bidentatus Müll. Arg., C. brevipes Pax, C. carandaitensis Croizat, C. chamelensis E.J. Lott, C. chiribiquetensis Cardiel, C. comes Standl. \& L.O. Williams, C. crustulifer Croizat, C. cupulifer McVaugh, C. desertorum Müll. Arg., C. fluminensis (Kuntze) K. Schum., C. galeopsifolius Lanj., C. gardnerianus Baill., C. glandulosus L., C. glechomifolius Müll. Arg., C. goyazensis Müll. Arg., C. gracilescens Müll. Arg., C. grewioides Baill., C. grossedentatus Pittier, C. guildingii Griseb., C. gynopetalus Croizat, C. hadrianii Baill., C. harleyi Carn.-Torres \& Cordeiro, C. hirtus L'Hér., C. hostmannii Miq. ex Schltdl., C. inaequilobus Steyerm., $\boldsymbol{C}$. itzaeus Lundell, $C$. junceus Baill., $\boldsymbol{C}$. jutiapensis Croizat, C. krukoffianus Croizat, C. leptobotryus Müll. Arg., C. liebmannii Müll. Arg., C. longinervius Müll. Arg., C. lotorius Croizat, C. lundianus (Didr.) Müll. Arg., C. macradenis Görts \& Punt, C. macrodontus Müll. Arg., C. malvaviscifolius Millsp., C. martinianus V.W. Steinmann, C. mcvaughii G.L. Webster, C. megaponticus Müll. Arg., C. mentiens (S. Moore) Pax, C. mucronifolius Müll. Arg., C. nepetifolius Baill., C. odontadenius Müll. Arg., C. ortegae Standl., C. ortholobus Müll. Arg., C. pachysepalus Griseb., C. pardinus Müll. Arg., C. parodianus Croizat, C. pulegiodorus Baill., C. pycnadenius Müll. Arg., C. ramillatus Croizat, C. repens Schltdl., C. sclerocalyx (Didr.) Müll. Arg., C. sincorensis Mart. ex Müll. Arg., C. sipaliwinensis Lanj., C. spiraeifolius Jabl., C. strobiliformis Secco, C. subincanus Müll. Arg., C. sublepidotus Müll. Arg., C. subserratus Jabl., C. tamberlikii Müll. Arg., C. tetradenius Baill., C. teucridium Baill. C. triangularis Müll. Arg., C. trinitatis Millsp., $C$. varelae V.W. Steinmann, C. virgultosus Müll. Arg., C. waltherioides Urb., C. wittianus Ule, C. yacaensis Croizat. Placed here with some uncertainty: C. santaritensis Huft.

27. Croton sect. Barhamia (Klotzsch) Baill., Étude Euphorb.: 367. 1858 = Barhamia Klotzsch in Seemann, Bot. Voy. Herald 3: 104. 1853 - Type: Barhamia panamensis Klotzsch, lectotype designated by Wheeler in Taxon 24: 534. 1975 $=C$. hircinus Vent.

Description. - Monoecious or dioecious perennial herbs, subshrubs, or shrubs; indumentum stellate to lepidote; leaves without glands at the base; margins entire, crenulate, serrate, or dentate; venation pinnate or palmate; some species with viscid foliage; stipules glandular, glandular-lobed, dissected, or obsolete; inflorescences terminal, bisexual, lower cymules unisexual; inflorescence bracts glandular; stamens (3-)8-15(-20); sepals of pistillate flowers reduplicate-valvate or laciniate, glandular or eglandular; petals of pistillate flowers reduced or absent; styles multifid for a total of 12 or more stigmatic tips.

Notes. - Glandular inflorescence bracts are shared by all species of this otherwise diverse and variable section, in which pistillate flowers with glandular or dissected sepals are found in all of the subsections (Fig. 7H-I).

\section{Key to the subsections of Croton sect. Barhamia}

1. Dwarf subshrubs or perennial herbs; leaves $<1 \mathrm{~cm}$ long . . . . . . . . . . 27d. C. subsect. Micranthi

1. Shrubs; leaves $\geq 1 \mathrm{~cm}$ long . . . . . . . . . . 2

2. Leaf margins dentate or serrate . . . . . . . . 3

2. Leaf margins entire. . . . . . . . . . . . 4

3. Leaf venation palmate, evident or less commonly obscured; foliage of some species viscid; indumentum densely stellate to nearly glabrous; stipules glandular-lobed or dissected . . . . . . . . . 27a. C. subsect. Barhamia

3. Leaf venation pinnate, evident or obscured; foliage not viscid; indumentum densely stellate, stellate-lepidote, or sparse but not subglabrous; stipules glandular-lobed, dissected, or obsolete. . . . . . 27c. C. subsect. Medea

4. Leaves lepidote (rarely stellate); sepals of pistillate flowers eglandular; eastern Brazil 27e. C. subsect. Sellowiorum

4. Leaves stellate or stellate-lepidote; sepals of pistillate flowers glandular or dissected (rarely eglandular); more widely distributed................... 5

5. Leaf venation palmate or pinnate, indumentum sparse to appressed-stellate, but not woolly; Central America, Mexico, and the West Indies27b. C. subsect. Astraeopsis

5. Leaf venation pinnate, indumentum often wooly; Brazil, Paraguay, Uruguay, and Argentina. . . . . . . . . . . . . . . . . . . . . . . . . 27c. C. subsect. Medea

27a. Croton subsect. Barhamia (Klotzsch) B.W. van Ee, stat. nov. $\equiv$ Barhamia Klotzsch in Seemann, Bot. Voy. Herald 3: 104. 1853 - Type: Barhamia panamensis Klotzsch, lectotype designated by Wheeler in Taxon 24: 534. $1975=$ C. hircinus Vent.

$=$ Calypteriopetalon Hassk. in Flora 40: 531.1857 - Type: Calypteriopetalon brasiliense Hassk. $=$ Croton urticifolius Lam.

Description. - Indumentum stellate, loosely or appressedstellate, not woolly, to nearly glabrous; some species with viscid foliage; leaf margins serrate to dentate; venation palmate; stipules glandular-lobed or dissected; sepals of pistillate flowers valvate to reduplicate-valvate, glandular.

Distribution and habitat. - Croton subsect. Barhamia is widespread in the West Indies and Central and South America, with its greatest diversity in Brazil. It is found in mostly open, dry vegetation from 100 to $1200 \mathrm{~m}$.

Notes. - Although Martínez Gordillo \& Espinosa Matías (2005) included Croton agoensis Baill. in C. sect. Barhamia, which corresponds to our concept of $C$. subsect. Barhamia, the presence of stipitate glands at the base of the leaves and the lack of glands on the inflorescence bracts exclude it from the section, and its overall morphology is instead consistent with C. sect. Geiseleria.

Included species (19). - C. adenocalyx Baill., C. betulaster Müll. Arg., C. catariae Baill., C. chaetocalyx Müll. Arg., C. essequiboensis Klotzsch, C. glandulosodentatus Pax \& K. Hoffm., C. glutinosus Müll. Arg., C. guianensis Aubl., C. hircinus Vent., C. klaenzei Müll. Arg., C. longibracteatus M.J. Martínez Gordillo \& de Luna, C. muscicapa Müll. 
Arg., C. paucistamineus Müll. Arg., C. perviscosus Croizat, C. rhexiifolius Baill., C. rudolphianus Müll. Arg., C. senescens Croizat, C. urticifolius Lam., C. yerbalium Chodat \& Hassl.

27b. Croton subsect. Astraeopsis (Baill.) B.W. van Ee, stat. nov. $\equiv$ Croton sect. Astraeopsis Baill., Étude Euphorb.: 362. 1858.

Description. - Indumentum appressed-stellate, dense to sparse; foliage not viscid; leaf margins entire; venation palmate or pinnate; stipules glandular-lobed or linear; sepals of pistillate flowers reduplicate-valvate, entire or glandular.

Distribution and habitat. - West Indies and the Yucatan peninsula of Mexico and adjacent parts of Belize. Open, scrubby vegetation, usually on limestone, from sea level to $300 \mathrm{~m}$.

Included species (4). - C. ameliae Lundell, C. glabellus L., C. glandulosepalus Millsp., C. sutup Lundell.

27c. Croton subsect. Medea (Klotzsch) Pax in Engler \& Prantl, Nat. Pflanzenfam. 3(5): 39. $1890 \equiv$ Medea Klotzsch in Arch. Naturgesch. 7: 193. $1841 \equiv$ Croton sect. Medea (Klotzsch) Baill., Étude Euphorb.: 368. $1858 \equiv$ Croton ser. Medea (Klotzsch) Müll. Arg. in Martius, Fl. Bras. 11(2): 144. 1873 - Type: Medea hirta Klotzsch = C. timandroides (Didr.) Müll. Arg.

= Timandra Klotzsch in Arch. Naturgesch. 7: 197. $1841-$ Type: Croton serratus Müll. Arg., lectotype designated by Wheeler in Taxon 24: 538. 1975.

$=$ Myriogomphos Didr. in Vidensk. Meddel. Dansk Naturhist. Foren. Kjobenhavn 1857: 142. 1857 - Type: Myriogomphos fuscus Didr. $\equiv$ C. fuscus (Didr.) Müll. Arg.

$=$ Croton sect. Codonocalyx Klotzsch ex Baill., Étude Euphorb.: 369. 1858 - Type: C. montevidensis Spreng., lectotype designated by Webster in Taxon 42: 820. 1993.

$=$ Croton sect. Hesperidium Baill. in Adansonia 4: 306. 1864 - Type: C. matronalis Baill., lectotype designated by Webster in Taxon 42: 818. $1993=$ C. vestitus Spreng.

$=$ Croton sect. Calycireduplicati Allem in Bol. Soc. Argent. Bot. 18: 76. 1979 - Type: Croton calycireduplicatus Allem.

Description. - Indumentum stellate to stellate-lepidote, often woolly; foliage not viscid; leaf margins entire to serrate; venation pinnate, often obscure; stipules glandular, glandularlobed, dissected, or obsolete; sepals of pistillate flowers laciniate, or reduplicate-valvate and glandular, entire, or dentate.

Distribution and habitat. - Brazil, Paraguay, Uruguay, and Argentina; temperate and subtropical, generally open vegetation, from sea level to $1000 \mathrm{~m}$.

Notes. - In the classification adopted here, species with pistillate flowers with both reduplicate-valvate and laciniate calyces are included in $C$. subsect. Medea.

Included species (45). - C. arlineae D. Medeiros, L. Senna \& R.J.V. Alves, C. atrorufus Müll. Arg., C. avulsus Croizat, C. berberifolius Croizat, C. borbensis Secco \& P.E. Berry, C. calyciglandulosus Allem, C. calycireduplicatus Allem, C. chaetophorus Müll. Arg., C. cuchillae-nigrae Croizat, C. decipiens Baill., C. dissectistipulatus Secco, C. eremophilus Müll. Arg., C. faroensis Secco, C. fuscus (Didr.)
Müll. Arg., C. garckeanus Baill., C. glandulosobracteatus Carn.-Torres \& Cordeiro, C. gnidiaceus Baill., C. helichrysum Baill., C. heterodoxus Baill., C. integrilobus Croizat, C. josephinus Müll. Arg., C. landoltii Ahumada, C. langsdorffii Müll. Arg., C. lenheirensis D. Medeiros, L. Senna \& R.J.V. Alves, C. luzianus Müll. Arg., C. megalocalyx Müll. Arg., C. melanoleucus Müll. Arg., C. montevidensis Spreng., C. parvifolius Müll. Arg., C. pradensis D. Medeiros, L. Senna \& R.J.V. Alves, C. quintasii Allem, C. ramboi Allem, C. rubiginosus Croizat, C. serratifolius Baill., C. serratoideus Radcl.-Sm. \& Govaerts, C. serratus (Klotzsch) Müll. Arg., C. siderophyllus Baill., C. spica Baill., C. staechadis Baill., C. subdioecus (Kuntze) K. Schum., C. subglaber (Kuntze) K. Schum., C. timandroides (Didr.) Müll. Arg., C. vestitus Spreng. Placed here with some uncertainty: $C$. arirambae Huber, C. thymelinus Baill.

27d. Croton subsect. Micranthi (Baill.) B.W. van Ee, stat. nov. $\equiv$ Croton sect. Micranthi Baill., Étude Euphorb.: 355. 1858 - Type: C. galeottianus Baill. $=C$. nummulariifolius A. Rich.

$=$ Merleta Raf., Autik. Bot.: 49. 1840 - Type: Merleta microphylla Raf. $=$ C. nummulariifolius A. Rich.

$=$ Comatocroton H. Karst. in Wochenschr. Gärtnerei Pflanzenk. 2: 6. 1859 - Type: Comatocroton ovalifolia (Vahl in H. West) H. Karst. 三 Croton ovalifolius Vahl in H. West.

$=$ Croton sect. Microcroton Griseb. in Mem. Amer. Acad. Arts ser. 2, 8: 159. 1860 - Type: C. serpylloides Griseb. = C. nummulariifolius A. Rich.

Description. - Indumentum appressed-stellate; foliage not viscid; leaf margins entire; venation palmate or pinnate; stipules glandular-lobed; sepals of pistillate flowers reduplicatevalvate, glandular, or valvate and entire.

Distribution and habitat. - Mexico, West Indies, and Central and South America; sand barrens, coastal regions, waste places, and other open vegetation, from sea level to $1500 \mathrm{~m}$.

Notes. - Webster (1993) suggested that what he recognized as Croton sect. Micranthi could perhaps be treated as a subsection of $C$. sect. Barhamia, and the molecular data support this.

Included species (13). - C. cerinus Müll. Arg., C. gonaivensis Urb. \& Ekman, C. haitiensis P.T. Li, C. lombardianus Croizat, C. microcarpus Ham., C. microphyllinus Radcl.-Sm. \& Govaerts, C. nummulariifolius A. Rich., C. nummularius Baill., C. ovalifolius Vahl, C. paludosus Müll. Arg., C. radlkoferi Pax \& K. Hoffm., C. refractus Müll. Arg., C. velutinus Baill.

27e. Croton subsect. Sellowiorum B.W. van Ee, subsect. nov. - Frutices lepidotis vel stellatis, foliis integris; stipulis bracteisque glanduloso-lobatis; sepalis pistillatis reduplicato-valvatis, integris, eglandulosis. - Type: C. sellowii Baill.

Description. - Indumentum lepidote or stellate; foliage not viscid; leaf margins entire; venation pinnate, obscure; stipules glandular-lobed; sepals of pistillate flowers reduplicate-valvate, entire, eglandular. 
Distribution and habitat. - Sandy soils in open vegetation in eastern Brazil. Croton sellowii Baill. occurrs at lower elevations in "restinga" vegetation from sea level to $100 \mathrm{~m}$. Croton myrsinites Baill. and C. schultesii Müll. Arg. occupy "campo rupestre" habitats from 800 to $1500 \mathrm{~m}$.

Notes. - Müller (1873) placed Croton sellowii in C. ser. Argyroglossum, with which it shares pistillate flowers with reduplicate-valvate sepals (Fig. 7J), but it keyed out by itself given its glandular stipules. Although these species are unusual in C. sect. Barhamia for being at least partly lepidote amid otherwise stellate species, the glandular inflorescence bracts and stipules of these three species are shared with the rest.

Included species (3). - C. myrsinites Baill., C. schultesii Müll. Arg., C. sellowii Baill.

28. Croton sect. Luntia (Neck. ex Raf.) G.L. Webster in Taxon 42: 804. 1993 ELuntia Neck. ex Raf., Sylva Tellur.: 62. 1838

$\equiv$ Croton subsect. Matourenses G.L. Webster in Taxon 42: 804. 1993 - Type: C. matourensis Aubl. $\equiv$ C. sericeus Lam., nom. illeg. $\equiv$ Luntia sericea Raf., nom. illeg.

$=$ Croton subsect. Palanostigma Mart. ex Baill., Étude Euphorb.: 358. 1858 - Type: C. palanostigma Klotzsch.

Description. - Monoecious shrubs, trees, or lianas, 3-25 $\mathrm{m}$ tall; indumentum lepidote or stellate; leaves with 2 glands at the base, lamina entire or lobed, sometimes with cup-shaped glands; margins entire; venation palmate or pinnate; stipules entire; inflorescences terminal, bisexual or unisexual, lower cymules bisexual or unisexual; stamens 10-15; sepals of pistillate flowers valvate to reduplicate; petals of pistillate flowers reduced or absent; styles multifid for a total of 18-36 stigmatic tips.

Distribution and habitat. - Croton sect. Luntia is widespread across tropical South America and extends into Central America in Panama, Costa Rica, and Nicaragua. Its members are found in primary to secondary moist forests and disturbed sites, often near streams, from sea level to $3000 \mathrm{~m}$.

Notes. - Croton ascendens Secco \& N.A. Rosa, C. grazielae Secco, C. javarisensis Secco, C. pullei Lanj. and C. nuntians Croizat represent a shift from the typical free-standing habit found in nearly all species of Croton to a semi-self-supporting liana growth form (Medeiros Carreira \& al., 1996; Gallenmüller \& al., 2001, 2005). Although none of these have been sampled molecularly, the lobed leaves and cup-shaped laminar glands of C. ascendens and C. nuntians are very similar to those of C. palanostigma, and we expect that they are closely related. The other lianas have unlobed leaves and lack the cup-shaped glands, suggesting that there may have been more than one shift to the liana habit within $C$. sect. Luntia.

Included species (19). - C. ascendens Secco \& N.A. Rosa, C. caryophyllus Benth., C. cearensis Baill., C. chocoanus Croizat, C. costatus Kunth, C. grazielae Secco, C. huitotorum Croizat, C. javarisensis Secco, C. killipianus Croizat, C. matourensis Aubl., C. megalodendron Müll. Arg., C. nuntians Croizat, C. palanostigma Klotzsch, C. perimetralensis Secco, C. pullei Lanj., C. skutchii Standl., C. smithianus Croizat, C. tonantinensis Jabl., C. uribei Croizat.
29. Croton sect. Julocroton (Mart.) G.L. Webster in J. Arnold Arbor. 48: 354. $1967 \equiv$ Julocroton Mart. in Flora 20 (2, Beibl.): 119. $1837 \equiv$ Croton subg. Julocroton (Mart.) Radcl.-Sm. \& Govaerts in Kew Bull. 52: 184. 1997 - Type: Julocroton phagedaenicus Mart. $=$ C. triqueter Lam.

$=$ Cieca Adans., Fam. Pl. 2: 355. 1763, nom. rej.

$=$ Heterochlamys Turcz. in Bull. Soc. Imp. Naturalistes Moscou 16: 61.1843 - Type: Heterochlamys quinquinervia Turcz. $=C$. argenteus $\mathrm{L}$.

$=$ Julocroton subg. Eremadenia Didr. in Vidensk. Meddel. Dansk Naturhist. Foren. Kjobenhavn 1857: 134. 1857 Type: J. triqueter (Lam.) Didr. $\equiv C$. triqueter Lam.

$=$ Julocroton subg. Oligonychia Didr. in Vidensk. Meddel. Dansk Naturhist. Foren. Kjobenhavn 132. 1857 - Type: J. argenteus $(\mathrm{L}$.$) Didr. \equiv C$. argenteus L., lectotype designated by Webster in Novon 2: 270. 1992.

$=$ Centrandra Karst. in Linnaea 28: 440. 1857 - Type: Centrandra hondensis Karst. $\equiv C$. hondensis (Karst.) G.L. Webster.

Description. - Monoecious herbs or shrubs; indumentum stellate; leaves without glands at the base; margins entire or dentate; venation palmate or pinnate; stipules entire to laciniate; inflorescences terminal, bisexual, congested, lower cymules unisexual; stamens 10-12; sepals of pistillate flowers laciniate and unequal, valvate to reduplicate-valvate; petals of pistillate flowers reduced or absent; styles multifid, occasionally bifid, for a total of 12 , or occasionally 6 , stigmatic tips.

Distribution and habitat. - This is a primarily South American group with its greatest diversity in Brazil, but a few species extend into the rest of tropical South America, and one species, $C$. argenteus, extends throughout Central America, the Caribbean, and up to the southern United States. It has a somewhat disjunct distribution between eastern and western South America (Cordeiro, 1990). Species of the section are found in open, generally dry vegetation from sea level to $2000 \mathrm{~m}$.

Notes. - The congested inflorescences and pistillate flowers with highly dissected and unequal sepals make this one of the easier sections to recognize (Fig. 7E).

Included species (41). - C. abutilopsis G.L. Webster, C. ackermannianus (Müll. Arg.) G.L. Webster, C. acuminatissimus (Pittier) G.L. Webster, C. agrestis (Pax \& K. Hoffm.) Radcl.-Sm. \& Govaerts, C. allemii G.L. Webster, C. apostolon Radcl.-Sm. \& Govaerts, C. argentealbidus Radcl.-Sm. \& Govaerts, C. argenteus L., C. calonervosus G.L. Webster, C. chodatii (Croizat) P.E. Berry, C. conspurcatus Schltdl., C. cooperianus (Croizat) Radcl.-Sm. \& Govaerts, C. doratophylloides (Croizat) G.L. Webster, C. doratophyllus Baill., C. flavispicatus Rusby, C. fuscescens Spreng., C. geraesensis (Baill.) G.L. Webster, C. herzogianus (Pax \& K. Hoffm.) Radcl.-Sm. \& Govaerts, C. hondensis (G. Karst.) G.L. Webster, C. lepidus (S. Moore) Radcl.-Sm. \& Govaerts, C. malvoides (Croizat) Radcl.-Sm. \& Govaerts, C. nigricans (Mart. ex Schltdl.) Radcl.-Sm. \& Govaerts, C. phyllanthus (Chodat \& Hassl.) G.L. Webster, C. pyrosoma (Croizat) Radcl.-Sm. \& Govaerts, C. robustior (L.B. Sm. \& Downs) Radcl.-Sm. \& Govaerts, C. rupestris (Chodat \& Hassl.) G.L. Webster, C. rutilus (Chodat \& Hassl.) G.L. Webster, C. salzmannii 
(Baill.) G.L. Webster, C. solanaceus (Müll. Arg.) G.L. Webster, C. spissirameus Radcl.-Sm. \& Govaerts, C. stipularis (Müll. Arg.) G.L. Webster, C. subpannosus Müll. Arg. ex Griseb., C. thellungianus (Herter ex Arechav.) Radcl.-Sm. \& Govaerts, C. tocantinsensis Radcl.-Sm. \& Govaerts, C. trichophilus (Pax \& K.Hoffm.) Radcl.-Sm. \& Govaerts, C. triqueter Lam., C. verbascoides G.L. Webster, C. vergarenae (Jabl.) Gillespie, C. villosissimus (Chodat \& Hassl.) Radcl.-Sm. \& Govaerts, C. viridulus (Croizat) Radcl.-Sm. \& Govaerts. Placed here with some uncertainty: C. calocephalus Müll. Arg.

30. Croton sect. Lasiogyne (Klotzsch) Baill., Étude Euphorb.: 370. 1858 E Lasiogyne Klotzsch in Nov. Actorum Acad. Caes. Leop.-Carol. Nat. Cur. 19 (Suppl. 1): 418. $1843 \equiv$ Croton subsect. Lasiogyne (Klotzsch) Müll. Arg. in Linnaea 34: 81 (95). 1865 - Type: Lasiogyne brasiliensis Klotzsch =C. compressus Lam.

=Croton sect. Gonocladium Baill. in Adansonia 4: 299. 1864 $\equiv$ Croton ser. Gonocladium (Baill.) Müll. Arg. in Martius, Fl. Bras. 11(2): 126. 1873 E Croton subsect. Gonocladium (Baill.) Pax in Engler \& Prantl, Nat. Pflanzenfam. 3(5): 39. 1890 - Type: C. compressus Lam.

= Croton sect. Argyroglossum Baill. in Adansonia 4: 289. 1864 $\equiv$ Croton ser. Argyroglossum (Baill.) Müll. Arg. in Martius, Fl. Bras. 11(2): 118. $1873 \equiv$ Croton subsect. Argyroglossum (Baill.) Pax in Engler \& Prantl, Nat. Pflanzenfam. 3(5): 39. 1890 - Type: C. argyroglossum Baill. = C. argyrophyllus Kunth.

=Croton sect. Decalobium Müll. Arg. in Linnaea 34: 78. 1865 $\equiv$ Croton subg. Decalobium (Müll. Arg.) Pax in Engler \& Prantl, Nat. Pflanzenfam. 3(5): 40. 1890 - Type: C. decalobus Müll. Arg.

= Croton sect. Anadenocroton G.L. Webster in Taxon 42: 806. 1993 - Type: C. axillaris Müll. Arg.

Description. - Monoecious shrubs and trees; indumentum stellate to lepidote; leaves without glands at the base; margins entire although frequently with crenations at the base on either side of the petiole; venation palmate or pinnate; stipules entire; inflorescences terminal or axillary, bisexual or unisexual, lower cymules unisexual; stamens 10-20; sepals of pistillate flowers reduplicate-valvate, occasionally just valvate; petals of pistillate flowers reduced or absent; styles multifid, free or sometimes basally connate, for a total of approximately 24 stigmatic tips.

Distribution and habitat. - Croton sect. Lasiogyne is widespread in the New World tropics and subtropics, occurring mostly in dry forest and scrub vegetation, from sea level to $1000 \mathrm{~m}$.

Notes. - Croton sect. Lasiogyne is circumscribed here more inclusively than how Baillon (1858, 1864), Müller (1865, 1873), and Webster (1993) treated it. Webster (1993) recognized C. sect. Argyroglossum as distinct from C. sect. Lasiogyne based on lepidote pubescence in the former and stellate pubescence in the latter, but this distinction is not supported by the molecular data. The reduplicate-valvate sepals of the pistillate flowers of most species (Fig. 7F) are the most readily recognized characteristic of this section, although these are shared homoplasiously with some species of $C$. sects. Barhamia (Fig. 7J), Cleodora, Cyclostigma, Luntia (Fig. 7D), and Prisci (Fig. 6I). Webster (1993) indicated that $C$. sect. Decalobium was highly suggestive of $C$. sect. Barhamia, and Martínez Gordillo \& Espinosa Matías (2005) effectively synonymized the two by including $C$. decalobus, the type of $C$. sect. Decalobium, in $C$. sect. Barhamia. However, DNA sequence data (Van Ee, 2006) place $C$. decalobus and $C$. pendens within a more broadly circumscribed $C$. sect. Lasiogyne. Whether this broader sectional concept can be maintained as a monophyletic group, and what subsections can be recognized within it, will require additional phylogenetic and taxonomic work.

Included species (45). - C. acapulcensis M.J. Martínez Gordillo \& J. Jiménez Ram., C. alamosanus Rose, C. anomalus Pittier, $\boldsymbol{C}$. argyrophyllus Kunth, $\boldsymbol{C}$. astroites Dryand., $\boldsymbol{C}$. atrostellatus V.W. Steinmann, C. axillaris Müll. Arg., C. blanchetianus Baill., C. bolivarensis Croizat, C. chiapensis Lundell, C. compressus Lam., C. cucutensis Croizat, C. culiacanensis Croizat, C. curranii S.F. Blake, C. decalobus Müll. Arg., C. deserticola Steyerm., C. floribundus Spreng., C. heliaster S.F. Blake, C.jacobinensis Baill., C.janeirensis Radcl.-Sm. \& Govaerts, C. katoae Croizat, C. limae A.P.S. Gomes, P.E. Berry \& M.F. Sales, C. mansfeldii Urb., C. masonii I.M. Johnst., C. micans Sw., C. moustiquensis Urb., C. pendens Lundell, C. potaroensis Lanj., C. rosmarinoides Millsp., C. sacaquinha Croizat, C. scaber Willd., C. schomburgkianus A.P.S. Gomes \& M.F. Sales, C. sidifolius Lam., C. spiralis Müll. Arg., C. subcompressus Müll. Arg., C. sucrensis Steyerm., C. tabascensis Lundell, C. tricolor Klotzsch ex Baill., C. umbratilis Kunth, C. watsonii Standl., C. yucatanensis Lundell. Placed here with some uncertainty: C. astrophorus Urb., C. claussenianus Baill., C. coronatus Urb., C. stahelianus Lanj.

31. Croton sect. Heptallon (Raf.) Müll. Arg. in Linnaea 34: 78. $1865 \equiv$ Anisepta Raf., First Cat. Gard. Transylv. Univ.: 13. 1824, nom. inval. $\equiv$ Heptallon Raf., Neogenyton: 1.1825 $\equiv$ Heptanis Raf., Neogenyton: 1. 1825, nom. superfl. $\equiv$ Croton subg. Heptallon (Raf.) Pax in Engler \& Prantl, Nat. Pflanzenfam. 3(5): 40. 1890 - Type: Heptallon graveolens Raf. $\equiv C$. capitatus Michx.

$=$ Pilinophytum Klotzsch in Arch. Naturgesch. 7: 255. $1841 \equiv$ Croton subg. Pilinophytum (Klotzsch) A. Gray, Manual, ed. 2: 391. 1856 - Type: Pilinophytum capitatum (Michx.) Klotzsch $\equiv C$. capitatus Michx.

=Engelmannia Klotzsch in Arch. Naturgesch. 7: 253. 1841, nom. illeg. non Engelmannia A. Gray ex Nutt., 1840 (Asteraceae) $\equiv$ Angelandra Endl., Gen. Pl. Suppl. 5: 91. 1850, nom. illeg. non Angelandra Endl., 1843 (Asteraceae) 三Croton sect. Angelandra Müll. Arg. in Linnaea 34: 79. $1865 \equiv$ Croton subg. Angelandra (Müll. Arg.) Pax in Engler \& Prantl, Nat. Pflanzenfam. 3(5): 40. 1890 = Gynamblosis Torr. in Marcy, Explor. Red River Louisiana 295. 1853 三 Croton subg. Gynamblosis (Torr.) A. Gray, Manual, ed. 2: 392. 1856 - Type: Engelmannia nuttaliana Klotzsch, nom. illeg. $=$ C. monanthogynus Michx.

Description. - Monoecious herbs or subshrubs, annual or perennial; indumentum stellate to stellate-lepidote; leaves 
without glands at the base; margins entire; venation pinnate; stipules entire, sometimes absent; inflorescences terminal or terminal and axillary, bisexual or unisexual, lower cymules unisexual; stamens 4-15; sepals of pistillate flowers valvate, occasionally unequal, aestivation occasionally open; petals of pistillate flowers absent; styles bifid or twice bifid for a total of (4) 6-12 stigmatic tips; columella usually tipped with 3 recurved appendages; ovary 2-carpellate in one species.

Distribution and habitat. - Eastern, central, and southern United States to central Mexico. Pastures, roadsides, sand dunes, deserts, and disturbed areas, from sea level to $1800 \mathrm{~m}$.

Notes. - This section of eight annual species and a single perennial species, C. pottsii, is endemic to North America. Like some other sections, it includes closely related species with bifid and twice bifid styles, indicating the ease with which these characters can change within Croton. Van Ee \& Berry (2010a) provide a more detailed phylogeny of this section, a list of the extensive synonymy, and an explanation for why its correct name is sect. Heptallon, as it was called by Webster (1967), rather than "section Pilinophytum", as it was treated by Webster (1993).

Included species (9). - C. capitatus Michx., C. elliottii Chapm., C. heptalon (Kuntze) B.W. van Ee \& P.E. Berry, C. leucophyllus Müll. Arg., C. lindheimeri (Engelm. \& A. Gray) Alph. Wood., C. lindheimerianus Scheele, C. monanthogynus Michx., C. palmeri S. Watson, C. pottsii (Klotzsch) Müll. Arg.

\section{Accepted species of unknown affinity}

Croton abonari Riina \& P.E. Berry, C. amazonicus Müll. Arg., C. astianus Croizat, C. boissieri Müll. Arg., C. carinatus Müll. Arg., C. confinis L.B. Sm. \& Downs, C. guaiquinimae Steyerm., C. ichthygaster L.B. Sm. \& Downs, C. microgyne Croizat, C. scutatus P.E. Berry (10 in total).

These are all distinctive species, with either anomalous characters that require further evaluation, or in need of more material that might provide additional characters to help place them.

Total number of New World species recognized: 712.

\section{aCKNOWLEDGEMENTS}

We are grateful to the numerous colleagues who have provided samples and facilitated field work, as well as to the curators of the herbaria cited in the Appendix who allowed us to sample specimens. This work was supported by NSF grants DEB-0212481 to P.E. Berry and DEB-0508725 to P.E. Berry \& B. van Ee, grants from the Latin American Caribbean \& Iberian studies (LACIS) program of the University of Wisconsin-Madison to R. Riina \& B. van Ee, an award from the International Association of Plant Taxonomy (IAPT), the American Society of Plant Taxonomists (ASPT), and the Lawrence Memorial Award of the Hunt Institute to R. Riina, and by support from the University of Michigan Department of Ecology and Evolutionary Biology. We thank the three anonymous reviewers for their extensive and useful comments.

\section{LITERATURE CITED}

Angiosperm Phylogeny Group. 2009. An update of the Angiosperm Phylogeny Group classifcation for the orders and families of flowering plants: APG III. Bot. J. Linn. Soc. 161: 105-121.

Baillon, H. 1858. Étude générale du groupe des Euphorbiacées. Paris: Masson.

Baillon, H. 1864. Species Euphorbiacearum. Euphorbiacées Américaines. Première partie: Amérique austro-orientale. Adansonia 4: 257-377.

Berry, P.E., Hipp, A.L., Wurdack, K.J., Van Ee, B. \& Riina, R. 2005. Molecular phylogenetics of the giant genus Croton and tribe Crotoneae (Euphorbiaceae sensu stricto) using ITS and trnL-trnF DNA sequence data. Amer. J. Bot. 92: 1520-1534.

Berry, P.E., Riina, R., Van Ee, B. \& Haber, E. 2009. The radiation of Croton (Euphorbiaceae) on Madagascar-how did this group become so speciose and diversified there compared to other Old World areas? Botany \& Mycology 2009, Snowbird, Utah, July 25-29, Abstract. http://2009.botanyconference.org/engine/search/index.php? func $=$ detail\&aid $=816$.

Britton, N.L. 1918. Flora of Bermuda. New York: Charles Scribner's Sons.

Brown, J.M. \& Lemmon, A.R. 2007. The importance of data partitioning and the utility of Bayes Factors in Bayesian phylogenetics. Syst. Biol. 56: 643-655.

Brown, N.E. 1883. The "Genera Plantarum." Gard. Chron., II, 19: $733-734$.

Caruzo, M.B.R. 2010. Sistemática de Croton sect. Cleodora (Euphorbiaceae s.s.). Dissertation, Universidade de São Paulo, Brasil.

Caruzo, M.B.R., Cordeiro, I., Berry, P.E. \& Riina, R. 2010. A new species of Croton section Cleodora (Euphorbiaceae s.s.) from Minas Gerais, Brazil. Phytotaxa 3: 27-33.

Cho, Y., Mower, J.P., Qiu, Y.-L. \& Palmer, J.D. 2004. Mitochondrial substitution rates are elevated and variable in a genus of flowering plants. Proc. Natl. Acad. Sci. U.S.A. 101: 17741-17746.

Cordeiro, I. 1990. Aspectos taxonômicos e distribuição geográfica de Julocroton Mart. (Euphorbiaceae). Acta Bot. Brasil. 4: 83-90.

Cordeiro, I., Berry, P.E., Caruzo, M.B.R. \& Van Ee, B. 2008. Croton laceratoglandulosus (Euphorbiaceae s.s.), a new glandular-stipulate species from Brazil and Bolivia, and its systematic position based on molecular analysis. Bot. J. Linn. Soc. 158: 493-498.

Croizat, L. 1942. New and critical Euphorbiaceae chiefly from the southeastern United States. Bull. Torrey Bot. Club 69: 445-460.

De Queiroz, A., Donoghue, M.J. \& Kim, J. 1995. Separate versus combined analysis of phylogenetic evidence. Annual Rev. Ecol. Syst. 26: 657-681.

Frodin, D.G. 2004. History and concepts of big plant genera. Taxon 53: 753-776.

Gallenmüller, F., Müller, U., Rowe, N. \& Speck, T. 2001. The growth form of Croton pullei (Euphorbiaceae) - functional morphology and biomechanics of a neotropical liana. Pl. Biol. (Stuttgart) 3: $50-61$.

Gallenmüller, F., Rowe, N. \& Speck, T. 2005. Development and growth form of the neotropical liana Croton nuntians: The effect of light and mode of attachment on the biomechanics of the stem. J. Pl. Growth Regulat. 23: 83-97.

Ginzbarg, S. 1992. A new disjunct variety of Croton alabamensis (Euphorbiaceae) from Texas. Sida 15: 41-52.

Gomes, A.P.S. 2006. Revisão das espécies sul-americanas de Croton sect. Argyroglossum Baill. (Crotonoideae-Euphorbiaceae). Dissertation, Universidade Federal Rural de Pernambuco, Brasil.

González Ramírez, J. \& Poveda Álvarez, L. 2003. Dos nuevas especies de Croton (Euphorbiaceae) en el neotrópico. Lankesteriana 8: 7-12.

Govaerts, R., Frodin, D.G. \& Radcliffe-Smith, A. 2000. World checklist and bibliography of Euphorbiaceae (and Pandaceae), 4 vols. Kew: Royal Botanic Gardens. 
Grisebach, A.H.R. 1859. Flora of the British West Indian Islands. London: Reeve.

Haber, E., Van Ee, B., Oyserman, B. \& Berry, P.E. 2010. Origin and diversification of Croton (Euphorbiaceae) in Madagascar, and the Mascarene and Comoros islands. Botany 2010, Providence, Rhode Island, July 31-August 4. Abstract. http://2010.botanyconference .org/engine/search/index.php? func=detail\&aid=535.

Huelsenbeck, J.P. \& Ronquist, F. 2001. MrBayes: Bayesian inference of phylogenetic trees. Bioinformatics 17: 754-755.

Klotzsch, J.F. 1853. Euphorbiaceae. Pp. 99-106 in: Seemann, B.C. (ed.), Botany of the voyage of H.M.S. Herald ... during the years 1845-1851. London: Reeve.

Knoop, V. 2004. The mitochondrial DNA of land plants: Peculiarities in phylogenetic perspective. Curr. Genet. 46: 123-139.

Le Cointe, P. 1934. Arvores e plantas úteis (indigenas e aclimatadas). Belém: Livraria Clássica.

Leandri, J. 1939. Les Croton de Madagascar et des îles voisines. Ann. Inst. Bot.-Géol. Colon. Marseille 7: 1-100.

León Enríquez, B.L. 2007. Caracterización arquitectónica, molecular y cromosómica del género Croton sección Eluteria (Euphorbiaceae). Dissertation, Colegio de la Frontera Sur, Chetumal, Mexico.

León Enríquez, B.L. \& Martínez Gordillo, M. 2008. Especie nueva de Croton sección Eluteria (Euphorbiaceae) de Chiapas, México. Novon 18: 189-191.

León Enríquez, B.L. \& Vester, H.F.M. 2006. Croton mayanus (section Eluteria: Euphorbiaceae), a new species, endemic to the Yucatán Península, México. Novon 16: 505-507.

Lima, L.R. 2006. Estudos taxonômicos em Croton seção Lamprocroton (Müll. Arg.) Pax (Euphorbiaceae). Dissertation, Universidade de São Paulo, Brasil.

Lima, L.R. \& Pirani, J.R. 2008. Revisão taxonômica de Croton sect. Lamprocroton (Müll. Arg.) Pax (Euphorbiaceae s.s.). Biota Neotrop. (Sao Paulo) 8: 203-257.

Maddison, D.R. \& Maddison, W.P. 2005. MacClade: Analysis of Phylogeny and Character Evolution. Version 4.08. Sunderland, Massachusetts: Sinauer.

Martínez Gordillo, M. 1996. El género Croton (Euphorbiaceae) en Mesoamerica. Thesis, Universidad Nacional Autónoma de México, Mexico City.

Martínez Gordillo, M. \& Cruz Durán, R. 2002. Especie nueva de la sección Eluteria Griseb. del género Croton (Euphorbiaceae) de Veracruz, México. Anal. Inst. Biol. Univ. Nac. Autón. México, Bot. 73: 141-145.

Martínez Gordillo, M. \& Espinosa Matías, S. 2005. Tricomas foliares de Croton sección Barhamia (Euphorbiaceae). Acta Bot. Mex. 72: 39-51.

Medeiros Carreira, L.M., de Souza Secco, R. \& Barth, O.M. 1996. Pollen morphology of the lianescent species of the genus Croton (Euphorbiaceae). Grana 35: 74-78.

Müller, J. 1865. Euphorbiaceae. Vorläufige Mittheilungen aus dem für De Candolle's Prodromus bestimmten Manuscript über diese Familie [conclusion]. Linnaea 34: 1-224.

Müller, J. 1866. Euphorbiaceae. Pp. 189-1261 in: Candolle, A.P. de (ed.), Prodromus systematis naturalis regni vegetabilis, vol. 15(2). Paris, Strasbourg, \& London: Treuttel \& Würtz.

Müller, J. 1873. Croton. Pp. 81-274 in: Martius, C.F.P. von, Flora Brasiliensis, vol. 11(2). Munich, Vienna \& Leipzig.

Nixon, K.C. \& Carpenter, J.M. 1996. On simultaneous analysis. Cladistics 12: 221-241.

Pax, F. 1890. Crotoneae. Pp. 36-41 in: Engler, A. \& Prantl, K. (eds.), Die natürlichen Pflanzenfamilien, vol. 3(5). Leipzig: Engelmann.

Pax, F. \& Hoffmann, K. 1931. Crotoneae. Pp. 83-88 in: Engler, A. \& Prantl, K. (eds.), Die natürlichen Pflanzenfamilien, ed. 2, vol. 19c. Leipzig: Engelmann.

Posada, D. \& Crandall, K.A. 1998. MODELTEST: Testing the model of DNA substitution. Bioinformatics 14: 817-818.
Pursh, F.T. 1814. Flora Americae septentrionalis. London: printed for White, Cochranc, and Co.

Qiu, Y.-L., Li, L., Hendry, T.A., Li, R., Taylor, D.W., Issa, M.J., Ronen, A.J., Vekaria, M.L. \& White, A.M. 2006. Reconstructing the basal angiosperm phylogeny: Evaluating information content of the mitochondrial genes. Taxon 55: 837-856.

Rambaut, A. \& Drummond, A.J. 2007. Tracer. Version 1.5. http://tree .bio.ed.ac.uk/software/tracer/.

Riina, R. 2006. Molecular systematics of the Neotropical Dragon's Blood trees Croton sect. Cyclostigma (Euphorbiaceae). Dissertation, University of Wisconsin, Madison, U.S.A.

Riina, R. \& Berry, P.E. 2010. Two new South American species of Croton (Euphorbiaceae) and their phylogenetic affinities. Anales Jard. Bot. Madrid 67: 23-27.

Riina, R., Berry, P.E. \& Van Ee, B.W. 2009. Molecular phylogenetics of the dragon's blood Croton section Cyclostigma (Euphorbiaceae): A polyphyletic assemblage unraveled. Syst. Bot. 34: 360-374.

Riina, R., Cordeiro, I., Amorim, A. \& Berry, P.E. 2010a. Croton thomasii Riina \& P.E. Berry (Euphorbiaceae), a new species from the Atlantic Forest in the State of Bahia (Brazil) and typification of Croton sapiifolius Müll. Arg. Candollea 65: 101-107.

Riina, R., Van Ee, B., Wiedenhoeft, A.C., Cardozo, A. \& Berry, P.E. 2010b. Sectional rearrangement of arborescent clades of Croton (Euphorbiaceae) in South America: Evolution of arillate seeds and a new species, Croton domatifer. Taxon 59: 1147-1160.

Ronquist, F. 2004. Bayesian inference of character evolution. Trends Ecol. Evol. 19: 475-481.

Ronquist, F. \& Huelsenbeck, J.P. 2003. MrBayes 3: Bayesian phylogenetic inference under mixed models. Bioinformatics 19: 1572-1574.

Salatino, A., Salatino, M.L.F. \& Negri, G. 2007. Traditional uses, chemistry and pharmacology of Croton species (Euphorbiaceae). J. Brazil. Chem. Soc. 18: 11-33.

Secco, R.S., Berry, P.E. \& Rosa, N.A. 2001. Croton diasii and Croton trombetensis, two new Euphorbiaceae from Amazonian Brazil. Novon 11: 119-123.

Small, J.K. 1913. Croton. Pp. 454-455 in: Britton, N.L. \& Brown, A. (eds.), An illustrated flora of the Northern United States, ed. 2, vol. 2. New York: Charles Scribner's Sons.

Smith, B.A. 2002. A systematic revision of Croton section Cyclostigma (Euphorbiaceae) in Ecuador. Dissertation, University of California, Davis, U.S.A.

Smith, S.A. \& Donoghue, M.J. 2008. Rates of molecular evolution are linked to life history in flowering plants. Science 322: 86-89.

Städler, T. \& Delph, L.F. 2002. Ancient mitochondrial haplotypes and evidence for intragenic recombination in a gynodioecious plant. Proc. Natl. Acad. Sci. U.S.A. 99: 11730-11735.

Taberlet, P., Gielly, L., Pautou, G. \& Bouvet, J. 1991. Universal primers for amplification of three non-coding regions of chloroplast DNA. Pl. Molec. Biol. 17: 1105-1109.

Urbatsch, L.E., Baldwin, B.G. \& Donoghue, M.J. 2000. Phylogeny of the coneflowers and relatives (Heliantheae: Asteraceae) based on nuclear rDNA internal transcribed spacer (ITS) sequences and chloroplast DNA restriction site data. Syst. Bot. 25: 539-565.

Van Ee, B.W. 2006. Molecular phylogenetics within Croton (Euphorbiaceae s.s.). Dissertation, University of Wisconsin, Madison, U.S.A

Van Ee, B.W. \& Berry, P.E. 2009a. A phylogenetic and taxonomic review of Croton (Euphorbiaceae s.s.) on Jamaica including the description of Croton jamaicensis, a new species of section Eluteria. Syst. Bot. 34: 129-140.

Van Ee, B.W. \& Berry, P.E. 2009b. The circumscription of Croton section Crotonopsis (Euphorbiaceae), a North American endemic. Harvard Pap. Bot. 14: 61-70.

Van Ee, B.W. \& Berry, P.E. 2010a. Taxonomy and phylogeny of Croton section Heptallon (Euphorbiaceae). Syst. Bot. 35: 151-167.

Van Ee, B.W. \& Berry, P.E. 2010b. Typification notes for Croton (Euphorbiaceae). Harvard Pap. Bot. 15: 73-84.

Van Ee, B.W. \& Berry, P.E. 2011. Croton section Pedicellati 
(Euphorbiaceae), a novel New World group, and a new subsectional classification of Croton section Lamprocroton. Syst. Bot. 36: 88-98.

Van Ee, B.W., Berry, P.E., Riina, R. \& Gutiérrez Amaro, J.E. 2008. Molecular phylogenetics and biogeography of the Caribbean-centered Croton subgenus Moacroton (Euphorbiaceae s.s.). Bot. Rev. (Lancaster) 74: 132-165.

Van Ee, B., Jelinski, N., Berry, P.E. \& Hipp, A.L. 2006. Phylogeny and biogeography of Croton alabamensis (Euphorbiaceae), a rare shrub from Texas and Alabama, using DNA sequence and AFLP data. Molec. Ecol. 15: 2735-2751.

Webster, G.L. 1967. The genera of Euphorbiaceae in the southeastern United States. J. Arnold Arbor. 48: 303-430.

Webster, G.L. 1988. A new species of Croton (Euphorbiaceae) from Nicaragua. Madroño 35: 117-120.

Webster, G.L. 1993. A provisional synopsis of the sections of the genus Croton L. (Euphorbiaceae). Taxon 42: 793-823.

Webster, G.L. 2001. Synopsis of Croton and Phyllanthus (Euphorbiaceae) in western tropical Mexico. Contr. Univ. Michigan Herb. 23: $353-388$.

Webster, G.L. 2005. A new Mexican species of Croton section Eluteria (Euphorbiaceae). Lundellia 8: 12-16.

Webster, G.L. \& Huft, M. 1988. Revised synopsis of Panamanian Euphorbiaceae. Ann. Missouri Bot. Gard. 75: 1087-1144.

White, T.J., Bruns, T., Lee, S. \& Taylor, J. 1990. Amplification and direct sequencing of fungal ribosomal RNA genes for phylogenetics. Pp. 315-322 in: Innis M.A., Gelfand D.H., Sninsky J.J. \& White T.J. (eds.), PCR protocols: A guide to methods and applications. San Diego: Academic Press.

Wiedenhoeft, A.C., Riina, R. \& Berry, P.E. 2009. "Ray-intrusive" laticifers in species of Croton section Cyclostigma (Euphorbiaceae). I.A.W.A. J. 30: 135-148.

World Checklist of Selected Plant Families. 2010 - (continuously updated). The Board of Trustees of the Royal Botanic Gardens, Kew. Published on the Internet at http://www.kew.org/wcsp/ (accessed 28 September 2010).

Wurdack, K.J. 2006. The lectotypification and 19th century history of Croton alabamensis (Euphorbiaceae s.s.). Sida 22: 469-484.

Wurdack, K.J. \& Davis, C.C. 2009. Malpighiales phylogenetics: Gaining ground on one of the most recalcitrant clades in the angiosperm tree of life. Amer. J. Bot. 96: 1551-1570.

Wurdack, K.J., Hoffmann, P. \& Chase, M. 2005. Molecular phylogenetic analysis of uniovulate Euphorbiaceae (Euphorbiaceae sensu stricto) using plastid $r b c L$ and $t r n L-F$ DNA sequences. Amer. $J$. Bot. 92: 1397-1420.

Zwickl, D.J. 2006. Genetic algorithm approaches for the phylogenetic analysis of large biological sequence datasets under the maximum likelihood criterion. Dissertation, University of Texas at Austin, U.S.A.

Appendix. Taxa, localities, vouchers, and GenBank accession numbers for all sequences analyzed.

Taxon; locality; voucher; rps3; EMB2765 exon 9; ITS; trnL-F. Missing data:-.

Outgroup: Acidocroton trichophyllus Urb.; Cuba, Holguín; HAJB 81844 (MICH); HM564101; HM564234; EF421766; EF408087. Astraea klotzschii Didr.; Brazil, Bahia; Van Ee 484 (WIS); HM564102; HM564235; HM564073; HM564209. A. lobata (L.) Klotzsch; Cuba, Havana; HAJB 81999 (MICH); HM564103; HM564236; -; -. Costa Rica, Guanacaste; Van Ee 296 (WIS); -; -; EF421720; EF408089. Brasilicroton mamoninha P.E. Berry \& Cordeiro; Brazil, Espírito Santo; Pirani 3411 (NY); HM564104; HM564237; AY971175; AY971267.

Ingroup: Croton adenophyllus Bertero ex Spreng.; Jamaica, St. Andrews; Van Ee \& al. 770 (A); HM564105; HM564238; EU497728; EU497700. C. alabamensis E.A. Sm. ex Chapm.; U.S.A., Alabama; Van Ee \& al. 369 (WIS); HM564106; -; DQ227513; DQ227545. C. alainii B.W. van Ee \& P.E. Berry; Cuba, Holguín; HAJB 81770 (MICH); HM564107; HM564239; EF421756; EF408138. C. alamosanus Rose; Mexico, Sonora, Van Devender 2006-1284 (MICH); HM564108; HM564240; -; -. Mexico, Michoacán; Steinmann 1659 (WIS); -; -; EU477863; EU478123. C. andinus Müll. Arg.; Argentina, Catamarca; Van Ee \& al. 657 (US); HM564109; HM564241; FJ614761; FJ614801. C. argenteus L.; Costa Rica, Guanacaste; Van Ee 297 (WIS); HM564110; HM564242; EU478094; EU497702. C. argentinus Müll. Arg.; Argentina, Córdoba; Van Ee \& al. 638 (US); HM564111; HM564243; -; HM564210. Argentina, Córdoba; Van Ee \& al. 644 (US); -; -; EU497729; -. C. argyranthemus Michx.; U.S.A., Texas; Jones 8262 (MICH); HM564112; HM564244; HM564074; -. U.S.A., Texas; Fryxell 4967 (MO); -; -; -; HM564211. C. argyratus Blume; Malaysia, Selangor; Van Ee \& Sugumaran 790 (A); HM564113; HM564245; HM564075; HM564212. C. argyrophyllus Kunth; Brazil, Pernambuco; Carneiro-Torres 881 (SP); HM564114; HM564246; -; -. Brazil, Pernambuco; Van Ee 476 (WIS); -; -; HM564076; HM564213. C. astroites Dryand.; Puerto Rico; Van Ee 537 (WIS); HQ654591; HQ654592; EU586901; EU586955. C. atrostellatus V.W. Steinmann; Mexico, Michoacán; Steinmann 1681 (WIS); HM564115; -; EU477875; EU478124. C. billbergianus Müll. Arg.; Costa Rica, Alajuela; Van Ee \& Redden 342 (WIS); HM564116; HM564247; EU477998; EU478148. C. caracasanus Pittier; Venezuela, Distrito Federal; Riina 1288 (WIS); HM564117; HM564248; DQ227525; DQ227557. C. catamarcensis Ahumada; Argentina, Córdoba; Van Ee \& al. 653 (US); HM564118; HM564249; HM071949; HM071969. C. chamelensis E.J. Lott; Mexico, Guerrero; Moore \& Wood 4739 (A); HM564119; HM564250; FJ614707; FJ614775. C. cordiifolius Baill.; Brazil, Bahia; Queiroz 12041 (HUEFS); HM564120; HM564251; -; -. Brazil, Bahia; Thomas 13601 (CEPEC); -; -; EU586917; EU586971. C. coriaceus Kunth; Ecuador; Riina \& López 1403 (WIS); HM564121; HM564252; EU586921; EU586976. C. corinthius Poveda \& J.A.González; Costa Rica, Limón; Van Ee \& Van Ee 600 (WIS); HM564122; HM564253; EF421751; EF408110. C. coryi Croizat; U.S.A., Texas; Van Ee \& al. 520 (WIS); HM564123; HM564254; EU478012; EU478152. C. corylifolius Lam.; Jamaica, Manchester; Van Ee \& al. 775 (A); HM564124; HM564255; EU497734; EU497709. C. cuneatus Klotzsch; Peru; Riina 1491 (MICH); HM564125; HM564256; EU478005; EU497710. C. cupreatus Croizat; Ecuador, Pichincha; Smith 473 (WIS); HM564126; HM564257; HM564077; HM564214. C. curiosus Croizat; Argentina, Tucumán; Zuloaga 8438 (SI); HM564127; HM564258; EU586906; EU586960. C. dioicus Cav.; U.S.A., Texas; Yang 5 (MICH); HM564128; HM564259; HM564078; HM564215. C. discolor Willd.; Puerto Rico; Van Ee 547 (WIS); HM564129; HM564260; EU497736; EU497711. C. draco Schltdl. \& Cham.; Costa Rica; Van Ee \& Redden 347 (WIS); HM564130; HM564261; EU478006; EU497712. C. ekmanii Urb.; Cuba, Holguín; Van Ee 393 (WIS); -; HM564262; -; -. Cuba, Holguín; HAJB 81888 (MICH); HM564131; -; EF421763; EF408147. C. eichleri Müll. Arg.; Brazil, Rio de Janeiro; Riina \& Caruzo 1525 (SP); HM564132; HM564263; EU586949; EU587001. C. eremophilus Müll. Arg.; Brazil, Minas Gerais; Carneiro-Torres 707 (SP); HM564133; HM564264; HM564079; HM564216. C. flavens L.; Puerto Rico; Van Ee 540(WIS); HM564134; HM564265; EU477905; EU478134. C. floribundus Spreng.; Brazil, São Paulo; Berry 7686 (MICH); HM564135; HM564266; HM564080; -. C. fruticulosus Torr.; U.S.A., Texas; Van Ee \& al. 338 (WIS); HM564136; HM564267; EU477916; EU478136. C. fuscescens Spreng.; Brazil, São Paulo; Van Ee 502 (WIS); HM564137; HM564268; HM564081; HM564217. C. glabellus L.; Jamaica, St. Thomas; Van Ee \& al. 771 (A); HM564138; HM564269; EU477892; EU497719. C. glandulosepalus Millsp.; Belize, Cayo District; Vincent 6058 (MU); HM564139; -; EU477888; EU478126. C. glandulosus L.; U.S.A., Wisconsin; Van Ee \& al. 512 (WIS); HM564140; HM564270; EU478066; EU497713. C. gnaphalii Baill.; Argentina, Entre Ríos; Belgrano \& al. 423 (SI); HM564141; HM564271; EU586940; EU586994. C. goudotii Baill; Madagascar, Fianarantsoa; Hoffmann 248 (K); HM564142; HM564272; EU586946; EU587000. C. grisebachianus Müll. Arg.; Jamaica, St. Andrew; Van Ee \& al. 767 (A); -; HM564273; EU497737; EU497714. C. guildingii Griseb. subsp. tiarensis P.E. Berry \& Riina; Venezuela, Aragua; Riina 1274 (WIS); HM564143; HM564274; AY971254; AY971336. C. heterocalyx Baill.; Brazil, Bahia; Caruzo 108 (SP); HM564144; HM564275; HM044794; HM044775. C. hircinus Vent.; Venezuela, Distrito Federal; Riina 1291 (VEN); HM564145; -; EU477889; EU478127. C. hirtus L'Her.; Brazil, Pernambuco; Van Ee 481 (WIS); HM564146; HM564276; EU478071; EU497715. C. humilis L.; Jamaica, St. Andrews; Van Ee \& al. 769 (A); HM564147; HM564277; HM564083; HM564218. C. impressus Urb.; Puerto Rico; Van Ee 543 (WIS); HM564148; HM564278; EF421775; EF408113. C. jamaicensis B.W. van Ee \& P.E. Berry; Jamaica, St. Catherine; Van Ee \& al. 772 (A); -; HM564279; EU497733; EU497708. 
Appendix. Continued.

C. jimenezii Standl. \& Valerio; Costa Rica, San José; Van Ee 326 (WIS); HM564149; HM564280; EF421777; EF408115. C. lanatus Lam. var. tatacuensis (Ahumada) P.E. Berry; Argentina, Corrientes; Belgrano \& al. 256 (SI); HM564150; HM564281; HM564084; HM564219. C. laureltyanus Ahumada; Argentina, Corrientes; Belgrano \& al. 281 (SI); HM564151; HM564282; HM071953; HM071970. C. lechleri Müll. Arg.; Peru, San Martín; Riina \& Campos 1449 (WIS); HM564152; -; EU586927; EU586983. C. lechleri Müll. Arg.; Peru, San Martín; Riina 1497 (WIS); -; HQ654593; -; -. C. leonis (Croizat) Van Ee \& P.E. Berry; Cuba, Holguín; HAJB 81773 (MICH); HM564153; -; EF421758; EF408140. C. lepidotus Aug. DC.; Madagascar, Toamasina; Van Ee \& al. 998 (MICH); HM564154; HM564283; HM564085; HM564220. C. lindheimerianus Scheele; Mexico, Tamaulipas; Van Ee \& al. 521 (WIS); HM564155; HM564284; EU478111; EU478168. C. lindheimeri (Engelm. \& A.Gray) Alph.Wood; U.S.A., Louisiana; Van Ee \& al. 517 (WIS); HM564156; HM564285; EU478106; FJ614778. C. linearis Jacq.; Jamaica, St. James; Van Ee \& al. 745 (A); -; HM564286; -; -. Bahamas, Cat Island; Richey 99387 (MU); -; -; EU477933; EU478138. C. louvelii Leandri; Madagascar; Hoffmann 194 (K); HM564157; HM564287; HM564086; HM564221. C. lucidus L.; Jamaica; Manchester; Van Ee \& al. 776 (A); -; HM564288; EU497743; EU497726. C. luetzelburgii Pax \& K.Hoffm.; Brazil, Bahia; Conceição 1457 (HUEFS); HM564158; HM564289; HM564087; HM564222. C. lundellii Standl.; Mexico, Yucatán; Van Ee \& May-Pat 123 (WIS); HM564159; HM564290; EF421733; EF408099. C. maestrensis (Alain) B.W. van Ee \& P.E. Berry; Cuba, Granma; HAJB 81958 (MICH); HM564160; HM564291; EF421753; EF408127. C. matourensis Aubl.; Brazil, Amazonas; Van Ee 492 (WIS); HM564161; HM564292; EU478096; EU497720. C. megistocarpus J.A.González \& Poveda; Costa Rica, Puntarenas; Gardner s.n. (WIS); HM564162; HM564293; EF421779; EF408118. C. miarensis Leandri; Madagascar, Toliar; Van Ee \& al. 903 (MICH); HM564163; HM564294; HM564088; HM564223. C. micans Sw.; Dominica; Whitefoord 4449 (BM); HM564164; HM564295; -; -. Dominica; Hill 24051 (MO); -; -; EU497731; EU497705. C. michauxii G.L. Webster var. elliptica (Willd.) B.W. van Ee \& P.E. Berry; U.S.A., Missouri; Archer 40 (MO); HM564165; HM564296; EU478004; HM564224. U.S.A., Missouri; Cusick 33275 (MICH); HM564166; HM564297; HM564089; HM564225. C. milleri J.R. Johnst.; Venezuela, Nueva Esparta; Riina 1269 (WIS); HM564167; HM564298; AY971232; AY971319. C. minimus P.I. Forst.; Australia, Queensland; Forster 28146 (WIS); HM564168; HM564299; HM564090; -. C. monanthogynus Michx.; U.S.A., Illinois,; Van Ee \& al. 515 (WIS); HM564169; HM564300; EU478113; EU478169. C. morifolius Willd.; Costa Rica, Guanacaste; Van Ee 295 (WIS); HM564170; HM564301; EU477943; -. Costa Rica, Guanacaste; Van Ee 286 (WIS); -; -; -; EU478140. C. myricifolius Griseb.; Cuba, Havana; Van Ee 379 (WIS); HM564171; HM564302; HM564091; HM564226. C. nitens Sw.; Jamaica, St. James; Van Ee \& al. 744 (A); HM564172; HM564303; EU478042; EU497724. C. niveus Jacq.; Costa Rica, Heredia; Van Ee \& Van Ee 593 (WIS); HM564173; HM564304; EF421780; EF408119. C. nobilis Baill.; Madagascar, Toliar; Van Ee \& al. 938 (MICH); HM564174; HM564305; HM044797; HM044778. C. noronhae Baill.; Madagascar, Toamasina; Van Ee \& al. 1001 (MICH); HM564175; HM564306; HM564092; HM564227. C. nubigenus G.L. Webster; Nicaragua, Región Autónoma del Atlántico Norte; Van Ee \& Coronado 587 (HULE) [= Coronado \& al. 3404 (HULE, MO)]; HM564176; HM564307; EU478103; -. Nicaragua, Región Autónoma del Atlántico Norte; Van Ee \& Coronado 589 (HULE); -;-;-; EF408121. C. olivaceus Müll. Arg.; Ecuador, Napo; Neill 11163 (MO); HM564177; -; AY971237; AY794694. C. pachysepalus Griseb.; Cuba, Guantánamo; HAJB 81930 (MICH); HM564178; HM564308; HM071957; HM071974. C. pedicellatus Kunth; Colombia, Cundinamarca; Plowman 3766 (GH); HM564179; HM564309; FJ614766; FJ614804. C. peraeruginosus Croizat; Mexico, Yucatán; Van Ee 128 (WIS); HM564180; -; EU477953; EU478141. C. piptocalyx Müll. Arg.; Brazil, São Paulo; Caruzo 54 (SP); HM564186; HM564310; EF421791; EF408132. C. poecilanthus Urb.; Puerto Rico; Van Ee 551 (WIS); HM564181; HM564311; EF421782; EF408122. C. polyandrus Spreng; Brazil, Bahia; Nunes 1376 (HUEFS); HM564182; HM564312; -; HM564228. Brazil; Bahia; Cordeiro 3017 (SP); -; -; HM564093; -. C. priscus Croizat; Brazil, São Paulo; Riina 1535 (WIS); -; HQ654594; EU586950; EU587002. C. pulcher Müll. Arg.; Mexico, Oaxaca; Walker 3005 (WIS); HM564184, HM564314; EU477994; EU478147. C. punctatus Jacq.; Mexico, Veracruz; Van Ee \& al. 528 (WIS); HM564185; HM564315; EU478022; EU478153. C. roraimensis Croizat; Venezuela, Bolívar; Riina 1539 (VEN); HM564187; HM564316; HM564094; EF408149. C. salutaris Casar.; Brazil, Rio de Janeiro; Caruzo 89 (SP); HM564188; HM564317; HM044804; HM044783. C. sampatik Müll. Arg.; Perú, Pasco; Riina 1447 (WIS); HM564189; HM585372; EF421792; EF408133. C. sapiifolius Müll. Arg.; Brazil, Bahia; Lima 677 (CEPEC); HM564190; -; EF421754; EF408150. C. schiedeanus Schltdl.; Mexico, Yucatán; Van Ee 458(WIS); HM564191; HM564318; EU478051; EU478156. C. sellowii Baill.; Brazil, Bahia; Van Ee 498 (WIS); HM564192; HM564319; HM564095; HM564230. C. serratifolius Baill,; Argentina, Córdoba; Van Ee \& al. 639 (US); HM564193; HM564320; HM564096; HM564231. C. setiger Hook.; U.S.A., California; Berry 7688 (WIS); HM564194; HM564321; HM564097; -. California; Hughey s.n. (US); -; -; -; AY794697. C. skutchii Standl.; Costa Rica, Cartago; Van Ee \& Van Ee 597 (WIS); HM564195; HM564322; EU478100; EU478166. C. smithianus Croizat; Costa Rica, Heredia; Van Ee s.n. (A); HM564196; HM564323; HM564098; -. C. speciosus Müll. Arg.; Venezuela, Distrito Federal; Berry 7590 (WIS); HM564197; HM564324; AY971251; AY794699. C. tenuilobus S. Watson; Mexico, Sonora; Van Devender \& al. 2006-993 (MICH); HM564198; -; -; -. Mexico, Jalisco; Webster \& Lynch 17169 (GH); -; HM564325; FJ614764; FJ614803. C. thomasii Riina \& P. E. Berry; Brazil, Bahia; Lima 654 (CEPEC); HM564201; HM564327; EU586951; EU587003. C. trinitatis Millsp.; Brazil, Amazonas; Van Ee 507 (WIS); HM564199; -; EU478092; HM564232. C. triqueter Lam.; Brazil, São Paulo; Caruzo 27 (SP); HM564200; HM564326; -; -. Bolivia, Santa Cruz; Nee 40034 (NY); -; -; AY971256; AY794700. C. urucurana Baill.; Brazil, São Paulo; Amaral 2002-09 (UEC); HM564202; -; -; -. Brazil, Minas Gerais; Riina \& al. 1317 (MICH); -; HQ654595; EU586937; EU586991. C. warmingii Müll. Arg.; Brazil, São Paulo; Caruzo 56 (SP); HM564203; -; EU586915; EU586970. C. watsonii Standl.; Mexico, Tamaulipas; Dwyer \& al. 90 (GH); HM564204; -; HM564099; HM564233. C. yavitensis Croizat; Bolivia, Beni; Beck 5710 (LPB); HM564205; HM564328; EU586918; EU586918. C. ynesae Croizat; Mexico, Nayarit; Webster \& Breckon 15774 (GH); HM564206; HM564329; HM564100; -. C. yucatanensis Lundell; Mexico, Yucatán; Van Ee \& May-Pat 121 (WIS); HM564207; HM564330; DQ227537; DQ227569. C. zambesicus Müll. Arg.; Zambia, Songwe Gorge; Zimba \& al. 901 (MO); HM564208; HM564331; AY971260; AY971341. 